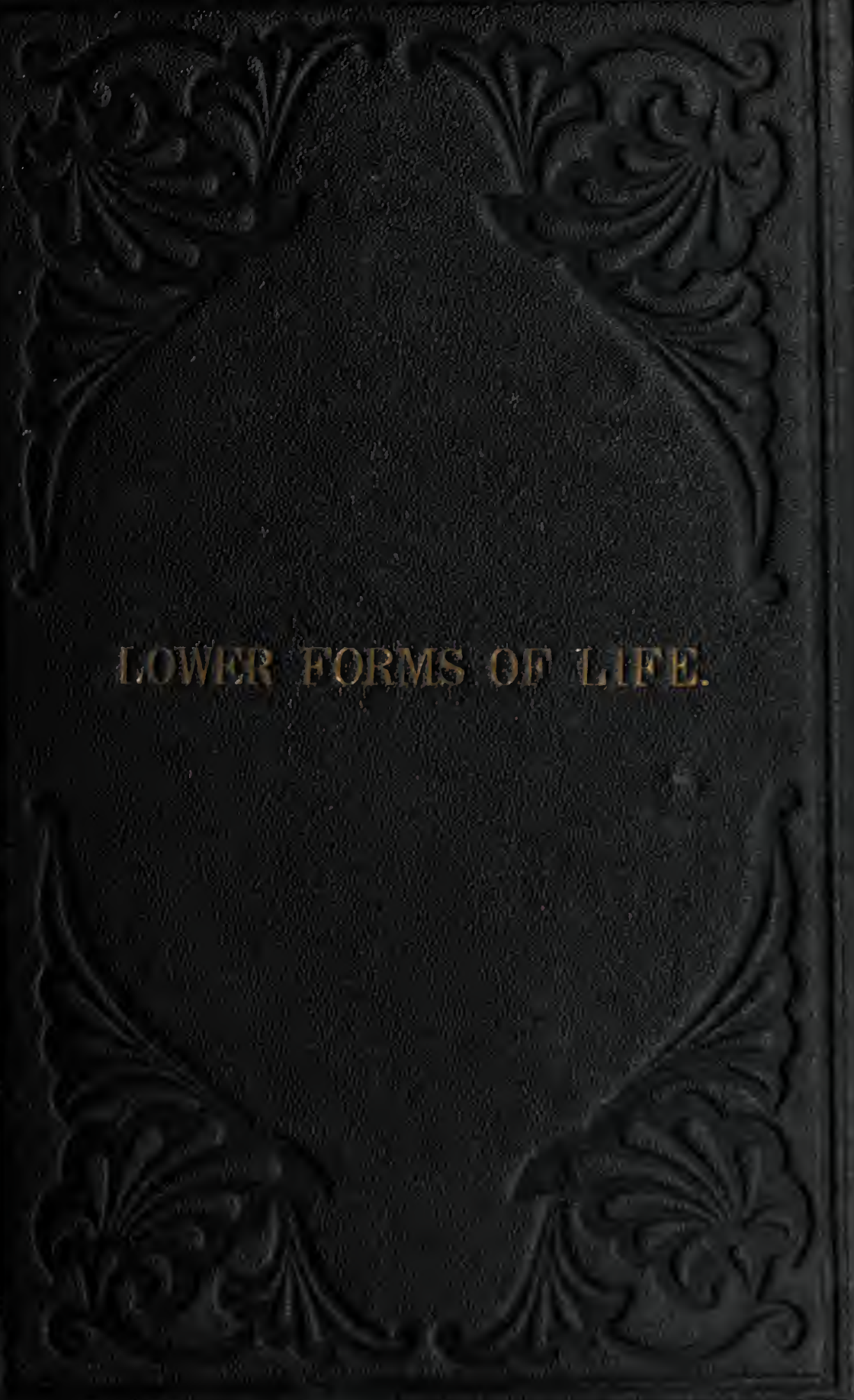


"A very merit

"The woodcut:

"A useful refe

\section{Library}

of the

In post 8vo FACTS and U I being a coll greatest utility tc on the Managem

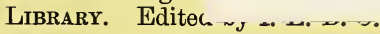

ted by "STONE-

- Bell's Life.

id EDition of

and SHOOTING; lescriptions, of the a Series of Recipes I. of "The FiELD."

In post 8 vo, uniform with the above, price $5 s$., the SECond Edrrion, Revised and Enlarged, of

I JHE COUNTRY HOUSE: a Collection of Useful Information and Recipes 1 adapted to the Country Gentleman and his household, and of the greatest utility to the housekeeper generally. Vol. II. of "THE FIELD" Library. Edited by I. E. B. C.

In post $8 \mathrm{vo}$, uniform with the above, price $5 s$,

' I'HE FARM, GARDEN, STABLE, and AVIARY: to which is added some Useful Information relating to the Poultry-yard, Bee-keeping, and Natural History : being specially valuable to Country Gentlemen, Farmers, Gardeners, and those interested in the Preservation of Birds, Beasts, or Fishes. Vol. III. of "The Field" Library. Edited by I. E. B. C.

In post 8 vo, uniform with the above, price $5 s$,

THE YEAR OF LIBERTY; or, Salmon Angling in Ireland, from Feb. 1 to 1 Nov. 1. By WILLIAM PEARD, Esq., M.D., LL.B. Vol. IV. of "The FiELd" Library.

In demy 8 vo, cloth gilt, price $2 s .6 d$,

THE SILKWORM BOOK; or, SILKWORMS ANCIENT and MODERN, 1 their Food and Mode of Management. By W. B. LorD, R.A., Author of "Sea Fish, and How to Catch Them," \&c.

This work treats of all the known kinds of silk-producing worms, the food that should be given them, and the way they should be managed.

It is illustrated with engravings of the caterpillar, moth, and cocoon of the oak-leaf silkworm (the Yama mai), the Ailanthus, and the apparatus used in the management of the worms and in the preparation and winding off of the silk from the cocoons.

In post 8 vo, limp cloth gilt, price $2 s .6 d$; post free, $2 s .8 d$.,

THE ART of SKATING, containing many figures never previously described; with Illustrations, Diagrams and plain Directions for the acquirement of the most difficult and elegant movements. By GEORGE ANDERSON ("Cyclos"), for many years President of the Glasgow Skating Club.

\section{In small 8vo, cloth gilt, price $4 s$,}

'THE ARTS of ROWING and TRAINING, by "ARGONAUT," comprising Full and Complete Instructions on Learning to Row, on the Physical Preparation of Oarsmen and Scullers, and on the Management of Regattas; together with an Appendix containing the Laws of Boat-racing, Qualification, \&c.

"A praiseworthy advance upon an antique system."-Reader.

"Whatever can be done by printed directions, 'Argonaut' has done very fairly."-Saturday Review. 
Digitized by the Internet Archive in 2017 with funding from University of Toronto 
<smiles>C1=CC=C1</smiles> 


\section{POPULAR ILLUSTRATIONS}

OF THE

\section{LOWER FORMS OF LIFE.}





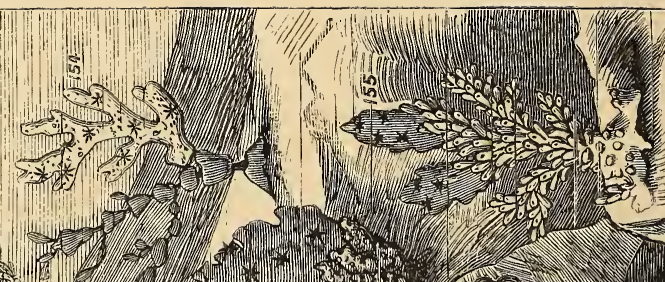

(2)

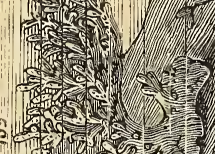

(1)

1.

2. (1)

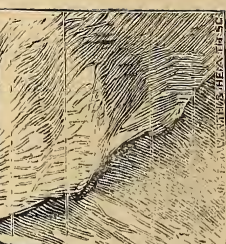

要

สิตี

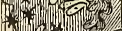

(5)

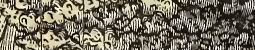

(1)

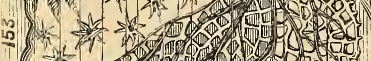

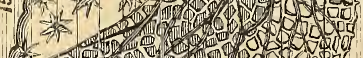

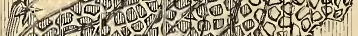
1. ¿c.

rom

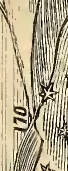

(1)

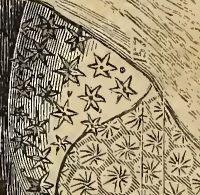

2.5. 15 .

a.s.

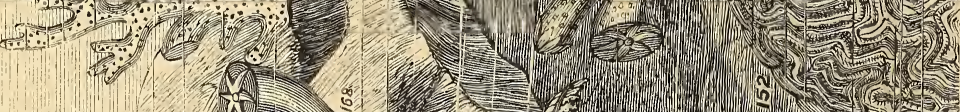

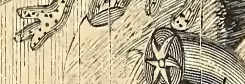

a)

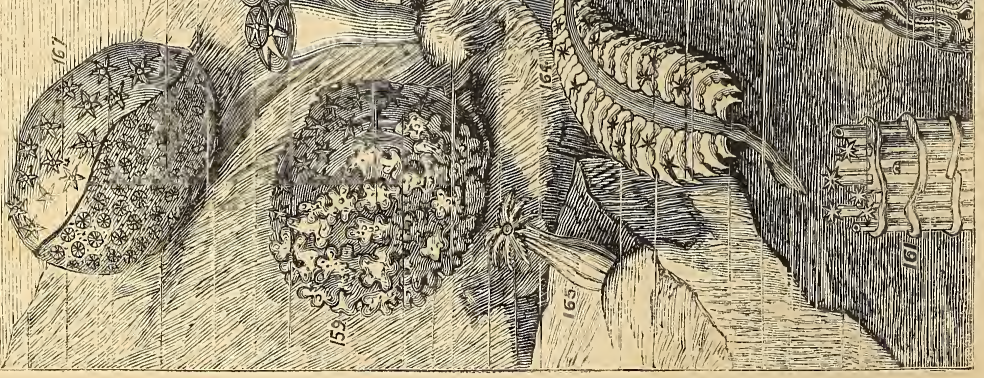

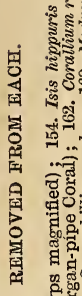

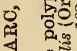

ชी

पू है

영 혼

द्रींके

EN

대럴.

4i.

ซृ. ․․

हैะ

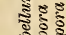

볼



要

क्न

궁

엉즐

쿅

島

4 我

हैं०

है휴

ธิ้ 혜

हैं

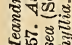

ํำ

Tร

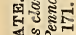

ㄷำ

ह1에

(1)

政

ㅎํㄴ

ג田裙 


\title{
POPULAR ILLUSTRATIONS
}

OF THE

\section{LOWER FORMS OF LIFE:}

COMPRISING

\begin{abstract}
I.-THE PROTOPHYTON.
II.-THE PROTOZOON.

III.THE COELENTERATA.
\end{abstract}

C. R. BREE, M.D., F.L.S., F.Z.S.,

Semion. Physician to the Essex and Culchester Hospital.

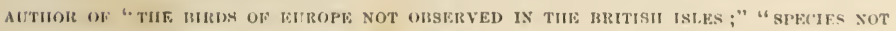

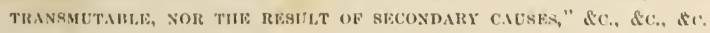

LONDON :

MORACE COX, 3.6, S'TRANH, W. 
LONDON :

PRINTED BY HORACE COX, STRAND, W.C. 


\section{PREFACE.}

THE following pages were published in a series of articles in the Field newspaper, with the object of making the study of Natural History more intelligible to the general public than a more rigid adherence to scientific systematic writing would have done. While endeavouring, however, to popularise the subject, I have taken especial care not to degrade it by sacrificing truth to what may be called sensational science. My object has been rather to prepare the mind for deeper delving in the rich mines than to make it content with any glittering specimen it may meet with on the surface. The subject is thereforo necessarily incomplete, even as to a thorough examination of the three great divisions of Nature with which I have dealt. But I have endeavoured to bring out all their salient points, and have, I trust, succeeded in making them clear and intelligible. While expressing my opinion with perfect freedon and independence,

1. have avoided controversy as much as possible. There are many means open to the student in which he may study with advantage the two great lines of thought by which the primary or secondary character of species are adrocated.

The great book of Naturo will always be interpreted differently so long as the human mind differs in its powers of thought and reflection.

But the student will best preparm himself to decide rightly an this subjoet by a careful study of facts. I believe this will leat 
him to a belief in the adaptation of every part of organised structure to its special use by the preconceived design of a Divine Architect, rather than to that cold and unimaginative doctrine which views all nature as the result of secondary laws which subserve to "arrested development," "natural selection," or the "struggle for existence." I do not say this in any spirit of detraction; for I know that some of our ablest and most zealous workers hold views to which the last remark will apply. But there is plenty of room in the field of scientific research for the greatest diversity of opinion. The problem of the "origin of species" will, in all probability, never be unfolded to the human intellect; for, carry back the imagination from the highest to the humblest organic form, still the "incoming" of the latter is as great a mystery as ever. The FINITE cannot comprehend the INFINITE mind.

Should this volume be received favourably, I shall be encouraged to go "onward" in the scale, and finish in another (the Invertebrate) class of animal life.

Colchester, April 20, 1868. 


\section{CO O T E NTS.}

\section{PAR'T I.-THE PRO'IOPHYTON.}

CHAPTER I.

The Natural History of a Grain of Wheat $\quad \ldots \quad \ldots \quad \ldots l$ page $1-7$

CHAPTER II.

The Natural History of a Grain of Wheat (continued) $\quad \ldots \quad \ldots \quad 7-12$

CHAPTER III.

Tho Natural History of a Grain of Wheat (concluded) $\quad \ldots \quad \ldots \quad 12-18$

\section{PAR'T II.-THE PROTOZOON.}

\section{CHAPTER I.}

The Protozoa: The Grogarina and Infusoria

CHAPTER II.

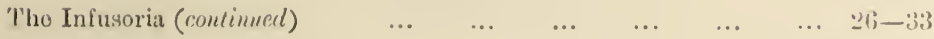

CHAPTER III.

'T'ho Rhizopodit

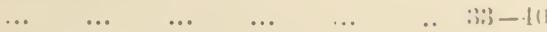

CHAPTELIV.

The Rhiropodia (continnerl) - Tho For:aninifera

CHAPTER V.

The Foraminifera in T'mo 


\section{PART III.-THE CGLLENTERATA.}

CHAPTER I.

$\begin{array}{llllllllll}\text { The Hydrozoa } & \ldots & \ldots & \ldots & \ldots & \ldots & \ldots & \ldots & \text { page } & 69-78\end{array}$

CHAPTER II.

The Hydrozoa (continued) - The Calycophoridæ $\quad \ldots \quad$.. $\quad \ldots \quad 78-86$

CHAPTER III.

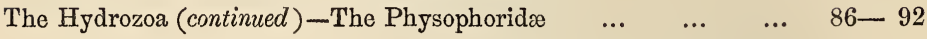

CHAPTER IV.

$\begin{array}{lllllllllll}\text { The Medusidæ } & \ldots & \ldots & \ldots & \ldots & \ldots & \ldots & \ldots & \ldots & 92-99\end{array}$

CHAPTER V.

Phosphorescence of the Sea-Reproduction of the Hydrozoa $\quad . .99-105$ CHAPTER VI.

$\begin{array}{lllllllllll}\text { The Actinozoa } & \ldots & \ldots & \ldots & \ldots & \ldots & \ldots & \ldots & \ldots & 105-110\end{array}$

CHAPTER VII.

$\begin{array}{llllllllllll}\text { Coral } & \ldots & \ldots & \ldots & \ldots & \ldots & \ldots & \ldots & \ldots & \ldots & 111-117\end{array}$

CHAPTER VIII.

$\begin{array}{llllllllll}\text { Coral }(\text { continued }) & \ldots & \ldots & \ldots & \ldots & \ldots & \ldots & \ldots & 117-122\end{array}$

CHAPTER IX.

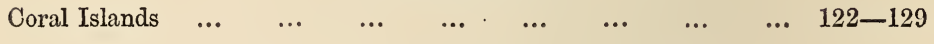




\section{POPULAR ILLUSTRATIONS}

OF TIF:

\section{LOWER FORMS OF LIFE.}

\section{PART I.}

\section{THE PROTOPHYTON.}

\section{CHAPTER I.}

I PROpose to offer a series of chapters on the various phases of organic life, commencing with the lowest form of vegetable structure, and ascending in the scale upwards.

I hope to make these illustrations both interesting and instructive. I shall endeavour to present the inner pages of the great book of nature in a form which will be readily understood by all classes of readers.

'Thus, while they may enjoy that true delight by means of their senses, which is afforded by looking at beautiful scenery, or watching the habits of the creatures by which it is peopled, I shall not, I think, be asking too much in calling upon them to go a step further, and to follow me in the intellectual investigation of organic structure, its uses, and its adaptations to the purposes for which living things were created.

With these remarks, I proceed to ask-What is the Protophyton?

It is the type of the ultimate structure of plants, and before we study the animal organisation it is necessary to have a just coneeption of that of the vegetable. The protophyton is a simple cell, only seen through the microseope, entaining a fhid and having a nuelens, and what are ealled cell-walls.

In its simplest form, as sern in the fungus which appears in rast districts on the surface of snow, and known as red snow, this cell constitutes the entire plant. Tho protophyten is distinguished from the protozoon, which is the typo of animal structure, in the important fact that it absorbs carbonic acid gas from the atmosphere, 
and emits oxygen ; while the latter emits carbonic acid and absorbs oxygen. They may be diagrammatically represented in the following figures :

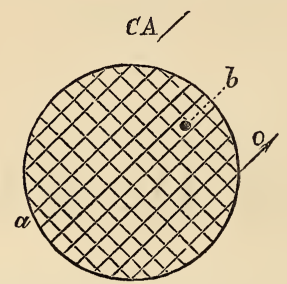

Proto-phyton (from $\mathrm{I} \varrho \tilde{\omega} \tau$ \%s, first, and $\Phi v \tau^{\prime} v$, a plant).

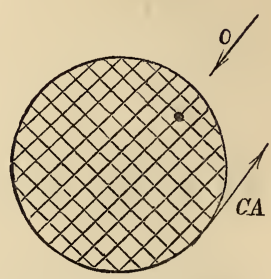

Proto-zoon (from $\Pi \rho \tilde{\omega} \tau<s$,

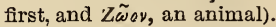

These cells are of all shapes, seldom so round as represented in the diagram. They essentially consist of what are termed cell-walls, having one or two layers (a), and of cell contents, which are a fluid represented by the cross-lines; small particles of matter termed molecules or granules, held in solution by the fluid; and a nucleus $(b)$, which often contains a still smaller body, termed the nucleolus. Now, these cells exist as separate and distinct beings-living, reproducing, and occupying very important positions in the economy of nature. From these cells all living structures, vegetable or animal, are built up.

It is the Protophyton which will for the present engage our attention; and I propose to illustrate its development in the vegetable world by describing

\section{The Natural History of a Grain of Wheat.}

I will commence my history with the grain as it is stored up in the barn of the farmer, or rather just as he is going to plant it in the autumn. If the seed is examined, a small whitish spot will be noticed on the lower part of the back. This is the germ of the future plant, which if placed under certain circumstances will have its dormant life called into action, and will begin to grow.

Now in the very threshold of our inquiry we see a most beautiful provision, and are met with a very perplexing question-What is life? This question has puzzled wiser heads than my own. It cannot, in fact, be answered. And why? Simply because the mind of man is finite, and life is one of the attributes of Infinity. We have nothing with which we can compare it, and therefore as man's reason essentially depends upon the power of comparison, we cannot nor ever will solve the difficulty.

There has been a tendency in the discussions of recent days to identify the vital with the physical forces of attraction, as evinced in 
chemical combinations, or electricity, or heat; but such reasoners make no real progress in the inquiry. Life is the great antagonistie principle to ehemical forees, and hence arises an insurmountable difficulty in proving that one is a correlation of the other. Electricity may be a correlation of heat, because they ean, it is said, be converted into each other. Neither of them, however, will give life to an inanimate or unorganised body.

And so it arises that there is great beauty in the provision which is fore-ordained that the life of the organised grain of wheat should remain dormant until the eircumstances necessary for its existence as a living thing are presented to it. These circumstances are the united presence of heat, moisture, and atmospheric air. This dormant condition of the seed is therefore one of the attributes of life. That the life, though dormant, is really a powerfui foree is proved by the fact that it prevents the eonstituents of the seed from being subject to the chemieal forces which decompose and re-arrange the elements of dead matter. So long as the above conditionsheat, moisture, air-are kept away from the seed, its vitality will lie dormant, and its physical eondition remain unaltered for any length of time that the imagination can depiet.

But the wheat-seed has a great and important offiee to fulfil in the world. Its destiny is more or less connected with that of the whole human race. It is the means by which that daily prayer, "Give us this day our daily bread," is answered, and due provision made that it should perform the duties for which it was created. Brought under the united influenee of heat, moisture, and atmospheric air, all of whieh it meets with in the soil, we see a very beautiful process - the seed germinates.

Now let us for a moment examine Fig. 2, which represents a longitudinal section of a grain of wheat, with the parts of the germ or embryo enlarged (after Henslow).

First observe the two skins or coverings, one (a) is called in botanical

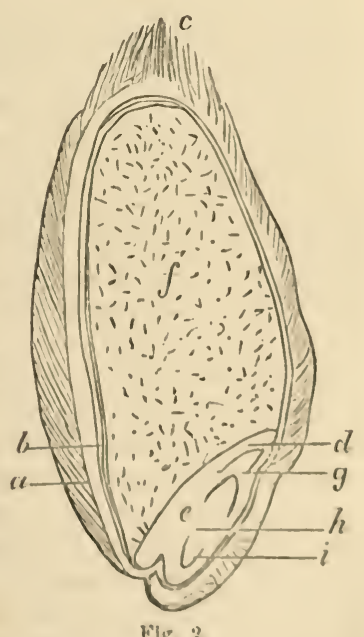

Flg. 2. language the "pericarp" or onter skin, and (b) the "endocarp " or integument or imer skin. These skins are well known to millers, for the thinner they are the more flour and less hran is yielded to the grimestones. At the top of the section (c) is the B. 2 
beard, and at the bottom (e) is the embryo or germ, while $(f)$ represents the flour of the grain, or, as it is called botanically, the albumen of the seed.

Let us examine the embryo more particularly. As it lies in the seed it can readily be divided into four portions. An upper portion $(d)$, which is the young seed leaf or cotyledon, is single, and therefore the class of plants to which the wheat belongs is called "monocotyledonous." The second portion of the embryo $(g)$ represents the plumule or bud of the plant, while that part marked $(i)$ represents the root or radicle, and the portion between the radicle and plumule marked $(h)$ represents the stem. The embryo is, in fact, to all intents and purposes a young plant, which, like young people, requires a start in life. And this start is given to it by a conjunction of the "circumstances necessary for its existence," which, as before stated, are heat, moisture, and air.

All the summer the soils of our fields are absorbing heat directly from the sun and stars. Heat is a force and principle in nature which has many most interesting properties, for a description of which I must refer to works on natural philosophy. Water is formed by the chemical union of two gases (hydrogen and oxygen), which are elementary principles in nature, and, like all other chemical compounds, they unite to form water in fixed and definite proportions. By volume this union is as 2 of hydrogen to 1 of oxygen, the size of an atom of hydrogen being double that of oxygen. By weight the proportions are, hydrogen 1 , and oxygen 8 - the latter atom being eight times heavier than that of the former; and the combining proportion of water when it unites chemically with other bodies, as it does with sulphuric acid, is 9 . Atmospheric air is a mechanical mixture of two gases and a solid body-three elementary principles of nature. These are-nitrogen (an element which enters largely into the composition of animal structures), oxygen, and carbon. The first two are in the proportion of nitrogen 79 and oxygen 21 parts, less the 1000th part, which is occupied by a union of carbon and oxygen forming carbonic acid-a most important part, as we shall see, of the food of plants.

Let us now proceed to notice what takes place when the seed is brought into contact with heat, moisture, and atmospheric air. First, the embryo plant begins to grow ; the dormant life springs into action; the bud, enveloped or surrounded by its cotyledon or seed leaf, appears above the ground, while the radicle or root makes a similar movement into the ground below.

Let us linger a moment and inquire what is meant by "growth."

The embryo is originally a cell, known as pollen grain, containing molecular matter, that is, matter having the greatest amount of 
division known to the highest power of our microscopes. How this pollen grain gets into the seed I will show by and by. But the embryo now must be considered as an aggregate of four protophytic cells, containing an albuminous or nitrogenous fluid (similar somewhat in its properties to white of egg), molecular matter, and a nucleus. Now, each of the four cells, the embryo cotyledon, plumule, caulicle, and radicle (Fig. 2, p. 3), multiply, and so each organ grows. But this growth requires new matter to be supplied, so that the vital powers of the cell can then form new material. In other words, the young cells require feeding. Helpless as a newborn babe without a mother would be that young embyro plant unless wiso forethought had made provision to meet its necessities. As yet, the young plant cannot help itself. Its roots and leaves are unformed. Just, however, as milk is provided for a helpless babe, so is food provided for the helpless plant. That food is the flour which, when the seed is ground, makes our bread. It is the albumen of the seed ( $f$, Fig. 2, p. 3). But the plant, whether in its embryonic or matured condition, can only take in food in a fluid or aerial condition. Now, the flour of the wheat-seed is not easily soluble, at least, not so as to be taken up by a tender organism like our wheat-plant. How is this difficulty overcome?

Nothing in nature is more striking and beautiful than the answer to this question. If the flour of the wheat-seed were more soluble it would be spoiled when subjected to wet; it would not keep in our granaries, and its use as human food would be lost to mankind. When subjected, however, to moisture, heat, and atmospheric air, the flour is chemically decomposed, and the starch which it contains is converted into sugar, which is soluble, and in that condition can bo taken up as food by tho embryonic plant. To understand this clearly, a word or two must be said about the chemical constitution of a grain of wheat.

It consists of organic or regetable, and inorganic or mineral substances. The vegetable are starch and gluten; the mineral, phosphorus, lime, iron, magnesium, sodium, potassium, silica, and sulphur. Thero aro also certain gases-chlorine, oxygen, carbon, hydrogen, and nitrogen.

To avoid confusing the non-chemical reader. I will confine myself for the present to the chemistry of the change which is undergone by the flour of the grain during germination.

Starch, of which the best wheat-flour contains from 60 to $66^{\circ}$ per cent., is thus composed - in atoms:

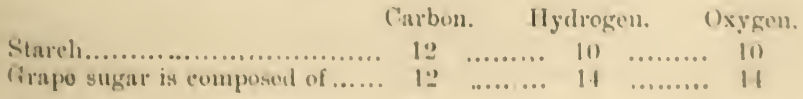


It will be seen that to convert starch into sugar, it is only necessary to add four atoms of hydrogen and four of oxygen. How is this obtained? Why, as I have before remarked, one of the conditions of germination is the presence of moisture or water, which is composed of hydrogen and oxygen. Under the influence, then, of this vital force-of that mysterious power we term "life" - this wonderful change is effected which enables the young plant to feed.

But what becomes of the gluten of the flour? It is contained therein in the variable proportions of 12 to 20 per cent., and may easily be separated from the starch by making a portion of flour into paste with pure water, and then carefully washing it out on a fine cloth. The starch, as a milky solution, will pass through the cloth, leaving a greyish, elastic, insoluble substance behind, called gluten. Now, this "gluten" of wheat-flour is composed of a small proportion of a peculiar matter, to which its sticky or adhesive properties are due, called "gliadine," and a large proportion of a substance called "vegetable fibrine," which is identical, in chemical composition, with white of egg or "albumen," with the chief constituent of flesh or "animal fibrine," and with the chief constituent of milk or "caseine," all of which are essentially parts of animal bodies. The great difference between gluten and starch is owing to the presence in the former of rather more than one-sixth of its entire bulk of nitrogen, or as it is sometimes called "azote." If we wish to produce fermentation in the sweet, sugary wort of beer, we introduce what is called a ferment-viz., yeast. If we wish to convert our milk into cheese, we do so by introducing into it a piece of rennet, by which decomposition is effected. So, nature in the germination of the seed produces a ferment, through whose agency the starch is converted into sugar, and it is done in this wise. The gluten is decomposed, and is converted into what is called diastase, which acts in decomposing the starch just as the yeast does the sweet wort, or rennet with the milk. Gluten deprived of its gliadine is constituted in a hundred parts, as follows :

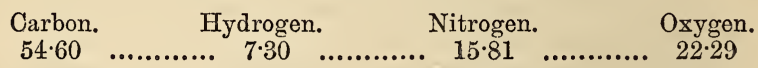

And by an interchange of these elements diastase is formed. This diastase alters the molecular arrangement of the starch, and changes it first into gum or dextrine, and then into grape sugar; during which process there is an evolution of carbonic acid from the excess of carbon and oxygen.

Such is the process by which the embryonic plant is provided in infancy with the means of subsistence. 
Now what does this process involve:-(1) The presence of the flour of the seed; (2) that this flour should be of such a constitution and consistency as to be able to resist the decomposing agencies around it, until it is called into use by the vital energies of the embryonic wheat-plant; and (3) that it should be so constituted chemically as to be easily converted into the soluble food requisite for the young plant.

But the plant though a living, is an unconscious being. Though it performs, it can have no share in the prospective issue involved in these processes. As reasoning creatures, we should do very much the same if we had the future of the wheat-plant to provide for. We could, however, only do this by the faculties which constitute our reason, that is, by comparing the experience of the past with the necessities of the future; but in this process of germination all is done without knowledge, feeling, sense, or reason, and we therefore, and of a necessity from which there is no escape, come to the conviction of the operation of a Great First Cause.

\section{CHAPTER II.}

\section{The Natural History of a Grain of Wheat (continued).}

HAving started our young plant in life it makes good use of its time, feeds upon the sugary food provided for it, and in due season the wheat-plant produces roots.

Every one knows what the root of a plant is, as it appears to the eyo. Comparatively speaking, few people know it as an organised structure.

The cell which forms the embryonic radicle (Fig. 2, p. 3) multiplies, and the root grows in the form of a minute filament or threadlike organ, which strikes down into the earth. This filament in the wheat-plant is repeated many times, each filament rising from what is called the axis (Fig. 3, p. 8). Now these cells multiply in at least three different ways.

lirst: They divile into two or more portions-each portion becoming a perfect cell, or one cell buds out, as it were, from another. and this mode of eell growth is callod exogenous, because the change occurs outwardly.

Secondly: Cells form within cells, and, the containing cell bursting, its numerous contents each assume the functions-as they possess the structure-of perfoct cells. This is called the endogenous formation of cells, the change taking place from within. 
Thirdly: The most important mode of cell-formation carries us a step beyond the cell. The ultimate form of matter, as shown by the highest power of the microscope, exists in atoms called molecules. Under favourable circumstances a group of these molecules form for themselves a covering, or cell-wall. This is called the molecular formation of cells.

Cells also unite together to form larger cells, and this has been designated the congregation method of increase, and is well exemplified in the growth of the lower forms of vegetable life.

Now cells increasing in one or other of these methods, and becoming united to each other, some of them forming elongated tubes, or, as they are called, vascular organs, and the whole surrounded by a delicate membrane or skin, also formed of cells, sometimes called "epiblema," constitute and form the roots of plants. The main root of most plants striking from above downwards, gives

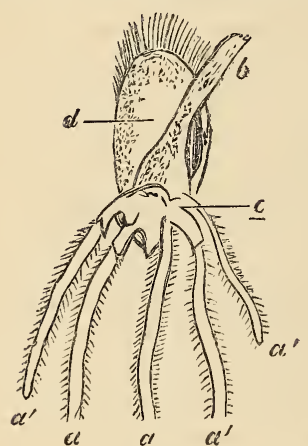

Fig. 3

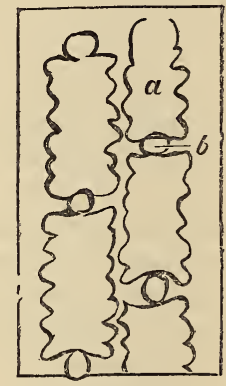

Fig. 4.

Fig. 3.-Grain of wheat germinating- $\alpha$, central root of axis- $\alpha^{\prime}$, other rootlets covered with hairs-b, plumule-c, cellular sheath or "coleorhiza" covering the axis or base of rootlets $-d$, the seed (after Balfour).

Fig. 4.- Microscopic view of cast of silica in wheat-stem after boiling in nitric acid (after Goadby) $-a$, siliceous plate with serrated edges, which flt in accurately to other plates$-b$, cast of stomata, or breathing-mouth of stem, in flint.

off numerous branches, the ends of which are formed of cells loosely put together, and thus, having a spongy texture, are called "spongioles," which are, however, covered like the rest of the root or rootlets, with the fine delicate membrane above mentioned.

It is through this membrane and the spongy texture of the spongioles that all the food of the plant obtained from the soil must pass. It is evident, therefore, that the food must be in a state of solution.

In the wheat-plant there is no central root. All the rootlets or 
fibrils spring from the axis, where they are covered with a cellular sheath. The centre fibril ( $a$, Fig. 3 ) being generally considered as replacing the principal root, it only remains to add that the root or rootlets is lengthened or extended laterally by cellular additions to its extremity. In plants whose branches spread, the roots are wisely ordained to spread also, and thus retain a powerful attachment in the soil. In the wheat-plant the roots do not extend or branch out far laterally, because the stem, being branchless, does not require such a provision.

Having thus formed a clear idea of a root-its branches, coverings, cellular texture, and sponge-like extremities, let us now notice how it performs its functions. In other words, how does the wheatplant feed?

It is, of course, obvious that the feeding of plants, whether by their roots, or other means to be treated of hereafter, must have reference to their growth and perfection, and it is with this connection in view that I shall treat the subject here. Let us at present observe the functions of the root. They are connected with one of the most interesting of natural laws.

If a glass cylinder be filled with a solution of sugar or chemical salts, and the end covered over with a piece of bladder, and if this cylinder be then inverted and placed in a jar of pure water, the following change will take place: two currents will be established through the bladder, one conveying a part of the solution of sugar out of the cylinder, the other a part of the water out of the jar into the cylinder, and these currents aro termed in reference to their directions in or out, "endosmosis" and "exosmosis." Now the root of the plant is a cylinder, containing in its vascular vessels a fluid having a density different from the water containing the plant's food in the soil. The vascular vessels, in fact, contain the excretions of the plant in solution-and thus a beautiful interchange of that which is useless with that which is all important as food. is set up. The excretions pass out by exosmosis through the membrano covering the spongioles, while the food passes in through the same nembrine by entosmosis. It is impossible to conceive anything more interesting or suggestive than the application of this wellknown physical law to the means by which plants feed.

Wo shall see, by and by, as wo proceed upwards in the scale of nature, that all the great physical laws known to man and applied by him in works of art, have been antieipated in the organisation of living things.

It is thus, then, that the roots convey the alimentary matter found in the soil into the plant.

Let us now examine hou the stem yroues. 
If we refer back to Fig. 2 (p. 3), we shall observe the plumule is marked out in the embryo plant at $g$.

As the root grows by the multiplication of cells, so does the stem increase and rise up above the surface of the soil. As the root derived its primitive nutriment from the sugar of the seed, so does the stem. The stem is destined, however, for different purposes. It has to bear the leaves and branches and fruit of the plant. Therefore, it has to be fashioned with distinct, direct, and unmistakable reference to these objects. The first leaf of the wheat-plant is the cotyledon (d, Fig. 2, p. 3). So soon as the stem appears above the ground, and forms its first true leaf, the use of the cotyledon is finished, and it dies. Every now and then, however, as the wheatplant rises up above the ground, there is formed a kind of platform from which springs a leaf. This is called a "node," and the spaces between each node are called "internodes."

What are the exigencies of the wheat-plant? It has to carry a heavy ear containing the grain, and provision must be made so that it shall bear this weight, and bend with it before the stormy wind without breaking. If the stem were solid it is obvious that it would snap across and break, and the grain would be lost. Therefore we find the form of cylinder is adopted, and the geometrical scholar knows full well that this is the form which a given weight of material will work up into the strongest support. But annual plants have, more or less, succulent, soft stems, and unless that of the wheat-plant were strengthened in a peculiar manner, the stem would not bear its weight. This is done in two ways; first, by the interposition of the nodes; and, secondly, by incasing the stem with a coat of flint. I need say nothing about the obvious mode in which the nodes strengthen the stem. The flinty coat requires a word or two of notice. If a piece of wheat-straw be boiled in nitric acid the vegetable matter will be dissolved, and a perfect cast of the straw in pure transparent flint may be obtained, as shown in Fig. 4, page 8.

But how is this? Have I not, in describing the roots, shown that all matters taken up by them must be in solution, and yet I now say that the straw contains a cast of flint, which is insoluble in that which will dissolve almost everything-nitric acid? How is this to be explained? Just in this wise. The soil contains flint in a state of minute subdivision, but still insoluble. When the elementary principle, silicon, is acted upon by the oxygen of the atmospheric air, which is allowed by our system of cultivation to get into the soil, it becomes oxidised, and "silica," or "silicic acid," the terms being synonymous, is formed. The silica exists nearly in a state of purity in rock crystal, common quartz, flint, chalcedony, \&c., and 
in any form is very insoluble in water or acids, but is readily soluble in strong alkaline solutions. When, therefore, the powdered quartz or flint comes into contact with the alkali potash, or soda in the soil, it produces a soluble chemical compound known as the silicate of potash or soda, and in this form it is taken up by the roots of the wheat-plant, and earried through the vascular vessels to the cells of the stem, where it is deposited as seen in the figure round the straw, not as the soluble "silicate," but as the insoluble "silica," or flint.

And here we have a fine illustration of the operation of vital force. The eell, by the multiplieation of which, as we have seen, the wheat-stem is built up, I deseribed as the individual protophyton, having the powers of a distinet being; we find it here acting as a conscious being would do, for it actually selects the silicate from the other minerals in the juiees of the plant, and then, by deeomposing it, renders it insoluble, and further so disposing it round the stem of the plant as to proteet it against the dangers with which its future is threatened.

Let us put this illustration of vital foree in another and still more forcible light.

Place a rhododendron, a sunflower, and a wheat-plant in the same flower-pot filled with soil. The soluble matters in that soil will pass by endosmosis through the membrane covering the spongioles of the root into the eellular tissues of the plant. The eell of the wheat-plant will seleet the silieate of potash, because a flinty coat is required for its stem. The cell of the rhododendron will seleet the lime and rejeet the silicate, because its stem is woody and solid. and does not require flint to strengthen it, while carbonate of lime is an essential part of its texture, its branches being designed merely to carry leaves, flowers, and light seed. In the third place, the sumflower will reject the siliea, and take up the potash and lime.

There are men in the present day who attempt to deny the existence of a vital as distinet from a physsical force. The same elass of men will argue that blind instinct is only a modification of reason.

$\Lambda$ s I shall hereafter have opportunities of diseussing the great subjects of instinct and reason, I shall eontent myself here by noting that they are clearly distinct from each other. The mason wasp provides fool for young that it never sees. There is here no comparison from experienes, and therefore the insect does not act from reason of its own. The act of the insect is instinctive. but the power which instituted the great law involved in this aet must have hat reason and forethonght. or the power of secing into futurity. The beaver builds his hint in the same namer as the first beaver did. It does not improve, therefore it acts from instinct, which is 
unchangeable. But man builds a very different house when civilised to that which he raises in his primeval forest.

Now just as instinct differs from reason, so does physical differ from vital force. The crystal attracts its elements from their solution in water, and takes upon itself its destined form now as it ever did in obedience to natural law, which is purely physical. But the cell of the wheat-plant selects the flint to strengthen the sides of the hollow cylinder of straw with reference to the existence of a world. If that power of selection did not exist in the cells of the wheat-plant and other grasses, all our cattle, and every human being on the face of the earth, would perish. The law of attraction fails to explain the act upon which such a vast issue depends. The unconscious plant-cell must be a passive agent. It yet performs an act far higher than anything human reason can effect.

Again, how irresistibly, and yet how unconsciously, are we led step by step from the physical to the vital-from instinct to reason, and from reason to the Infinite!

\section{CHAPTER III.}

\section{The Natural History of a Grain of Wheat (continued).}

The next stage we note in the history of our young plant is, that the stem forms leaves. Bearing in mind the modes in which cells multiply so as to constitute growth, we can understand how the leaf buds out of the node, and gradually grows to the length and shape so well known in the wheat-plant.

This leaf is oblong and lancet-shaped. It is covered at its basal attachment to the stem by a split sheath, and, if minutely examined, will be found to possess a short stalk or petiole; and at the point of junction of the petiole and blade, there is a membranous expansion, called a ligule. I need not illustrate all this, as plants for examination are always accessible even in winter.

Then, observe the leaf has two surfaces of different colours, one looking upwards, of a dark green, owing to the presence in its surface cells of an excess of a fluid containing a pigment known as "chlorophylle," which is the universal cause of the green colour of vegetable life. The other surface, looking downwards, is of a paler colour, owing to the fact that many of the cells contain air instead of "chlorophylle."

Now these air chambers have a certain analogy to the air cells of our own lung, for with the openings by which they communicate 
with the interior of the leaf, they constitute the breathing apparatus of plants. These openings or mouths are termed "stomata," and it is through their media that some of the most important operations in the economy of the plant are performed. These stomata are very numerous in the leaves of some plants, such as the lilac, in which 160,000 to the square inch have been calculated under microscopic examination. And it may be noted here that in water plants, the leaves of which swim on the water, as the lily, these stomata are in the upper part of the leaf. (See Fig. 6.)

Now let us go to our friend, Mr. Goadby, and ask him to illustrate for us the structure of a leaf as seen through the microscope. He readily furmishes us with the following microscopic view of a transverse slice cut very thin from the leaf of the common garden balsam.

I have selected the balsam to illustrate the structure of leaves, because it is thick and shows the parts clearly; but all leaves are

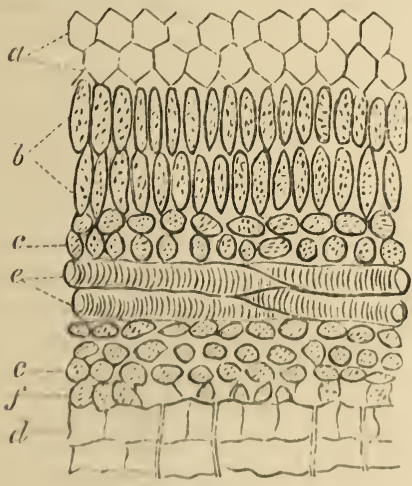

Fig. 5.

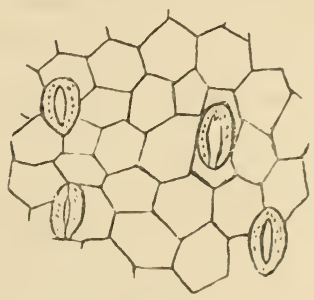

Fig. 6.

a, cells of the upper cuticle or skin$b$, cells contuining chlorophylle-cc, digestive or nutritive cells in central and under part of leaf $d$, cells of the lower cuticle or skin, contuining the stomuta, or nir openings - $e$, two spirul vessels.

Fig. 5 (altered from fiundby).-Vertical section of leaf of the common garden balsam (bighly magulllod).

Fig. 6 (after Balfour).-Stomata as seen on the upper surfuce of water plant (Ranunculus ailuaticus, blghly maguitled).

constructed more or less on the same model. They are, in fact, formed of a vast number of photophyta, divided into sets, each set performing a distinct and separate function. Thus we have the top layer, forming the epidermis or skin; just below the pigment cells: then the digestive or nutritive cells; and, Jastly, the lower skin and the mouths of the stomatil. There are also a series of vessels which are made up of cells and formed into tubes. These tubes are commonly known as veins, and are well seen in the skeleton leaves we pick up in our garden in winter. In the wheat and allied plants they rum parallel to each other. They are called "vascular vessels," 
and their use, like our own blood vessels, is to convey the fluids taken up by the roots to all parts of the leaf where important changes are effected, and to return it so altered as to subserve the purpose of nutrition to the plant. These vessels have all more or less a spiral character, like those shown in Fig. 5, e, p. 13. Some of them carry air, others fluid. In our wheat-plant these vascular vessels stop short in their development at a certain stage. In other plants, as most of our trees, new matter is continually being added to them externally, so that they ultimately form hard tissue, known as wood. There is also another system of vessels in leaves called "laticiferous," which, in fact, constituted the "proper vessels" of old writers. They are principally connected with the bark of trees. They convey a fluid called "latex," red, white, yellow, or colourless. They divide into very minute branches, only discovered by the highest power of the microscope. It is from these vessels that the milky latex exudes when we tear across the leaf of a lettuce. Leaves of course present an infinite variety, and their study is one of absorbing interest to the botanist.

I have said enough, however, to give a general view of the subject, and to allow us to take an intelligible glance at the functions of leaves.

We have seen that the roots, by means of their spongioles, take up fluid from the soil containing certain mineral matters in solution. This fluid is chemically altered, and has added to it organic matter taken in by the leaf from the atmosphere, and it then becomes the fluid known as sap. In other words, it is the nutritious fluid of the plant, bearing to it the same relation as our own blood does to our bodies.

I have shown also that the protophyton absorbs carbonic acid from the atmosphere, and it is by this means that the great amount of charcoal contained in the vegetable growth of the earth is produced. It is altogether a mistake, therefore, to assume that plants are injurious to health if grown in our living apartments. Carbonic acid in excess in our atmosphere is injurious to animal life. Plants remove it. It is to this power of absorbing and appropriating to its use the carbon of the atmosphere that we are indebted for our coal, gas, and fire. It is this which gives the essential element to the meat produced by our flocks of oxen and sheep. It is, in fact, a source of infinite blessing and comfort and happiness to the whole human race. Leaves are the great manufacturers of food in every part of the world. If we search the highest mountain, penetrate into primeval forests, or go down into the depths of the sea, we shall find leaves, or modifications of leaves, ever at work night and day in preparing the means by which animal life is supported. The 
herbivorous animal takes the food thus manufactured, and then others higher in the scale kill and feed upon the meat which it produces, and thus the great chain of animal existence is preserved.

It would be an insult to the imagination and intellect of my readers were I to dwell upon the beautiful and sublime thoughts which the mere mention of this great chain of facts must create in their minds. But in these pages I do not intend to get too much into what Mr. Newman happily calls "the groove." I wish rather to read with them the book of nature as seen in its inner aspect, and to create, if I can, that real love of the grand facts it presents to us which is felt by all who prefer indulgence in the pleasures of intellect to those of sense.

The first great function performed by leaves is to get rid of the excess of water drawn in by the roots. This is done by exhalation through the stomata, under the influence of light and warmth. This exhalation is much larger than ordinary observers have any idea of. A cabbage, for instance, is known in a warm day to exhale as much fluid as its own weight. Some idea may be formed of the quantity of fluid given off by the grass on a common lawn by placing an inverted tumbler upon it in sunshine, and observing the rapidity with which drops of water form on the glass inside. This experiment is best performed, as it was done by Bishop Watson, after several weeks' dry weather. He calculated that a meadow, so circumstanced and cut, during hot sunshine exhaled 6400 quarts of water in twenty four-hours. Dr. Carpenter has, however, noticed that the bishop did not allow for the fact that all exhalation is stopped during the night. But if we divide this by two, still 3200 quarts per acre during twelve hours is an enormous quantity, and will give us some idea of the rapidity and importance of this function of leaves.

The excess of fluid being thus removed by exhalation, the inorganic or mineral matters brought into the leaf by the roots are in a fit condition to unite chemically with the organic matter taken in by the stomata from the atmosphere. This function is termed, as in our bodies, that of respiration, and just as our blood by breathing is converted from venous into arterial, so is the crude sap changed by the breathing of the plant into the nutritions fluid known as true sap. During the process of human respiration, oxygen gas is appropriated and earbonic acid is given off ; during that of the plant, the opposite, as we have seen before, is the case-carbonic acid is taken in and oxygen given off; and thus it is that plants purify our atmosphero.

In aidition to the respiratory functions, there is another going on in leaves which has some analogy to that of our digestion.

All the 
green parts of a plant contain a pigment called chlorophylle; this pigment especially attracts carbonic acid from the air during light -decomposes it, stores up the carbon, and allows the oxygen to go free. This process is termed the "fixation of carbon," and is performed by the green parts of the plant alone.

We are now prepared to go on in our history and to study the next and final stage: The plant flowers and forms seed.

There is nothing in the wide and glorious field of nature more beautiful than the details to which I now draw your attention.

The process of flowering and forming seeds is essentially the same in all flowering plants, although the details vary considerably. I have said that a leaf is a lateral extension of the stem-so a flower is merely a modification of leaves without the power of extending its central portion or axis. When a leaf bud opens, it grows by

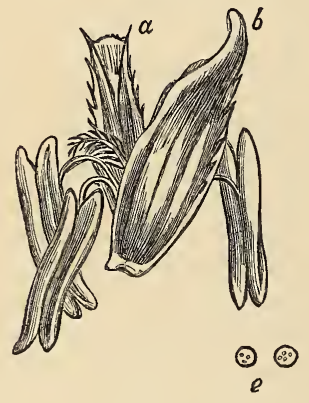

Fig. 7.

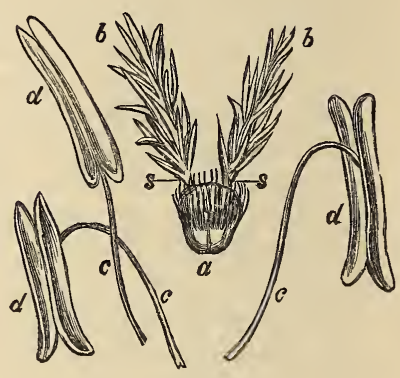

Fig. 8.

Figs. 7 and 8.-Wheat-plant flowering (after Henslow).

extending itself along a real or imaginary line termed its axis. A flower bud, on the contrary, consists of certain organs growing and increasing round a central fixed point or axis-and if it varies from this rule the flower is monstrous.

Everybody knows that an ear of wheat consists of a spikelet containing many separate flowers, each of which leaves behind it a grain of wheat. Viewed singly these flowers are well represented in Fig. 7. Those parts of the flower which are usually coloured are in the wheat-plant green. They are two, and are known in the ripe corn as the chaff. Botanically they are called "palea"-one inner $(a)$ and one outer $(b)$. If we tear these paleæ away we shall expose the other parts of the flower, as shown in Fig. 8 ; $a b$ constitutes what is termed the pistil, and is formed of $(a)$ the ovary and $(s s)$ the two styles, which at the end have a surface which secretes a sticky fluid, and is termed the stigma $(b b)$. It will be observed that the styles 
are in our plant feathered. These constitute the female parts of the flower. The male portion, as it is termed, consists of the three stamens $(c d)$. The filament $(c)$ is terminated by an oblong bifidlooking organ $(d)$; this is the anther, in which the pollen grains $(e)$ are formed.

Now the problem to be effected, in order that the grain of wheat should be formed and the race perpetuated, is that the pollen grain (e) should find its way into the ovary $(a)$. The anther $(d)$ opens and casts its pollen upon the stigma (b), which holds it fast there. Observe here that, although the ovary only produces one germ, there are two styles, which is an important provision to secure the certainty of the production of seed. Well, the pollen grain being caught by the stigma, can get no further, for, though loose in texture, the style is impervious. How, then, does the pollen grain get down to the ovary? Just in this way. The pollen grain, when sticking to the stigma of the style, splits its outer coat (for it is a protophytic cell, containing granules, and having two coats). The imner coat then becomes prolonged in the form of a tube, which pierces the loose cellular texture of the style (Fig. 9), and makes its way down until it reaches the ovary, where it finds a door, termed a micropyle, ready open to receive it. In the mean-

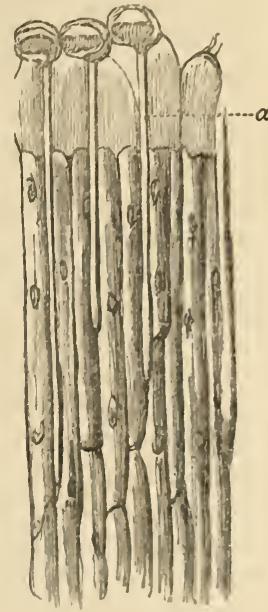

Fig. \%. while the granules which were contained in the pollen grain pass down through this tube, enter the ovary, and there form themselves into cells, which, uniting together, form the ovule or germ of the finture seed, with its four protophytic cells, its albumen, and its coverings, as I deseribed when I started on my journey. This process completed, the young cells are fed with the sugar, formel as in germination by the conversion of starch-and which every bee knows how to find; they thrive, the seed forms and ripens, and again we reach the point from which wo started.

In taking a retrospect of the natural history of our wheat-grain, we eannot exclude from it an expression of the highest almiration at the beatiful alaptation of "vital foree," which produces each part of the plant, and prepares it for its designed function. Let us look. for the moment, at oue phase in the series alone. We have serm that the leaf is only a modified portion of the stem, and that the llower, with its pistil and stamens, and coloured leaves or corolla. is only a moditiontion of leaves. In this intermeting featum of what 
is termed the morphology of the plant, we find an instance of a law which pervades the whole of organised nature-viz., the adaptation of similar means in the production of widely different results. And it is a law which, as far as our reason can tell us, is one of necessity. Were man, for instance, with his knowledge and experience, and assuming him to have the artistic skill, called upon to make a plant, he would form the roots and the stem; he would then modify the material of the stem into flat expansive processes, through which the vital fluids of the body could circulate, and become aerated by the atmosphere. He would then alter these processes into the complex and beautiful arrangement by which the species would be propagated. It would not be consistent with the unity and perfection of the plan were he now to introduce new textures. He would make use of the leaves, and would modify one into a bract, another into a calyx, another into a pistil, another into a stamen, and thus constitute a flower. And the necessity of this is apparent, for the flower has to be nourished through the medium of leaves, and therefore on just the same plan throughout.

And so we find that Infinite Wisdom has adopted that which our reason calls perfection in the creation and organisation of the world. But $\mathrm{He}$ has done much more, for $\mathrm{He}$ has endowed created things with a law by which they are not only perpetuated in time, but are also adapted to the purposes of existence. Thus we see that, under the operation of that law, the roots, the stem, the leaves, and the flower of the plant act in perfect harmony with each other, and seldom vary from their primitive form. If, however, man steps in and alters the circumstances of existence, the law which is immaterial and cannot change, refuses to co-operate with a non-natural condition of the being. Take a plant, for instance, out of its wild and natural locality, and cultivate and feed it highly : it is charged with a greater amount of nutrition than it was designed to assimilate, and we now see that remarkable change of the conversion of the stamens of the single plant into the leaves of the corolla of the double. But naturam expelles furchi, tamen usque recurret. Take away the excess of nutriment, and the plant will return to its original form, the leaves will become stamens, and the flower single again. 


\section{PART II. \\ THE PROTOZOON.}

\section{CHAPTER I.}

The Protozon: The Gregarina and Infusoria.

As the simple vegetable cell, the Protophyton, is the type upon which all plants are constructed, so does the Protozoon represent the primitive simple cell, by the aggregation of which all animal structures, whether flesh, bone, skin, hair, nail, feather, or scales, are formed. The animal kingdom is divided into five great sub-kingdoms, viz.:

1. The Protozoa, comprising the lowest form of animal life-of the Protozoon, in fact, in its simple unicellular character.

2. The liadiata, so called because they have a radiate form, like the sea-anemone and the beautiful zoophytes formerly thought to be flowers. The name, however, is faulty, inasmuch as animals like the star-fish and echinoderm, which have a much higher organisation and belong to a higher sub-kingdom, have marked radiate forms. The difficulty has been fully recognised by naturalists. The term Coelenterata, for reasons we shall see by and by, has on anatomical grounds been applied to the group.

3. The Molluscu, so called because their bodies are soft, like the oyster. This group includes the great mass of animals that are protected by shells, or tunics of softer naterial. A great number, however, like the garlen slug, are naked.

4. The Annulosu, so called because the bodies are formed upon the plan of segments, or annular divisions. It includes the echinoderms, wor'ms, crabs, lobsters, spiders, myriapods, and insects.

5. The Vertebruta, so called because each animal has a vertebral column, formod of a series of bones termed vertebra. It includes fishes, reptiles, birds, and mammals.

With this necessary preface, we will now deal with the first and lowest sub-kingdom.

\section{THE PROTO\%OA.}

This group is represented by five classes of animals, all consisting of simple cells, and therefore ranking in organisation nearly parallel to each other. Naturalists, however, have placed them in tho 
following order, beginning with what they consider the lowest form : 1. The Gregarina, 2. The Infusoria. 3. The Rhizopoda. 4. The Radiolaria. 5. Sponges.

I shall have something to say about each of these classes when their apparently unintelligible designations will become manifest; and first let us notice

\section{The Gregarina (from grego, to congregate).}

It will be better for me to say a few words here upon the distinction between animals and plants. And really this is a very difficult question, and one by no means decided by naturalists ; for although the most marked difference between the two organisms is found in the evolution of oxygen and absorption of carbonic acid by the plant, and the reverse by the animal, yet there are exceptions even to this rule. Moreover, the rule itself does not half help us in forming a differential diagnosis under the microscope.

Some naturalists have founded the distinction upon the possession of a mouth and stomach by animals, on the larger amount of nitrogenous principle in their tissues, and also on their possession of sensation and voluntary motion. But, as I shall soon show, there are undoubted animals which have neither mouth, stomach, nor locomotive or sensitive organs. Again, the ascidian mollusk contains a large amount of cellulose, a principle closely allied to starch. Starch is also found largely in the solid textures of man and animals, while, as we have seen, nitrogen exists in great abundance in the gluten of cereals and other plants.

The possession of sensation and voluntary motion is certainly almost universal in animals, but it is by no means deficient in plants, of which any one may satisfy himself by watching the movements of Volvox globator and other low vegetable forms under the microscope. In some of the Algæ, also, there are distinct movements observed in the granules which exist in the juices of the plant. In the Confervæ these granules are observed to move towards a particular spot, where an aperture is formed, from which they escape and move about in the surrounding water. Under a

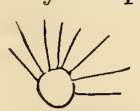
high microscopic power these granules are seen to have cilia or hair-like organs attached to them, by which they move about in the water. They have the figure as in margin.

After a time the cilia disappear, and the granule fixes itself to the side of the vessel, and becomes elongated, thus:

It now forms a cell wall, and increases in growth by the

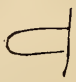
formation of other cells like itself.

The great class of Diatomaceæ-a series of organisms whose 
flinty remains form some of the most exquisitely beautiful objects under the microscope, and of which I believe nearly two thousand species have already been described by Dr. Greville and others-are not allowed to be claimed by the botanists unchallenged. I remember the late Dr. Trail, of Edinburgh-a man of very great informationcame to the conclusion that they were of an animal nature, because in Norway there is known an earth called the "bread earth," which in times of scarcity is eaten by the poor as a substitute for bread, and which., when examined by the microscope, is found to contain vast numbers of Diatoms.

Now it will be admitted there will be less force in Dr. Trail's inference, when it is considered that plants alone have the power of forming the material of animal structure-viz., proteine. This the animal cannot form itself, and it becomes one of the cardinal distinctions between the two great kingdoms of nature.

If, however, I am asked to give any distinct rules by which the microscopical student may at once distinguish the protoplyyton from the protozoon, I cannot do so. Our knowledge upon this point is entirely based on the dicta of the authorities in science, to which, however, as a rule, we may very safely defer.

Taking, therefore, the highest authorities as my guide, I shall now draw your attention to an examination of the lowest known form of animal life.

In the intestines of insects, worms, and mollusks, the microscope will detect small cellular bodies moving about by means of undulations of their cell walls. These are living animals, parasitical in, and living upon, the absorbed nutriment taken in by the insect or worm for its own special use. They have neither heal, eyes, mouth, orgaus of locomotion, digestion, circulation, nor sense. They are simplo cells, containing a nucleus and an albuminous fluid with granules called sarcode. They move about by means of wave-like umlulations of their cellular bodies. Fig. 10 (p. 22), taken from the "Icones Histiologicio" of the celebrated Professor of Anatomy at Wurzburg ( $\Lambda$. Koilliker), shows one of these minute organisms largely magnified.

I have given only one of the forms of this singular animal, but it is often romol, snmetines oval. It is colomrless and microscopic. As to si\%, if we tako a fine nendle and make the smallest mark visible to the naked eye, we should fail in giving any idea of its minuteness. It is quito invisible to the naked eye. I do not find any mensurements given by anthors. These figures, therefore, which illustrate this chapter, are all enlanged from the nicroseopie high-power inatge for tlu purpose of illustration.

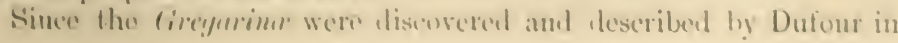


the "Annal. de Sci. Nat." vii., 1837, down to Kölliker's "Icones Hist.," 1864, they have been well examined by naturalists, and some very curious features in their economy discovered. At first about eighty species were named and divided into genera. It was, however, found that many of the forms thought to be specifically distinct were only the different phases of the metamorphoses which the animal undergoes in its reproduction. These changes I will describe.

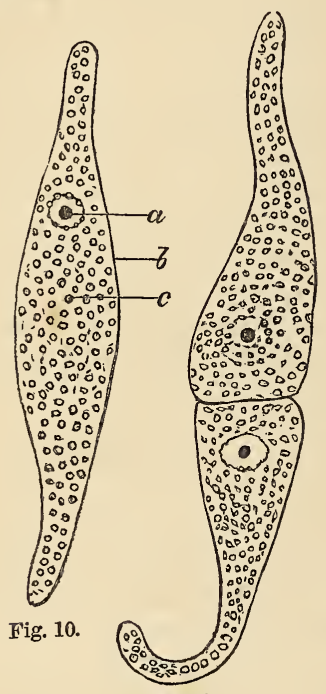

Fig. 11.

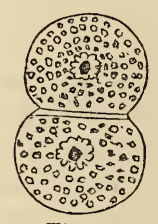

Fig. 12.

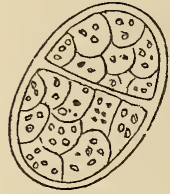

Fig. 14.

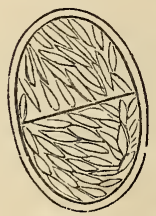

Fig. 16.

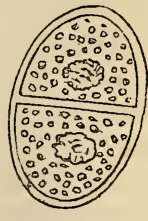

Fig. 13.

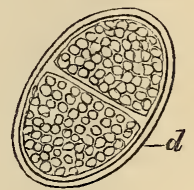

Fig. 15.

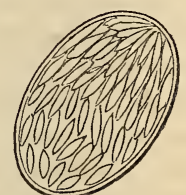

Fig. 17.

Fig. 10.-Gregarina nemertis (Köll.), highly magnified-a, nucleus, containing nucleolus $b$, cell wall-c, granular contents of cell.

Fig. 11.-Two Gregarinæ united together.

Fig. 12. - The same, contracted.

Fig. 13. - The same, forming cell wall, and nucleolus disappearing.

Fig. 14.-Nucleus divided and enlarged.

Fig. 15.-Further division of nucleus, and formation of "cyst membrane" $(d)$.

Fig. 16. - Same cell, containing "navicular"-shaped bodies, and band of division disappearing.

Fig. 17.-Same. cell, containing matured larvæ of Gregarinæ, band of division and cyst membrane entirely gone (after Kölliker).

First, two of the elongated cellular nucleated creatures shown at Fig. 10, having become obtuse at the extremity nearest the nucleus (a), come into contact with each other, as shown in Fig. 11. The extremities then contract, and the next transformation is shown in Fig. 12, where it will be seen they have become firmly united into 
one body, still having two nuclei, and a band of division. In the next change, which is observed in Fig. 13, it will be remarked that the dark spot shown in the centre of the nucleus (Fig. 12) has disappeared, and that the contents in each division are now surrounded by a delicate inner membranous envelope, separating them from the outer cell wall, and also the two divisions from each other. In the next (Fig. 14) the granular matter will be found to have formed itself into a series of distinct round-looking bodies, which in Fig. 15 are seen to have subdivided into a much greater number, while an outer membrane $(d)$ now covers the cell. In Fig. 16 it will be noticed that the inner envelope has become thickened and continuous all the way round, while the globular masses in Fig. 15 have become changed into navicular or boat-shaped bodies. In Fig. 17 the band of division is finally withdrawn, and we now have a cell full of the boat-shaped forms seen first in Fig. 16. These are the larva, which, when mature, are set free by the bursting of the cell (Fig. 17), and become developed into the perfect Gregarina.

Now let us notice the salient points in this beautiful series of processes. We have, first, the union and mingling together of two perfect gregarinids, then the formation of a cell wall, then that inarvellous division and multiplication of the nuclei, then the change from the globular to the boat-shaped germs or larvo, the obliteration of the division which separated the upper from the lower part of the cell, the liberation of the larve and their development into beings, lowly as they are, yet destined to occupy a place in the scale of organised nature. And yet this creature can only be seen by the aid of the inicroscope, and its home is in the intestines of worms and insects!

It is most interesting, and well worth our while, to observe attentively the changes which take place in these low forms of animal life cluring their perior of development. Not only do they shadow forth much that is observed in higher forms of animal life, but the changes themselves are very curious, and utterly incomprehensible to our limited faculties. Every movement and change takes place with the most perfect orter and regularity, and seems, as Kiblliker himself has remarked, to be under the direct operation of the will of the creature. And yet how can we assign a will to a speck of jelly containing a fluid and a few granules?

The division of the mucleus, when viewed under the microseope, is a most beatiful sight, each particle into which it separates forming the nuclens of a new growth (Fig. 11). which takes up all the granular matter soen surrounding the nucleus in Fig. 13. These new growths again subdivide, and the product is the more highly organiserl bodies seen in Fig. 15. Observe, also, that in this stagro 
of the development a "cyst membrane" ( $d$, Fig. 15, p. 22) is thrown round the cell to strengthen it, and enable it the better to hold its contents until they are entirely developed, when it disappears, and the cell bursts.

This encysting in reproduction of these organisms is constant throughout a class which Grant has called Cystodia, and of the three orders into which he has divided this class the Gregarinea, as he calls them, is the first. It is also characteristic of animal life, and may be added to the distinctions between plants and animals. It is worthy of remark, as showing the border ground between animal and vegetable life occupied by these cells, that M. Bary, of Prague, has lately demonstrated that certain forms of fungi belonging to the Mycetozoa are most probably referable to the Gregarince. These fungi are, in Grant's words, "composed of aggregations of simple cells, commonly referred to the vegetable kingdom."

\section{The Infusoria.}

If a small quantity of hay, grass, or other vegetable or animal matter be covered with water and allowed to stand for a few days exposed to the atmosphere, and a drop be then placed under the microscope, it will be found teeming with life. Hence the animalculæ which may be produced by infusing organic matter are called Infusoria.

Their occurrence under the circumstances mentioned has given rise to the theory now held with great pertinacity by $M$. Pouchet and others of spontaneous or equivocal generation, which simply means that the animal Protozoon may be produced and endowed with life from the elements of dead organic matter. This doctrine, however, which has been supported with great ability and careful experiment by M. Pouchet, has been successfully combated by M. Pasteur, who has satisfactorily proved the truth of the doctrine hitherto held, that these organisms are produced from germs which are always either floating in the atmosphere, or mingled with the organic matter whose decay forms for them the "circumstances necessary for their existence," at the time of which decay, and only then, they produce the living creatures known as infusorial animalculæ. The discussion between these inquirers, and a detail of the experiments which each of them performed, have been published in almost all the natural history magazines in this country during the last four or five years, and it therefore is unnecessary for me to say more upon the subject here.

There are few objects more interesting, and to the student more startling, than the examination of a drop of water from a stagnant ditch, or a basin in which vegetable or animal matter, such as a 
dead oyster, has been allowed to decompose. Those who have not microscopes may see all the Infusoria in Pritchard's translation of Ehrenberg's great work; but half the charm is lost if they are not seen alive. Their motions are so quick and graceful, their form so varied, their habits so singular, that they who are unaccustomed to microscopical investigation are always, when shown this sight, filled with astonishment and delight. The scene is continually varying. At one time you see a number of creatures of an oval shape, more or less pointed or obtuse, dart across the field of the microscrope like the shuttle of a weaver, rebounding when they come in contact with each other or any of their companions, but generally making good way. These are divided into many genera, such as Paramæcium, Euplotes, Loxodes, \&c. Then will be seen rolling along the globular confervoid (Volvox globator), coloured green, as a plant ought to be, and containing many easily secn young volvoxes within it. Now a waving, sneaking, leechlike-looking thing (Loxophyllum) will show itself, followed by the trumpet-shaped Stentor. But stay; what was that which suddenly seemed to be in and then out of sight again in a moment? Keep as still as a mouse, and you will observe that you have got a bit of the root of duckweed in sight, and from this root you will see gradually coming out, as it were, a stalk, and then the end of the stalk will appear to expand into a cup-shaped extremity, the edge of which is surrounded by hundreds of small hair-like organs (eilia) which immediately begin to work about with a motion so rapid that you ean hardly see them. Eight, or ten, or twenty, or more of these cups, each with its separate stalk, may be observed : thus ereating a current in the water in order to draw into the same eup any other animaleules, which, whether, they will or no, once in the current, like the unlueky boat over Niagara, are carried away to their destruction, for the Vorticelle ncbuliferce is fecling. The slightest movement of the microscope, and quick as lightning, every cup, by a corkserew-like action of the stalk, is diawn down to the root of the duckweed. If you watch them long enough, you will find some of these eups are splitting in twoeach half forming a perfect eup-and as one stalk is too much for two, one of them separates and goes into the work of waters on its own account. There aro many different species and genera in the family of Vorticellina, all of which are interesting objects under the microseopo. But what is the object with revolving wheels? It is a "wheel animalcule," one of the Rotatoria, but it belongs to a much higher class than our Protizom, so we must defer all notice of him. though one of the most beantiful and interesting objects seen through the microseope. 


\section{CHAPTER II.}

\section{The Infusoria (continued).}

In the early period of our acquaintance with the infusorial animalculæ a very erroneous idea of their structure was entertained by naturalists. This was principally owing to the fact that Ehrenberg, to whose investigations our knowledge of the vast number of species was principally due, was not so good a comparative anatomist as he was an observer. Hence the lowly infusorial animalculæ were placed in a much higher position in the animal kingdom than they can lay claim to. Muscular power, nerves, a blood circulation, and a multiplicity of stomachs (hence their name Polygastrica) were assigned to them, without any foundation in fact. They are unicellular Protozoons. Before I make this obvious, let me say a word or two about one or two parts of their organisation which they have in common, and which will be frequently alluded to.

Sarcode is the term which has been assigned to the jelly-like substance of which the bodies of the Protozoa are formed. It has been called liquid flesh. It is, however, the substance which supplies the place of flesh in the lowest animals, and resembles it in chemical composition, but differs in the absence of muscular fibre. It is semi-transparent and variable in colour. It is insoluble in water; and, when dried, its physical characters are restored by immersion. Its singular properties will be noticed as we proceed in the description of the Protozoa. All the bodies of the Protozoa, including the Gregarinæ, are formed of this substance.

Cilia are the minute hair-like bodies which fringe the oral apertures, and in some instances all the surfaces, of the Protozoa. They occur in both vegetable and animal structures, from the Volvox globator up to man himself. They have very remarkable properties, either as organs of locomotion, or as, by their rapid motion, the cause of currents by which food is drawn into the mouths of creatures otherwise unable to obtain it. On a large and familiar scale, they are illustrated by the human eye-lashes. They are from .02 to $\cdot 00005$ of an inch in length in the Protozoa, and their movement is so rapid, that they are frequently invisible through the microscope, and their presence only inferred by the currents which they produce. They move uniformly with regard to each other, each bending from its base to its point at the same instant of time. This motion ceases or commences in obedience to what appears to be the will of the lump of jelly constituting the Protozoon.

Let us now take one of the best known forms of the Infusoria, Paramcecium Bursaria, and with the aid of the cuts we shall be able 
to get a very fair knowledge of the structure of the entire group. Fig. 18 is a view of the animalcule as seen when looking down through the microscope upon its back. Observe, first, the mantle of cilia which covers its entire surface. These are its organs of locomotion, and also, as just stated, the media by which it forms currents and draws its prey within its grasp. Minute and delicate as are these beautiful organs, my friend, Professor Allman, of the University of Edinburgh, discovered that the creature has imbedded in its "cortical layer" a vast number of cells, of a peculiar construction, called trichocysts, which the animal can burst at will, and from which protrude a great number of extremely fine (even

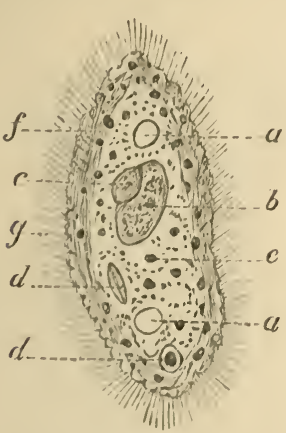

Fig. 18.

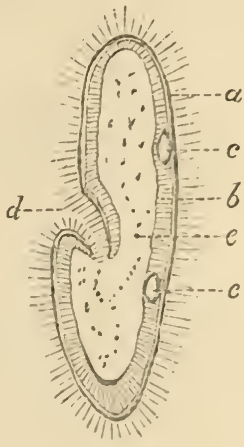

Fig. 19.

Flg. 18.-Paramecium Iursaria, dorsal side (aftor Stein), magnitled 301) diameters-a $a$, coutractlo chumbers-b, uncleus $-c$, nucleolus $-l l d$, particles of food surrounded by a rin of wator $-e$, chlorophylle grains $f$, cortical layer, on the outside of which is the " cutleula" or outer coverlng, bearhig $(g)$ tho clliu.

Flg. 19.-Diagrammatic soetion of l'urumacium Bursaria-a, the double line represents the cutlenla, or apereted outor onvolope, carrying the cilia-b, the cortical layer, passiug through which the urticating threals aro seon. Whon the animal does not uso them they aro Inelosed In colls termed trichocysts $-c c$, tho contructile chanbers in the cortical layerd, tho mouth-P, the "contral sarcole," whlch, hesing thimer than that of the "cortica! layer, "Is continually cireulathe round the space it oceuples, earrying with it the food. It contuins the nueleus, ke, as shown in precedlng llgures, which is, howover, generally attuched to tho cortleal layer.

when compared with the cilia) threads, which are supposed to have the power of benumbing its prey-a power well known to bo possessod by these threads in animals higher in the scale. Observe now the shape of the body, and note that all the way round there is a thickened border or edge, which consists first of an outward structuroless covering, which is. in fact, an crevetion from the holy of the mimalcule. This is termed the cutioulu, and the rest of the dark border consists of sarcode, and is called the "cortinal laver" (Fig. 19). This cortical layer gradually beromes softer mutil it is somifluid, and in this condition the sarcente fills up the rest of the body. 
Now let us examine the objects seen through the clear diaphanous substance of the animalcule. First, notice the two clear circular spaces marked $a$ a, Fig. 18 (p. 27). These are termed the contractile chambers or vesicles, which are observed to be continually opening and shutting - that is to say, they are alternately visible and invisible. Now these contractile chambers, or vesicles, or spaces, as they have been at different times called, are a marked feature in the structure of the Infusoria. They are observed to be connected with channels having a communication with the outside of the body, through which these chambers are alternately filled with and emptied of water. Kölliker has shown this in a beautiful series of figures in his "Icones Histiologicæ," which I have copied (Figs. 20-24).

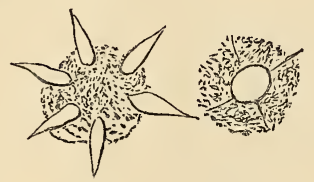

Fig. 20.

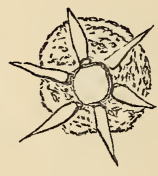

Fig. 22.

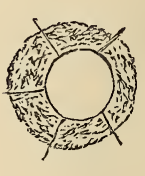

Fig. 23.

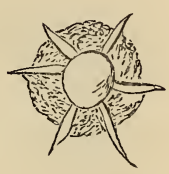

Fig. 24 .

Figs. 20-24-Contractile chamber of Paramæcium in five successive stages (after Kölliker), magnified 500 diameters -20 , the chamber or vesicle contracted, and the rays filled with water-21, the first emptying of the rays and simultaneous filling up of the chamber22 , the second filling of the rays-23, the second emptying of the same, and probable filling of the chamber-24, commencement of the emptying of the chamber and afterfilling of the rays.

This water circulation is, no doubt, connected with the process of respiration; that is to say, it is the means by which oxygen suspended in the water is conveyed to the interior of the animalcule, and carbonic acid conveyed away.

And mark, this beautiful apparatus is one of the types upon which this class of living beings is formed. We shall see by and by, in the higher animals, many different modes of breathing; but in none shall we find an exact repetition of these contractile chambers and canals. Now let us look at the two bodies marked $b$ and $c$, Fig. 18 (p. 27). These have been named the nucleus (b), and the nucleolus (c). But they do not represent parts equivalent to the nucleus and nucleolus of cells. The body marked $b$ is, in fact, the ovary, and $c$ bears the same relation to it as the pollen grain does to the ovary of the plant, as we shall see by and by.

At $d d$ notice particles which have been swallowed as food, surrounded by globules of clear water, which was probably taken in with the food. These globules were considered by Ehrenberg as so many distinct stomachs, and upon this mistake was founded the order Polygastrica, or "many stomachs." This, as I have already stated, is quite erroneous. At $e$, and scattered all through the 
interior of the animalculæ, and carried into the fluid sarcode, is a constant circulation from left to right; round the general cavity are numerous granules of chlorophylle, which give it a green colour, and which we have scen before is the pigment of vegetable structure, and is always floating about in water. Now let us turn the little creature over upon its back, and notice what comes into sight as shown in Fig. 25. At $a$ we have the mouth, and at $b$ the gulletbut mark, no stomach. The gullet simply carries the food into the bag, which is inclosed by the "cortical layer," and in which the liquid sarcode circulates, carrying with it the particles of food, chlorophylle, granules, \&c.

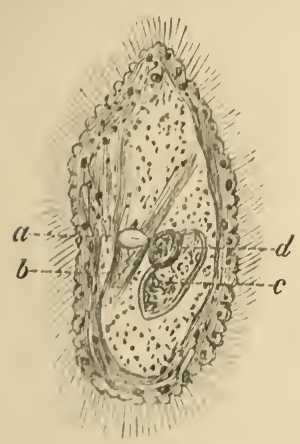

Fig. 25.

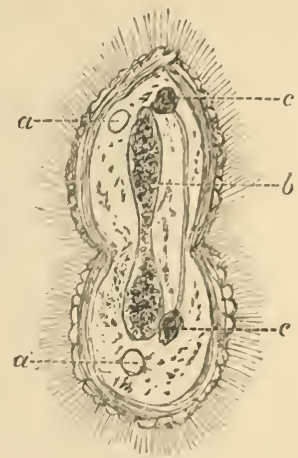

Fig. 26.

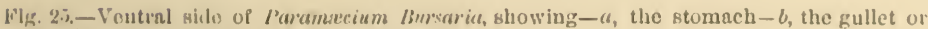
assoplungus-c, the nuelous- $l$, the nueloolus.

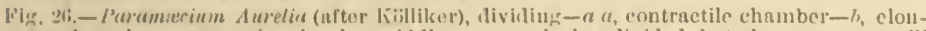
fated nuclens contracting in the midillo $c$, nucleolus divided, but the new ones still connoctorl with onch other.

In Fig. 26 we have an illustration of one of the methods by which Infusoria increase. The nucleolus divides into two, and each division attaches itsolf to the ends of the nucleus, the latter becoming at the same time clongated. The animalcule and nucleus are observed to become thinner in the middle, and ultimately they divide into two distinct animaleules, which again sublivide, and so increase and multiply. It has recently, however, been discovered by M. Balbiani, and contirmed by Stein and Kïlliker, that the Infusoria are also reproduced by the following means. The nucleolus (c, Fig. 1s, p. 2i) represents tho malo part of the creature, just as the pollen grain does of tho plant: while the so-called uucleus (b) is the ovary. At certain seasons the mucleolus is observod to grow in size: and in this comblition two animaleules become conjoined, as shown in the Cregarins, and, mingling together, the nucloolus of enoh division 
passes into the ovary of the other. Here, as in the plant, the germs of future Paramæcia are formed in the shape of round bodies. These become of an oblong shape, then covered with cilia, and in this form are set free from the parent cells, and start on their own account as young fry in the great struggle for existence to which the nomad as well as the man is doomed.

But there are two other modes of propagation among the Infusoria. To illustrate these singular phases in the life history of these lowly forms of animal existence, let us examine the economy of the Vorticellinæ, considered by some as typical forms of the Infusoria. Fig. 27 is from a drawing of a group of Vorticella nebulifera, attached by their stalks to a bit of the root of duckweed. They are seen in all the positions they assume under the microscope, except that in which

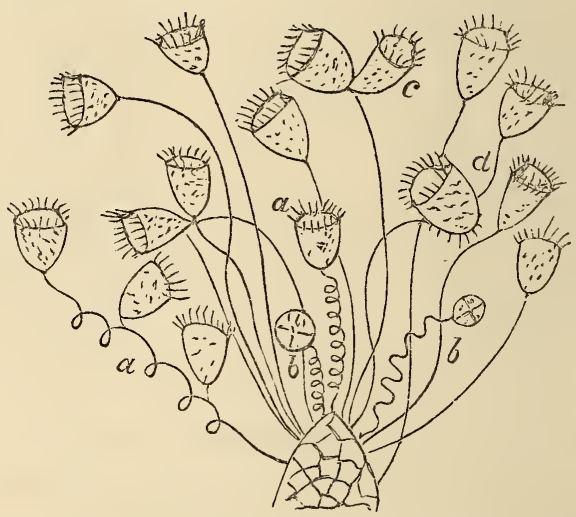

Fig. 27.-Vortucella nebulifera (highly magnified) - $a a$, unfolding $-b b$, retracting-c, dividing $-d$, bell separated from stalk, and having a posterior circlet of freshly-developed cilia.

they simultaneously contract and draw themselves down to the root to which they are attached. Their structure is not such as would be inferred by the appearance of the group. Let us, therefore, follow the history of an individual, say that one marked $d$, which is seen to be falling away without a stalk. The bell has just been developed by division, or fissiperation as it is termed-the process described in Paramæcium. The division is completed at $c$, and $d$ has just separated from the animalcule whose stalk it is represented as bending. Note, first, that this cup or bell has a series of cilia provided for it at the end opposite to the mouth. These are its principal locomotive apparatus, and by their means it swims about in the water. When, however, it finds a place suitable for its purposes, it becomes attached thereto by this end, and the locomotive 
cilia become gradually changed into a staIk, which by growth is developed into the singular elastic contractile organ shown in Fig. $28(h)$. The exact nature of this stalk has not yet been fully made out. My friend Professor Bennett, of Edinburgh, considers it contains contractile tissue, and that it is merely a prolongation of one of the layers of the bell itself.

Be this as it may, this stalk is certainly a tube, which contains a thin thread-like band, which $I$ have shown in the figure at $i$ in the form it appears in the interior of the stem.

Now then, the stalk having grown to its full length, the animalcule may be considered as mature, and we are able to see through its clear body all that is contained therein (Fig. 28).

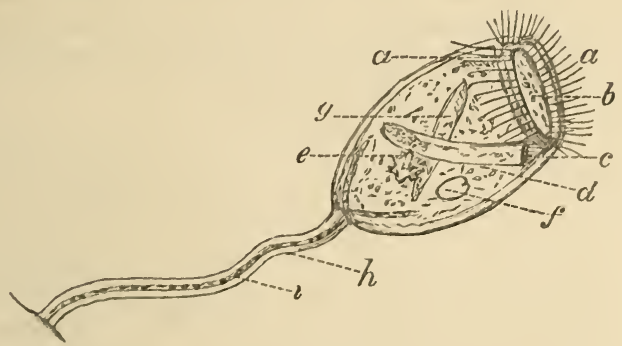

Fig. 28. - Diagram of Vorticella $-a a$, the peristome-b, the disc $-c$, the mouth $-d$, the gullet $-e$, opening in gullet $-f$, contractile chumber- $y$, nucleus $-h$, stalk-i, contractile flament, supposed to bo the continuation of one of the conts of the animalcule.

First, however, observe the rim round the distal extremity of the cup (i). This is called (from the two Greek words signifying "about" and "mouth") the peristome. Note also that this peristome does not carry the cilia. This is done by what is termed the "lise," which is placed within the peristome, and has its outer edge furnished with one or more circlets of cilia, which assume a spiral figure. The mouth $(c)$ is placed in a small space between the disc and the peristome, and the cilia are observed to commence a little to the right of the mouth and, going to the left, run once or twice round the edge of the dise, and then terminate inside the mouth in what is called the restibulum.

Thus what appears to bo the open mouth of the bell is closed in by the dise, and the animaleule has tho power of drawing this disc inwards, when the peristome will contract and cover it in. It is impossible to show the curious arrangenent in a drawing, but the abovo description will. I think, render it tolerably clear, with tho aid of tho diagrammatic Fig. 2s. Woll, then, the action of these cilia forms a current, which brings to the mouth other animaleules 
upon which it pleases Vorticella to feed. But strange, yet true, this mouth exercises a power of selection, and, by the assistance of small non-vibratile cilia which pass through the mouth into the gullet, it rejects all non-nutritious particles, and chooses soft eatable animalcules only. The food goes into the gullet, and, after remaining at the bottom thereof for some time, it passes into the general cavity through an opening at $e$. The nutritious parts are now dissolved in the juices of the body, and the rest sent out by the same opening through which it found admittance.

The contractile vesicle, nucleus, and nucleolus are shown, but the changes in them are similar to those described in Paramæcium. Now this animalcule may increase by fission; now and then, but not often, a bud grows out at the bottom of the cup, which is doveloped into a perfect bell, and being provided with posterior cilia, like $d$ (Fig. 27, p. 30), goes through the same processes of development which $I$ have just described.

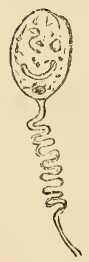

Fig. 29.

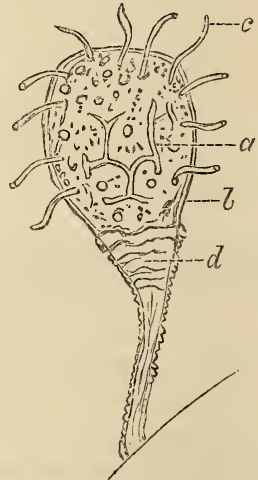

Fig. 30.

Fig. 29.- Vorticella encysted on its stalk.

Fig. 30.-Acineta stage of Opercularia articulata (one of the Vorticellinæ) $-a$, dendritic nucleus - $b$, cyst-c, tentacles- $d$, enlarged stalk.

Strange as are these undoubted facts, there is one mode of reproduction stranger still. Instead of conjugating, dividing, or budding, our Vorticella may adopt a still more complicated means of reproducing its kind. It draws in its disc, as noticed above, and the peristome contracting the bell becomes of an oval shape. It now envelopes itself in a cyst, as we saw the Gregarinæ do, which cyst is a mere secretion from the sarcode body. It has now the appearance shown in Fig. 29. It then pushes out tentacular appendages, the stalk thickens, and it looks for all the world like a gutta-percha elastic bottle, as shown in Fig. 30. No wonder that its best friends 
failed to discover our beautiful bell in such a shape, and it was therefore considered by grave classifying philosophers to belong to an altogether different family, and a new genus, termed Acineta, was formed, to hold the various forms of spiny bottle-shaped looking creatures. Some of them choose to attach their stalks, or, having no stalk, to develop one and become attached to each other, and then a new genus, the Podophrya, was formed. Luckily, our little Vorticella having developed a nnmber of young germs within her bristly bottles, the said bottles burst, and the young fry, being watehed by philosophic eyes, are found to be nothing more than veritable Vorticellø!

Now, in all the changes which I have described in the different parts of the infusorial animalcules-in the formation of their coats, their cilia, mouths, gullets, contractile spaces, nuclei, and nucleoliit must be distinctly understood that $I$ have not referred to a single structure which is organised in the strict sense of the word. No one has yet discovered anything like a membrane, or any of the structures by which the different organs in the higher classes of animals are built up. All that is yet known about them is that they are simply formed in overy part, outwardly and inwardly, of the jellylike substanco known as sarcode. That our knowledge upon this subject is still limited I certainly do believe. These lower forms of life have not received that attention from our English histologists which they have done from the German and French. Professors Huxley, Carpenter, Allman, and Greene, Dr. S. Wright, and Mr. Bowerbank are, however, names of celebrity, and from them the Protozoa have received much attention. I wish they would give us a work like the "Ieones Histiologicas" of Kïlliker. Perhaps Dr. Beale will some day tum his one-fiftieth objective upon this lowly race of beings, and tell us what 2500 dianeter's will show him.

\section{II $\triangle \mathrm{PTER}$ TII.}

\section{'Tue RHzorods.}

ТАкЕ a drop of water from any stagnant ditch, and place it under the microscope. Disregard the humdreils of creatures which we dealt with in the last chapder, and fix your attention upon that shapeless mass which lies on one side of the microseopie tielid. It looks like somo extraneous substance which has stolen unbihlen into tho arena of our stuling; hut knep your egn notwithstanding upon 
that apparently inanimate speck of jelly, and presently you will observe that it has motion. If your observation, however, happen to be interrupted for ever so short a time, you will be surprised that you see this thing no more. There is something there, indeed; but, instead of appearing like Fig. 31, it has assumed a shape perhaps like that shown in Fig. 32 ; and while you fix your excited attention upon this, it will alter before your eyes to the semblance of Fig. 33 ; and again, ere you can express your wonder (if this is your first sight), it will have changed to something like Fig. 34, and, with equal rapidity, to a form like Fig. 35. Now, if you look for an hour you will probably not see it assume the same figure again. It is always changing, and hence has received the name of the Protean animalcule. It is the Amoeba, and one of the typical forms of the Rhizopoda-thus named because the so-called feet or pseudopodia are pushed out from the body so as to appear something like the roots of plants.

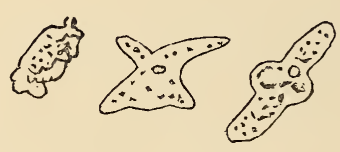

Fig. 31. Fig. $32 . \quad$ Fig. 33.

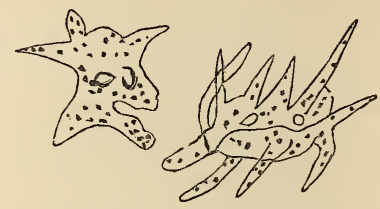

Fig. 34 .

Fig. 35.

Figs. 31-35.-Forms assumed by Amoba under the microscope.

Now, this Amoba, which I have selected to illustrate the Rhizopoda, has been designed to play a very important part in the physical history of the world, as I shall show by and by. Agassiz, the Owen of the United States, has, in his recently published "Graham Lectures," taken the ground that, although the earlier forms of animal life were created myriads of years before man, they were, notwithstanding, formed with an evident reference to his appearance on earth. I have held the opinion for some years, and I have strong evidence in this direction to give in favour of our little lump of sarcode-for it is nothing more. Dr. Carpenter, in his "Introduction to the Study of the Foraminifera," published in 1864, by the Ray Society, thus speaks of the Amoba: "It is a particle of apparently homogeneous jelly, changing itself into a greater variety of form than the fabled Proteus, laying hold of its food without members, swallowing it without a mouth, digesting it without a stomach, appropriating its nutritious material without absorbent vessels or a circulating system, moving from place to place 
without muscles, feeling-if it has any power of doing so-without nerves, and not only this, but in many instances forming shelly coverings of a symmetry and complexity not surpassed by those of any testaceous animals:" (pref., p. vii.)

Now, there are two divisions especially under which I shall endeavour to illustrate the peculiar history of this singular creature. First, those which are either naked or else invested with a covering softer than that afforded by shells. Secondly, those which form, and live in, the beautiful shells known as Foraminifera.

The first series are well represented by the Proteus-like Amcba found in fresh water, to which I have alluded above. It is, in fact, the type of the family, and, having observed it changing its form, let us now look at it while feeding. If you fix your attention upon the creature, you will notice that some other animalcule or an atom of vegetable matter will now and then come in contact with the body, and seem to be unable to get away again. In all probability this is owing to an urticating power possessed by the Amœba. Be this as it may, its fate, if a living thing, is sealed. By a peculiar action of

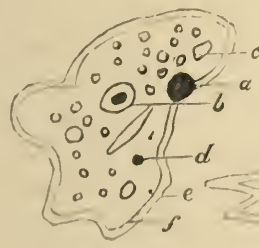

Fig. 36 .

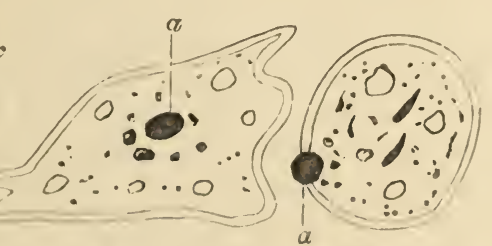

Iig. 37

Fig. 3s.

Fip. 36.-Food passing into the Amorlu. $-a$, the food-b, the nuclous-c, vacuoles or air spaces-il, gruuules-e, ectosarc- $f$, endosnre.

Flg. 37.-Food bronking up into smallor parts in the interior of $A$ maba.

Wly. 8s. - Undigestible parts of foud passing out through coats of A maba at $a$.

the protruded parts called pseudopodia, the object is pressed against and through the outer covering or ectosare, as it is termed. and then through the inner envelope or endosare into the interior of the cell. called an Amoba. The structure of the creature is simply two coverings inclosing a softer portion of sareode, having contents rery similar to those described in tho Infusoria. Having thus been forced through the sarcolous envelopes, the substance breaks up into gramules, which are sent round the fluid in the interior of the bag, during which process all thit is nutritious is extracted, and that which eamot bo assimilated collects on the opposite side, and makes its way through tho two coverings out again. These several events are illustrated in Figs. $36,87,83$. 
The above process is thus described by Dr. Carpenter: "This movement is effected by the protrusion of some part of the periphery of the body into a. pseudopodian process of greater or less elongation. Towards this process, and usually for some way into it, there is a current of the internal granular substance; at the same time there is a retraction of any processes of the like nature which might have been previously put forth from the other side of the body, and a reflux of the granular substance from these towards the centre; and by a continuance of this change the entire body is gradually advanced in the direction of the new extension." MM. Claparède and Lachmann think it possible there may be an oral aperture, of which the lips might be applied exactly to one another, and only open at the moment of deglutition; and they support this opinion by asserting positively that there is such an opening in an allied. forms to which they have given the name of Podostoma.

But this singular creature, while it is exactly similar to the figures given above of Amoba when in repose, has the power of propelling "whiplike filaments" from the end of each footlike process, with which it lashes the water in every direction; and any animalcule thus caught remains attached to the whiplike filament, which then contracts into a spiral and disappears slowly into the pseudopodium. An appearance something like a mouth is then described, into which the particle of food is now drawn; but I think the description as given us by Carpenter will certainly apply equally well to the extemporaneous manufacture of a mouth to order, as seen in the true Amœba; and certainly, after what we know can be accomplished by sarcode in the Infusoria, and as we shall see by and by in the Sponges, we must not be surprised at its wonderful performances in the Rhizopoda. This remarkable substance, called by Carpenter a "protoplasm," does, in fact, seem to unite within itself some of the powers which, in higher structures, we can demonstrate to depend upon nerves, muscular fibre, organs of circulation, digestion, and even of sense. It is held by many naturalists in the present day, that this "protoplasm" is differentiated in the higher animals into the several organs I have mentioned.

The first thing that strikes us as remarkable, when looking at a drop of water through the microscope, is the ease and grace with which the animalcules move about. This motion is due, we have seen, to a beautiful series of organs termed cilia. Now these cilia move at a rate which is inconceivable to the faculties of the observer, and they do this under the direct operation of the will of the creature, for they work or remain quiet as it chooses. Here, then, we have motion, and the power of exciting or stopping such motion. But still more remarkable, the next thing we notice is the exercise 
of a special sense or its equivalent, viz., sight, for these animalcules rarely hit against each other. A human being under the circumstances would be knocked about and killed; but the little speck of sarcode, only the 500th or 600th part of an inch in diameter, avoids all collision, and moves about among the crowd in safety. Then we have seen that there is a water circulation which aerates the sarcodal juice - a process of digestion, and four or five different modes of reproduction. All this, as far as we at present know, results from powers inherent in this "protoplasm" or sarcode.

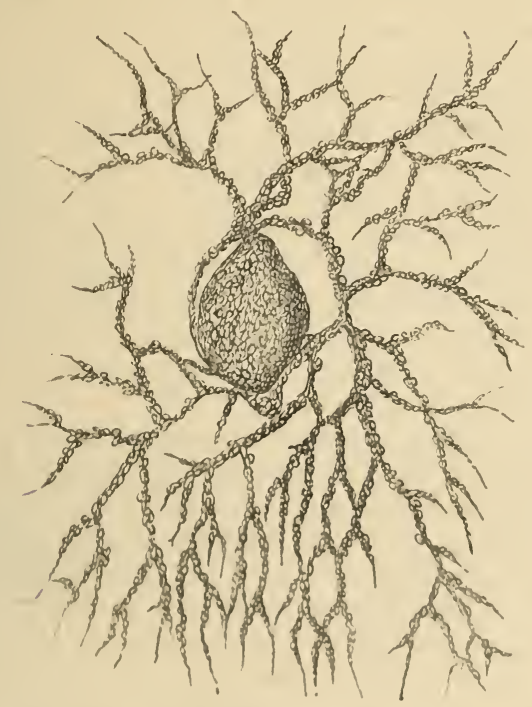

Fig. 39, - Lieberkühnia Wageneri, magnifled about $2 \mathrm{s0}$ diametors (after Claparède).

Now, the next eximple of the Rhizopoda which we come to will show the powers of this sareorlo in another light. for wo shall actually see it converting a portion of its own body into a net by which it catches its prey. The examples of Amobal we have noticent belong to the naked division of the group. We will now deal with a tramsitional gronp betwoen the naked and testaceous forms, called Retienlaria, from the fact of their being able to produse the net allueded to. One of the most beatiful individuals of this group is that discovered by M. Claparide. and eallod by him Lidberkihmid II ingentri, after two great naturalists. I have given a roduced copy 
of Claparède's figure of this creature at Fig. 39. It will be noticed that a large branch of sarcode appears to grow out of the body of the animalcule, and divide and subdivide until it attains the length in some instances of ten or twelve times that of the body. Whenever these rootlike processes or pseudopodia meet, they unite together, and then a net is formed of considerable size. When the prey of the animalcule, which may be a near relation or one of the Algæ, comes into contact with the net, it sticks there ; how it sticks, or why, I do not pretend to say, but that it does so is quite certain, and, whatever it may be, its race is run, for the sarcode net immediately takes it in-not to show it hospitality, neither to draw it down to its respected parent who formed it into a net, but actually in the most selfish manner possible to digest it itself. And now we find out in earnest that Mr. L. Wageneri is an arrant impostor, for he has actually converted a part of himself into a net, which seizes, devours, and digests its prey in that form, while he remains quite still at the bottom of the drop of water. The digested food then becomes common property, and feeds the general corpus of $\mathrm{Mr}$. L. Wageneri. This animalcule is 1-400th of an inch in size; with its net, 1-100th to 1-40th of an inch. Now it will be found that the outside skin or ectosare of these Reticularia is harder than that of the naked Amoeba. It is not at present, however, in any degree like a shell covering.

But following out the gradual development of shell in these creatures, without for the moment attending strictly to classification, or stopping to discuss the question whether an Amoba with long processes is higher in the scale than those with short ones, let us look at the next group which this mode of investigation will bring before us. The curious-looking thing shown in Fig. 40 belongs to the genus Difflugia, and here the body is covered with what is called a "test" - the word "shell" being reserved for those made of calcareous matter. This "test" is thought to resemble the chitine which forms the external skeleton, such as the elytra, of beetles. I am, however, strongly inclined to the opinion that this is only a guess, as we have no evidence that the "protoplasm" has yet been differentiated into chitine. The pseudopodia, short and stumpy, are seen in these species protruding in a supper-seeking attitude from the mouth of the test. Fig. 41 shows an example of another genus, Arcella, which carries its test upon its back. Note here also the short stumpy pseudopodia possessed by this creature. you cut off a small piece of the end from one of these organs, it will become developed forthwith into a test-carrying Rhizopod, like its respected parent; and the same with Difflugia. And mark, they never make a mistake-that is to say, the bit of Arcella never is 
developed into a Difflugia; nor does the portion of the latter ever become an Arcella. This is a much more important fact, as bearing upon the great question of the origin of species, than appears at first sight.

The stamp of individuality is affixed to the speck of sarcode by its Creator for ever. We shall presently find the Amœba among the earliest animals in time; first, in the oldest known rock; then a mighty architect in the secondary geological epoch; and thirdly, unaltered and unchanged in the stagnant ditch or the great ocean

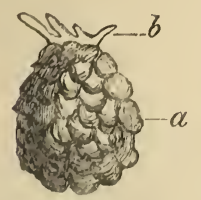

Fig. 40.

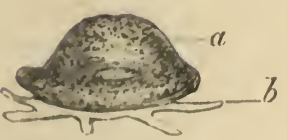

Figg. 41 .

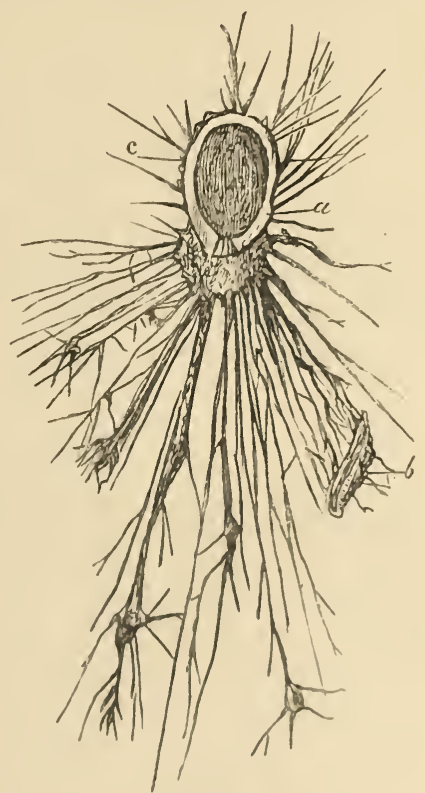

Fig. 4:.

I'ig. 40,-Dịllugia globosa, highly magniflerl (after Ehreuberg), $-a$, test $-b$, pseudopodia. H'lg. 41. - Arcella vulyuris.

Fig. 42.- (iromin oviformis, highly magnillod (after Schultzo). $-a$, test $-b$, diaton caught iu pasendopodin $-c$, satreulo covoring outsilto of tost.

of these our own days. After Arcella I would direct attention to Fig. 42, which shows a typical form of the genus Gromia, sending forth its long processes, and forming a net, just as we saw was done by the magnificent /. Wuegeneri. Observe that the test is also covered hy an extension of the pseutopodial sarcode, and from this other tilaments aro sent out. 
At $b$ an unfortunate diatom has got caught, and it will be noticed that the sarcode is concentrating laround him; he will speedily be covered in, digested, and his siliceous shield sent forth for the examination of future Grevilles, who, many thousand of years hence, find it in the field of their microscopes.

In the next chapter I shall deal with those species of Rhizopoda which have the power of forming real shells, of calcareous or exceptionally of arenaceous texture, which are included under the term Foraminifera-organisms of great beauty and absorbing interest.

\section{CHAPTER IV.}

\section{The Rhizopoda (continued).}

THE History of the root-like footed animalculæ known as the Rhizopoda, and of which I illustrated the typical forms in my last chapter, is one of surpassing interest to the naturalist, the biologist, and the geologist. More especially is this true with respect to the group to which I will now draw attention.

\section{The Foraminifera.}

The simple sarcode Amoba, as we have seen, have wonderful powers of transformation. They can adopt most singular means for securing their prey, and they are endowed with the power of secreting an outward skeleton or covering to protect them from the numerous dangers to which they must be peculiarly liable. The latter power is exercised in its maximum in the Foraminifera, which are covered with hard calcareous or arenaceous shells, moulded into forms of great beauty, and containing internal arrangements of wonderful complexity. In this group, too, we get out of the minute microscopical series which have hitherto engaged our attention ; for although some of the Foraminifera are as small as any animalcule we have examined, yet they pass upwards gradually from such a size to that of a shilling among living species, but much larger in those which are fossil, while many of the most interesting specimens can be gathered from seaweed or sand by means of a pocket lens only, and placed in our cabinets. The real study of the Foraminifera is an extensive one, for even Carpenter's splendid work, published by the Ray Society, is only very properly termed an "Introduction to the Study of Foraminifera." I cannot pretend, however, in this little work to go at great length into the subject, but shall content 
myself with, I hope, exciting sufficient interest to induce some at least to pursue it further.

Until the last thirty years the Foraminifera were classed as mollusca, and were placed with them in conchological works. In 1826 M. D’Orbigny, a celebrated French naturalist, published a monograph upon the family, and was the first to bring them into anything like scientific order, but he still regarded them as mollusca. It was in 1835 that Dujardin, to whom we are indebted for many valuable discoveries among the lower forms of life, particularly those assumed by the protoplasm, to which he gave the name of sarcode, turned the attention of naturalists to the fact that the shells of the Foraminifera, were secreted by the Amoba. Subsequent investigations by both Continental and British histologists have fully confirmed this discovery, and the works of Williamson and Carpenter, published by the Ray Society, have brought together and added to their own most valuable investigations all that is known up to, I may say, the present day about these most remarkable Protozoons. Other and original investigators have, however, added much to our knowledge of the Foraminifera, among whom Dr. Wallich in this country stands pre-eminent.

The shells of the Foraminifera liave three distinct types of texture. They are for the most part calcareous; in fact, Dr. Carpenter thinks they may all be considered as essentially formed of calcareous matter. Their appeurance, lowever, is that of three distinct types -first, those in which the shell has the external character and glossy look of porcelain; secontly, those in which it has a hyaline or glassy appearance; and thirdly, those in which it is formed of sandy particles, which aro agglutinated together by a peculiar secrotion from tho animal, and into the composition of which some, but little, calcareous matter enters.

Tho shells which exhibit these different kinds of texture are not divided into groups by reason of their texture. In fact. many of them are partly hyaline and partly poreelinous, or they may be the former when young (Fig. 56, p. 1\%), and the latter when old (Fig. 5.5. p. 42). They mity ho samly in texture, as in ligs. 1:3, 57, and 6i: (p. f2), but there are porcelanous and hyaline shells of the sime shapo, and in the samegrenus, as tho spiral shown at Fig. (iis (p. fe). In Figs. $51-51$ (p. 12), the texture is what is called sub-hyalime. that is, having a tendency to the porcelain form, which in Fig. 51 $(p, 42)$ is seen in all parts of the shell, except the riblge and anterior portion of the segments.

I have said that the creature that forms these shells is the Anuba. This is proved by dissulving the shell in weak acil. when its oceupant is fouml to be a cast of the shell, and to be nothing 


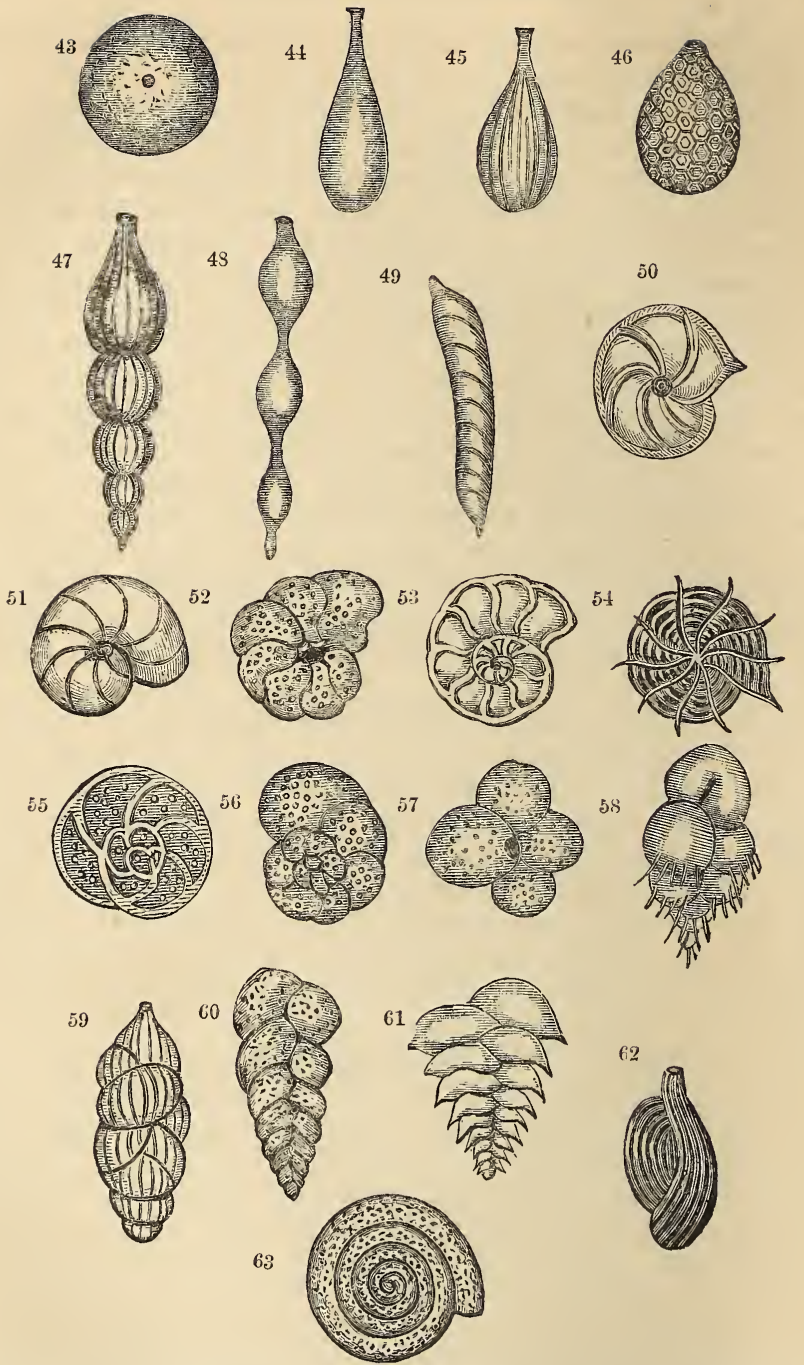

Figs 43-63.-Groups of Foraminifera.-43, Orbulina universa; 44, Lagena vulgaris; 45, ditto, var. interrupta; 46, Entosolenia squamosa; 47, Nodosaria radicula; 48, Nodosaria pyrula; 49, Dentalina legumen; 50, Cristellaria calcar; 51, Nonionina Barleeana; 52, Jeffreysii; $53, N$. elegans ; 54, Polystomella crispa; 55, Rotalina concamerata (mature); 56, ditto, young 57, Globigerina bulloides; 58, Butimina Pupoides, var. spinulosa; 59, Uvigerina pygmæa? 60, Textularia variabilis; 61, T. variabilis, var. difformis; 62, Miliola bicornis, var. elegans'; 63, Spirilina arenacea. 
more than the sarcodous animal we have demonstrated as Amœba (Fig. 67, p. 46). In by far the largest number of shells, viz., those which are hyaline, their true character is also shown by the pseudopodia being projected through minute orifices or perforations in the shell, as seen in Fig. 64, and hence the name of Foraminifera. In the porcelanous group there are no foramina, and the pseudopodia are emitted from the mouth of the shell, as seen in Fig. 65.

Such being the texture, let us now look at the forms which they assume. I have selected as typical examples twenty-one of these shells for illustration (Figs. 43-63). These will be admitted, I think, to be very beautiful objects. They remind us, in fact, of works which, as specimens of art, are endeared to the memory of the classic scholar. We have in these bottles (Figs. 44, 45) the origin surely of the Roman lachrymatory, in which the tears of departed friends were supposed to be kept. They are clear as glass, looking as like bottles in fact as they can do, as is shown in Fig. 66, in which the animal is seen through the transparent shell, while Fig. 46 is hyaline everywhere except the central white parts of the hexagonal reticulations on the surface, which are porcelanous. Now look at Fig. 49. Who had the first start, the pea in making its pod, or the Amoba in making its shell?

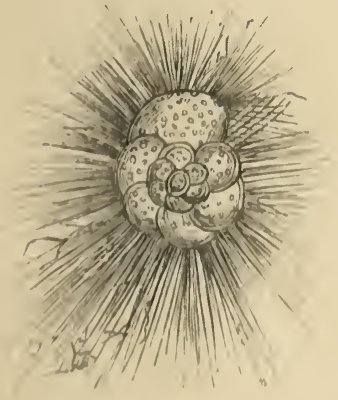

Wig. 61.

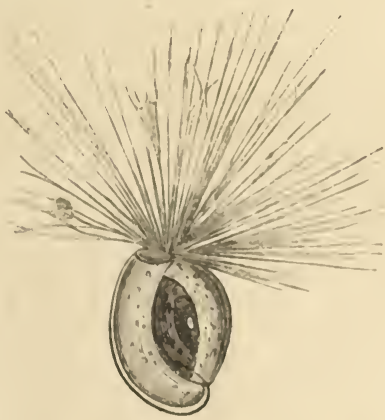

Fig. 65.

Flg. 61.-Discorbina globularis (ufter Schultzo).

We will not now argue this abstruse question, although, of course, the Darwinians will give it in farour of the pea ; for, irresistibly as it were, the imagination rushes to the old corme cmmonis-which, in very olden timos, was thought to be like the ram's horns which ornamented the statues of Jupiter (Fig. 511). Gro on a little. and when you see Fig. 51 you must, whether you will or no, think of the fairy nantilus gliding with graceful beauty over the surface of 
the deep, deep sea, or the cornucopia which the fairies of ancient Greece used to fill with flowers. In the words of Dr. Williamson, when dealing with these shells, we may exclaim, "Imagination may long revel amongst these lovely creatures, ever finding abundant scope for the play of fancy; and should any one still exist in this nineteenth century who is disposed to frown upon such objects as unworthy of serious study, let him submit to be reminded that in nature, as well as in art,

\section{A thing of beauty is a joy for ever."}

Now the mode in which these shells have been formed has been well studied, and is well known. It is the simplest thing in the world, for it is nothing more in the great majority than a process of budding. It is done in this wise : Suppose Fig. 45 (p. 42), which is a Lagena, were to propel a bud from its base, which were to grow straight downwards, and reach about half the size of the maternity (Fig. 45), and then propel another bud, which also grew to half the size of its mother, and so on, for two more instances-why it is quite clear, that you would have a figure exactly like Fig. 47 (p. 42), which is no longer a Lagena, but a Nodosaria. Now suppose that the second node in Fig. 47 were an independent Foraminifer-and there are many such-and it were to develop a succession of buds like those I have described, which, instead of growing down straight, were to deviate to the right or the left; the shell, when completed, would have the discoidal shape shown in Figs. 50-56 (p. 42). Or look at the Figs. 58 to 61 (p. 42 ) ; suppose the largest segment to be the original germ, and the others gemmæ therefrom in the way I have described, and the mode of formation of these shells will be quite intelligible. A different mode of growth is adopted by the nonporous group, represented by Fig. 62 (p. 42), the Miliolinæ. In these shells each chamber is of equal length and formed after the fashion of a piece of thread round a ball. The orifice is therefore alternately, as the bud is perfected, at each end of the shell. In Fig. 63 (p.42) there are no partitions, either outwardly or inwardly; the shell, which attains the size of one-fiftieth of an inch in diameter, is a simple cylindriform tube, coiled upon itself on a horizontal plane, and is perforated with numerous foramina, through which the pseudopodia extend. Fig. 57 (p. 42) represents a curious family, in which the buds have no communication with each other, though attached by their external shells. Dr. Carpenter suggests that if we imagine one of these prolonging itself in a spiral form, it would become a shell like that seen in Fig. 63 (p. 42). If the sarcode body, as stated before, be separated from the shell, it would in many species be a cast more or less of each of the chambers, which freely 
communicate among themselves (Fig. 67, p. 46). In others, this communication is by no means so perfect, and we have seen an instance above (Fig. 57, p. 42) where there is none at all. It is observed that in those species of Foraminifera in which the shell is perforated, the sarcode being able to obtain nourishment by its pseudopodia, the segments are more independent, as it were, than in those species in which the pseudopodia are projected from the mouth alone (Fig. 62, p. 42, and Fig. 65, p. 43); while in others the foramina in the shells are the orifices of a series of canals which ramify through all the chambers, bringing the innermost whorl into direct communication with the external world.

But the organisation of some of the Foraminifera is still more complicated. Without going minutely into this most interesting subject, I will give an example, the details of which may be easily followed: Take a shilling into your hand, and place it with the Queen's head (God bless her!) upwards. Now imagine that the letters were carried all the way round the rim, and that instead of the Queen's head the upper surface of the shilling were filled up with circles of letters, each letter opposed to the space between the lotter of the previous circles (cabbage-planting fashion). These circles would, of course, ultimately end in a single letter in the centre of the shilling. Now imagine further that if each letter in the outside circles were to send forth a canal towards the centre of the shilling, this would strike the space between the letters of the next circle in the middle. Well, let this canal be supposed to divide at this point, and to send forth branches directly to the two letters on each side. Suppose further, that the edge of the shilling liad circular openings, about one-third of its depth from the top, in the sulci of the milling on the elge of the shilling, and that they were the openings of canals which went directly to those between each letter in the first circle on the top of the coin.

Now, instearl of a shilling with letters, imagine a circular shell having its shape and milled edge varying from 1-30th to 7 -10ths of an inch in diametor, and each letter a lump of sarcode connected with each of the others in the way I have pointed out by canals containing sareole, and that throngh each hole in the milled edge of the shell thero issmed a series of psendopodia, also formed of sarcode. like those in Fig. (i.t (p. 4:3), and you have an exact representation of a compound animal, or scries of comnected Protozoons; the whole being nourished by the proy eamght by the psendopodia coming ont of the formina in the rim, which animal, living in its componme shell, is known as one of the genns Orlitelites (Fig. 67. p. 46).

'This singular organism is eleveloped by a series of budelings from a "entral dise," an Capenter enlls it, which is beantifully 
figured in all stages of the shell growth in his truly magnificent work on these creatures. In the centre of each shell there is found a single somewhat pear-shaped chamber ( $b$, Fig. 67 ), and a larger one immediately surrounding it.* From this chamber a series of canals are sent off, terminating as shown above in a chamberlet, as it is called, which is represented by the figures on my shilling; and the first zone being then formed, the pseudopodia enable the animal to increase the shell outwardly until it attains in some instances, as I have before remarked, nearly one inch diameter. It is possible, by decalcification with a weak acid, to remove the shell, and leave the
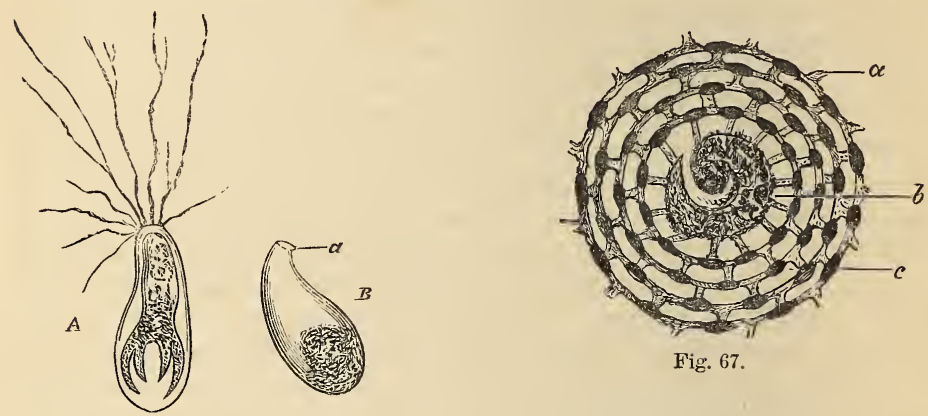

Fig. 67.

Fig. 66.

Fig. 66.-Lagynis Baltica (after Schultze), highly magnifled. A, animal expanded, and pseudopodia protruded from mouth $-B$, animal contracted into the bottom of shell$a$, mouth.

Fig. 67.-Decalcified sarcodous animal of Orbitolites $-a$, the sarcode which fills the canal opening in the edge of the shell through which the pseudopodia are emitted $-b$, the central sarcode or amoba forming the animal of Orbitolites-c, the segments of sarcode connected with each other and with the central sarcode by the various canals. In the shell the space occupied by these segments is called a "chamberlet."

sarcode animal in situ. It will then have the appearance shown in Fig. 67. The arrangement of the canals and the individuals which make up the compound animal is well shown. The pseudopodia proceed, as I have described, from the annular passages between the outer row of segments, as they are called. In due season these pseudopodia will form another concentric zone-like that from which the canal (a) proceeds - which will then, in like manner, be transferred to the edge of the new formation; and so the Orbitolites will increase in size.

* I have not thought it necessary to give a figure of the shell, which is of course an exact impression of Fig. 67. This must be borne in mind when I am describing the chambers of the shell. 
This is the simplest form of Orbitolites; there are others found in large quantities in the dredgings on the coast of Australia, in which the structure is much more complex. It does not enter into my plan to give details of these forms. I have said enough to give a general idea of how the Foraminifera are constructed. There is a great deal of most interesting matter contained in Drs. Williamson and Carpenter's splendid works before mentioned, and to them I must refer those who wish to extend their studies of these lowly forms of life. The student has one advantage not attained in the Protozoons I have previously dealt with, viz., the Foraminifera are many of them large enough to be picked off seaweed or out of sea-sund, with the aid of a moderate lens, and preserved in our cabinets for examination. But they will not be found in any number on the shore. They live in deep water, and sand or weeds for examination must be obtained in two or three fathoms. The following is Dr. Williamson's directions for securing specimens: "If the collector merely seeks dried shells for his cabinet, indifferent whether living or dead, the process of floating them is by far the most productive. A fow pints of the sand must be collected from beneath at least two or three fathoms of water, and thoroughly dried; it should then be passed through a conchologist's sieve, or coarse net, so as to eliminate all the rough material. The finer portions passed through the sieve must be poured into a bowl containing cold water, and well stirred up, so that the whole may be saturated. On being allowed to stand a few moments the more delicato of the concamerated shells, rendered buoyant by the air contained within their chambers, readily float to the surface, while the sand and mud settle to the bottom. (Be careful at this stage to burst all air bubbles on the surface.) A little manipulation enables the collector to blow off this scum so rich in treasures, and the addition of fresh water cleans them; the creaming of the bowl being repeated as long as any sedinent or impurity remains. The water may be now drawn off by a syphon, and the objects dried, when they are easily collected for examination."

Dr. Williamson earries this process a step further, in order to get the cleanest specimens. Sweeping the sides of the bowl with his forefinger, he transfers them to a small evaporating dish, aml boils them in liquor potassa over a spirit lamp for somo moments. thus dissolving organic matter, and leaving the shells free from impmity. The solution must now be poured off. and the shells. which sink to the bottom, washed in cold water, and again dried for examination.

When, however, the specimens are wanted living. Dr. Willimmson points ont that the mode of collecting them must be 
exactly the reverse of that above described. They must either, where the coast sand is coarse and gravelly, be picked off the corallines (whose zone, by the bye, is their especial home) or seaweeds. When the bottom is muddy and fine-grained, "the mud is to be put into a vessel containing water, and well stirred up. The fine inorganic particles are floated off, whilst the shells, from their greater density and larger size, sink to the bottom; a repetition of the washings leaving them perfectly clean."

Such is a slight sketch of the Foraminifera in space. But they are still more interesting in their fossil condition; and as it is here that their true position in the physical history of the world can be best studied, I will devote my next chapter to a consideration of "Foraminifera in Time."

\section{CHAPTER V.}

\section{The Foraminifera in Time.}

OtrR path now lies for a season in the crust of the earth. We must look into that mighty record of the past for proofs that the sarcode Amoba was a creature ultimately designed by Omnipotent power to build up the solid portion of the world which man was destined to people. It has been the province of very recent investigators to prove that the Amœba is the oldest of known fossils; that it was the architect unconsciously working away at a period so remote, that we can only realise it in any intelligible form by comparing it with the space we are told to think of, supposing the nebulous matter which is resolved into stars by the high power of Rosse's telescope reveals to us suns which are the centres of systems like our own. For years past we have been told by geologists that the venerable relic known as Oldhamia antiqua, figured and described in Mackay's "First Traces of Life," and found abundantly in the Lower Cambrian rocks, was the oldest of fossil forms. But geology is a progressive science, and each year adds something to our knowledge of that record which tells us of primeval fungi or most venerable Protozoa. Sir Roderick Murchison and Professor Sedgwick, having spent the best part of their valuable lives in establishing the true position and developing the geological history of the Silurian and Cambrian rocks, find now other investigators are going beyond them, and placing still lower systems than theirs among the fossiliferous strata of the earth's crust. 
To those who are unacquainted with geology, I may remark briefly that, although the entire solid crust of the earth has been calculated by Mr. IIopkins to be not less than 800 or 1000 miles thick, there are only about nineteen which are known to geologists as sedimentary-fossiliferous rocks-that is to say, rocks which have been deposited from water in different periods of the world's history, and containing preserved within their beds the remains of some of the living things which existed in those waters.

Now this nineteen miles of sedimentary rocks may be broadly divided by the character of their organic remains, so as to represent four nearly equal divisions. The first of these from above downwards-which is, of course, in order of age, the fourth periodcomprises-1, all recent formations, including those strata called by some geologists Quaternary; 2, the Tertiary formations; 3, the Cretaceous, or Chalk group ; 4, the Jurassic, so called because they are typically developed in the Jura Mountains; 5, the Triassic, corresponding to the upper new red sandstone, which is readily divisible into three distinct groups-hence the name.

These strata are called Neozoic, because the life which is represented as having existed is "newer" than that which precedes it. Till recently, and even now by many geologists, the term "new" is confined to the recent and tertiary formations, under the term Cainozoic; while the secondary strata, from the chalk to the lias, are called Mesozoic (middle life).

The third division comprises - 1, the Permian or Magnesian Limestone; 2, Carboniferous, or Coal measures; 3, the Devonian : and these strata are called Upper Paleozoic (old life).

The second division includes - 1, Upper Silurian; 2, Lower Silurian; 8, Cambrian. These form the Lower Paleozoic.

The first division or period, called till recently the $A$ \%oic (without life), includes the oldest known sedimentary rocks, "the Laurentian," which are doveloped largely in Canada and the United States, and are also found in Ireland, Scotland, and Devonshire. The above arrangement will appear more clear from the following table : 


\section{THE EARTH'S CRUST.}

\section{Fossiliferous}

Strata.

Fourth Period,

Neozoic

(New life).

$4 \cdot 512$

miles thick.
Third Period,

Upper

Paleozoic

(Old life).

$4 \cdot 458$

miles thick.
1. Recent.-Including Quaternary

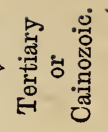

2. Tertiary.-Pliocene, Miocene, Eocene...

3. Cretaceous. \{Maestricht beds, chalk,

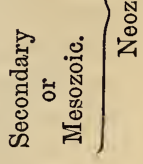

4. Jurassic.-Oolites and Lias.

5. Triassic.-Upper, middle, lower Trias...

(1)

6. Permian.-Magnesian limestone

7. Carboniferous. $\left\{\begin{array}{l}\text { Coal measures and car- } \\ \text { boniferous limestone .. }\end{array}\right.$

8. Devonian.-Upper and lower

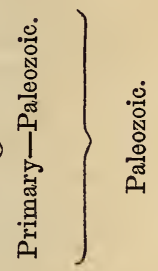

Second Period,

Lower

Paleozoic:

5.082

miles thick.

9. Upper Silurian

10. Lower Silurian

11. Cambrian

$$
\text { (1) }
$$

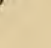

First Period, Eozoic

(Dawn of life) $5 \cdot 670$ miles.

12. Huron

13. Laurentian
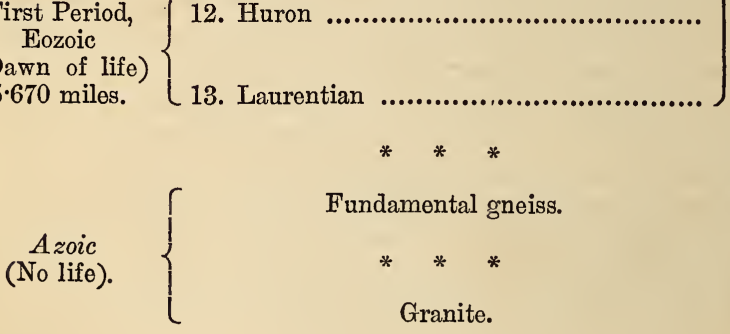

Fundamental gneiss.

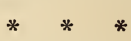

Granite.

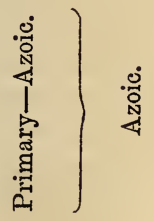

Total known thickness of the earth's crust containing remains of organic life, 19,722 geographical miles. If the present estimate of Laurentian rocks being 90,000 feet thick turns out correct, this amount will be increased to 31.062 miles.

The estimate of the entire thickness of the earth's crust arrived at by Mr. Hopkins, from data furnished by the effects of the sun and moon's attraction as indicated by the rotation of the earth's axis and the precession of the equinoxes, is from 800 to 1000 miles. 
Now, beginning with the first fossiliferous period, which I propose to term "Eozoic," as used in the above table, we find that these Laurentian rocks, composed of quartz, slate, and limestone, forming in many parts a beautiful veined green marble, occupy in Canada and New York an area of 200 square miles, and have a known thickness of 30,000 feet, and an assumed one of 90,000 feet, or, as Sir William Logan has suggested, a thickness which "may possibly far surpass that of all the succeeding rocks from the base of the Paleozoic series to the present time, carrying us back to a period so remote that the appearance of the so-called primordial fauna may be considered a comparatively modern event."

This extraordinary formation has been recently proved to have been formed almost entirely by Foraminifera. In other words, the rocks are the remains of the shells of one of these animals, to which the name of Eozöon Canadense has been given. This discovery, one of the most interesting and important that geological science has afforded us, was made by Sir William Logan, the Superintendent of the Canadian Survey, and Dr. Dawson, the Principal of McGill College, Montreal, guided by the information given them in Dr. Carpenter's "Introduction to the Study of Foraminifera." The details of the subject havo been worked out with great care by Dr. Carpenter himself, who published in the Intellectual Observer for May, 1865, a most valuable and interesting paper, illustrated with coloured and tinted plates, giving the history and showing the structure of this interesting fossil. To this memoir, and to one by Dr. Rupert Jones, in the Popular Science Review for April, 1865, and also to the papers of Dr. Dawson in the Journal of the Geological Society, rol. lxxxi., page 51, and of Sir W. Logan, in page 48 of the same journal, I must refer those who wish to know more than the limits of this work will permit me to say.

The Amoba which formed the shell of the Eozöon Canadense in those ancient waters was at least twelve times the size of any known living species of the present day. And if you will be good enough to refer back to my illustration of Orbitolites in the last cliapter, and imagine it to be a foot in diameter, and thickened proportionately by placing one disc above another, you will obtain for all practical illustration an idea sufficiently comprehensive of the representative of the oldest living thing in the history of the world. And should you ever hereafter bo sailing on Lake Huron, or wandering among the Canadian scenery watered by the St. Lawrence, it will be as well to bear in mind that for that portion of the earth's crust we are indebted to tho labours of myriads of amobiform ereatures who have left their remains as a mark of the service which they have done in earrying out the great scheme of nature. 
It is not known as yet if any other animal lived in those ancient seas. On this subject the stone book is silent. There is, however, no decided proof that other animals may not have existed coeval with the Eozoon, although their remains are not found in the Laurentian rocks. They may have been destroyed by the heat, which metamorphosed the sediment of those seas into Labrador felspar, hypersthene, crystalline limestone, and beautiful green veined marble, but which left intact the cast of the Foraminifera, and so perfectly that the fossilised pseudopodia may be seen like tufts of silver wire radiating through its canals and chambers.

For the time being, then, at least, the Eozöon Canadense must be considered as the oldest example of organic structure which the records of geology have revealed to us; and we must receive as a fact of science that the lowest known sedimentary strata, for the depth of from four to sixteen miles round the earth, have been formed by the lump of jelly called the Amoba. The student will note that although these Laurentian rocks have only been observed, say, in North America, Ireland, Sweden, \&c., yet the geological inference is that they would be found to occupy the same position in all other parts of the world if the more recent formations were removed. Thus, were I to bore into the crust of the earth at Colchester, I should expect, at a distance of $13 \frac{1}{2}$ miles, to come down upon the Laurentian rocks. At the time of their deposition it is probable there was no land anywhere on the face of the globe, which was one vast sea until the disturbing forces of central heat from time to time kindly upheaved masses of land, which in his own time the Creator peopled with living things.

There is something truly practical and satisfactory in the revelations of a science which shows to us how gradually the crust of the earth was built up, and how far down that vista of time, in which the imagination may revel in awe and wonder, those mighty preparations were begun which culminated in the creation of man himself.

In the second or Lower Paleozoic period, Foraminifera have been detected by Ehrenberg in the green grains which occur in the sandstone near St. Petersburg; and, what is remarkable, there are many of them referable to genera-if not species-now existing in our seas. But the Foraminifera are not now found alone, on the contrary, they are associated with animals belonging to all the other sub-kingdoms.

There are no less than nine classes of animals found in the strata immediately above the Eozoic; but then we cannot now, as we did yesterday, reason upon these animals as existing in the first dawn of life. The discovery of Eozöon Canadense makes the fauna of the Silurian system, comparatively speaking, modern, although the 
creatures comprised therein, existed in seas whose deposit, five miles in thickness, is now at least nine miles more from the surface of the earth.

In the third geological period the Foraminifera are still found at work. In the carboniferous limestone there are beds formed entirely by a genus called Fusulina, which seems to have come into being and gone out of it in this period of the earth's history, as it is no more found in its crust, or in the waters of our time.

$\Lambda$ s the name implies, these Fusulina are spindle-shaped, as shown in Fig. 68, which is a cast of the chambers of the fossil. If cut transversely across, a section will show its internal structure, as seen
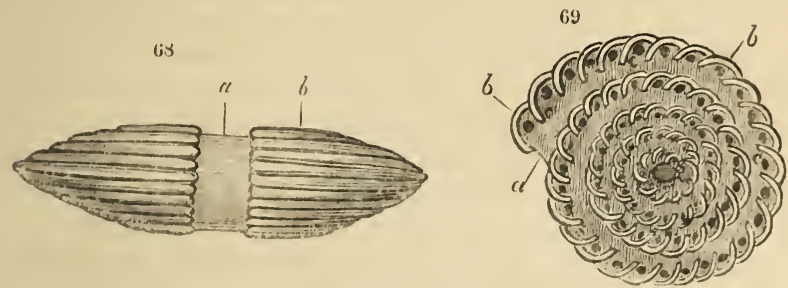

Fig. 68.-Cast of the chambers of a Fusulina of simple type (after Ehrenberg) - $a$, median segments $-b$, alar prolongation.

Fig. 69.-Transverse section of the centro of a Fusulina (after Carpenter), showing $c c c$, the principal chambers $-a$, tho communication between tho chambers $-b b$, dark spots indicating tho origin of the alar prolongation $(b, 68)$.

in Fig. 69, which is very similar to that of Nummulites, a genus existing in enormous numbers much more recently. Two other genera of Foraminifera are also found associated with Fusulina in these carboniferous limestones, viz., Rotalia and Textularia, both of which have many living representatives in our own seas, and examples of which were included in my last chapter (Figs. 55, 56, (60), 61, p. 42).

$\Delta t$ the end of the third geological period (see table) the form of life appears to have undergone a great change, as we shall find more particularly by and by. In the Iower Paleozoic, crustaceans reached the highest amount of development, forty to overy mile of rock. In the Upper Paleozoic, fishes commence that renarkable numerical development which reaches its highest point in the Jurassic-27() per mile. Reptiles, but little known in the Paleozoic, make a wonderful advance in the Neozoic, and attain their highest range in the Triassic-over 90 per mile; whilst mammals, commencing in the Jurassice, where they are represented by seron species per mile of rock, disappear entirely in the Cretaceous, and in the 'Tertiary are found in the proportion of 34 to every mile of rock. There is thus 
altogether a great increase in the number of species in at least three out of four of the classes I have mentioned in the Neozoic period. But they not only increase in number, but in diversity and character. Thus, any one seeing a Paleozoic fish or reptile, who is acquainted with the subject, would recognise it from any part of the world as such, but he would have a difficulty in separating those found in one part of the world from those found in another; whereas, as Professor Haughton remarks, "in the Neozoic period each bed of rocks and, I may add, each particular country, has its peculiar and characteristic fossils, which are easily distinguished from fossils of other parts of the earth formed during the same time."

With the Foraminifera, however, there has been but little change in time. Messrs. Rupert Jones and Parker have described a bed of clay at Chellaston as being almost entirely formed by the genus Rotalia. This clay belongs to the Upper Trias, and we have just seen that the Rotalia were associated with the Fusulina in forming the Russian limestone in the Coal period. The same shells are found in the Jurassic and Cretaceous systems, and are very abundant in the crag on the Essex and Suffolk coasts. My figures were from species existing in our own seas. The genus Bulimina is also found in the Upper Trias and all subsequent strata. It occurs abundantly in our seas, and I figured recent species of it in the last chapter (Fig. 58, p. 42).

It is, however, in the Cretaceous group of strata that the Foraminifera begin to appear most abundantly. It may surprise many of my readers when I tell them that the chalk cliffs throughout the world consist mainly of the remains of Foraminifera. We cannot go when we will and examine the stupendous Laurentian rocks, but we can visit our chalk cliffs at Dover, or wander over our Sussex downs ; and we can also realise the great use to man of chalk, when we see our farmers spreading it upon their stiff clays; and we can without much trouble follow the "white hills" into Ireland and Spain, France and Greece, for an extent of 1140 miles. We can follow them from the south of Sweden to Bordeaux for 840 miles, and we can measure these cliffs, and find them to have a thickness of from 600 to 1000 feet; and then we can sit down in some snug corner, and smoke our pipes, and ponder upon the wonderful fact that all the most important parts of our earth's crust have been built up by an animal, sometimes so small as only to be seen through the microscope-a creature without muscle, bone, nerve, or blood vessel - a mere lump of jelly!

But our inquiry is not yet over, for we have been into Egypt and seen the Pyramids. "What of that?" I can fancy I hear one of those sceptics, who never will see anything in anything, cry out, 
"What of that? We have you there. You do not mean to say that your 'what-d'ye-call-'em' built up those splendid monuments?" Stay awhile, my friend, and it may do your scepticism good to listen for a moment. My "what-d'ye-call-'em " did more than build the Pyramids-they made the stone! If you doubt this, take a trip there next summer, and you will find the stone composed of vast numbers of rounded discs, which were described by the old writers as fossilised lentils used by the workmen who built the Pyramids, and thought to be so until Strabo pointed out that it could not bo true, for there was a hill at Amasia, in Asia Minorwhere he lived-stretching out into a plain entirely composed of similar lentil-like bodies (Geog., lib. xvii., p. 808, Paris, 1620). And this has been proved correct by modern geologists, as we are told by Dr. Carpenter that M. Tchihatcheff had brought from Amasia splendid specimens of the well-known Foraminifer-Nummulites-so called from its " money-like" appearance; for if you were to cover a shilling on both sides with a layer of smooth calcareous matter, you would make an exact representation of the fossil Nummulite.

I began this history of the Foraminifera in Time by a statement which looks more like a fairy tale than a strict scientific fact. I went back into the "dawn of life," and showed how the Amœba had built up rocks of marble hundreds of miles in extent on our earth's surface, and of a thickness known to be five, assumed to be fifteen miles. I shall close it by an account still more remarkable, viz., a brief sketch of the history of the Nummulite.

If you will look at the geological table, you will obserro that the second group of strata (tho Tertiary) is divided into Pliocene, Miocene, and Eocene-expressive of their position in time.

Now, at the beginning of the Eocene period, and contemporaneously with the London clay and Paris basin formation, we first observe the appearance of the Nummulite. It reached its highest point of development about the middle of the Eocene period, when at loast fifty species aro known to have existed. It then began suddenly to deelino, appeared in less and less numbers in tho liater Tertiaries, and in our seas only a single spevies is known to exist.

But in the period above indieated this little Foraminifer had formed beds of enomous thickness and great extent in the crust of the earth. Somo idea of these extraorlinary strata-known as the Nummulitic limestone-may bo gathered from the following extract takon from Professor Haughton's "Manual of Creology," pp. 176 and $177:$

"Tho geologieal distribution of Nummulites is most remarkable. 
as they are found along the entire line of mountain chains from the Pyrenees to Thibet, and occur at all altitudes, from $8000 \mathrm{ft}$. and 10,000ft. in the Pyrenees and Alps, to 15,000 ft. in the Himalaya Mountains; they form a geological zone, stretching W.N.W. to E.S.E. from $10^{\circ} \mathrm{W}$. long. to $55^{\circ} \mathrm{E}$. long., having a width of 1800 miles. Further to the east it narrows considerably, but the entire length from W. to E. embraces $98^{\circ}$ long., and its breadth from $\mathrm{N}$. to S. ranges from the 16 th to the 55 th degree of north latitude.

"The Nummulitic limestone surrounds the entire border of the Mediterranean Sea and of the Black Sea. It constitutes a large portion of Egypt and of Asia Minor. ..... It is found in the elevated regions of the sources of the Tigris and Euphrates, and extends from Upper Armenia to the Persian Gulf. It also stretches eastward from Armenia, along the valley of the Araxes, by the chain of Elburz and the plateau of Iran, as far as the mountains of Cabul and the Punjaub. It completely surrounds the valley of Cashmere, and rises in the chain of the Himalayas to a height of 15,996ft., from which altitude it descends on the south-east of the chain along the right bank of the Indus, forming the lower hills of Beloochistan. Still further to the east it is found in the mountains of Kossya, between the Brahmapootra and the plains of Bengal."

Professor Haughton says that Nummulites are not found in America or in the southern hemisphere; but this statement is not quite correct. The species of Foraminifera are not well defined; and a closely-allied form, Orbitoides-which may be taken as not differing more from Nummulites than species of the New World do in general differ from those of the Old-forms an immense bed of rock in Alabama, which is called in America "Nummulitic limestone."

I need say but little more to prove the important agency assigned to the Amoeba in building up the crust of the earth. In all this there is a vast proof of the Design with which this lowly organism was created. Take away the Laurentian rocks, and the chalk, and the Nummulitic limestone, and the crust of the earth would tumble to pieces. And yet they were formed by a lump of jelly that could only have the blind instinct of self-support and self-preservation.

And the same Design is being carried out in our time for the probable creation of a future world, in which Man himself may be the most important fossil.

The bed of the Atlantic Ocean, even at a depth of two miles, is covered by ooze teeming with Foraminifera, ninety-seven per cent. of the soundings at the above depth being found by Capt. Dayman to consist of Globigerina. They are principally found in the Gulf Stream, and follow it in its course. Does this indicate a future 
group of hills or mountains having such a range? The coasts of Australia are crowded with living Foraminifera; in fact, they are found in the soundings of most tropical seas, and the greater the depth, as a rule, the larger the specimens. They occupy fifty per cent. of the ooze in the deeper waters of the Mediterranean, Adriatic, Red Sea, Canaries, West Indian Islands, east and west coasts of South America, St. Helena, and Isle of France.
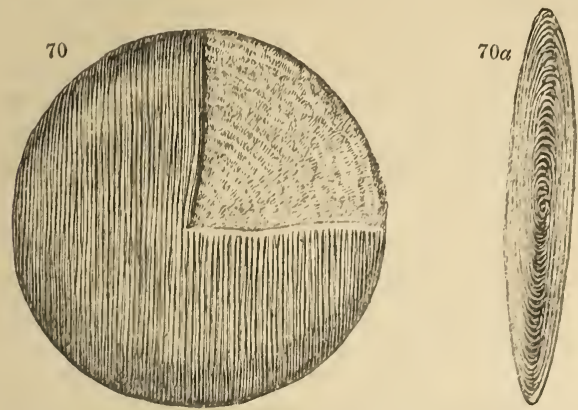

71

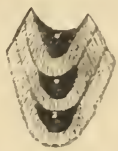

F'ig. 70.-Nummulites complanata, with a portion of calcareous covering removed.

Fig. 70a.-The same seen edgewiso.

Fig. 71.-Three separate cells, showing the minute opening (seen as three white dots in the cut) by which they communicate with each other (after Haughton).

Fig. 70 gives a representation of one of the most abundant species of fossil Nummulite, with a portion of the calcareous shell removed to show the internal structure, which, it will be observed, consists of a succession of cells, placed as in Orbitolites, concentrically. In Fig. 70 a the bevelled edge is shown. In Fig. 71 the small openings through which the cells communicate with each other aro seen.
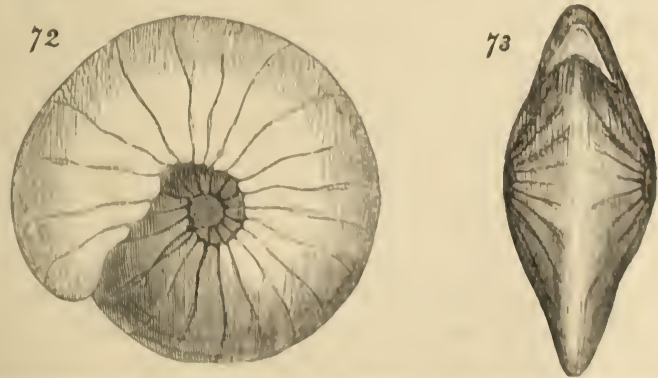

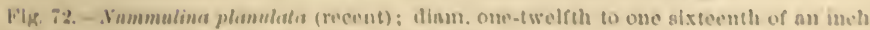

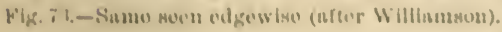

ligs. 72 and 73 represent the only known species of Nummulite 
existing in the present seas. It has been found at Portsmouth and Scarborough, and is considered by Dr. Williamson identical with fossil shells found in the Tertiary formations which were deposited in the tropical seas, inhabited by "the gavial, sea-serpents, and gigantic sharks."

The history of the Foraminifera is a part of that of the earth. I have in this paper endeavoured to show how intimately the study of animal life is connected with those higher generalisations upon which the science of geology is founded. How much is our interest heightened in that drop of water under the microscope, and that Protean lump of unsymmetrical sarcode called the Amøba, when we associate them with the physical architecture of the world, and the forethought and design of that world's Creator!

\section{H A P T R V I.}

\section{The Radiolaria.}

Few people who have not made science a study ever heard of the Radiolaria. Many even among the learned know little about a group of animals of which we have only recently known anything at all; and yet we find them placed by Kölliker higher in the scale of being than the creatures which form the shells of the Foraminifera. This exaltation does not arise, as it well might, from the exquisite beauty of their form, but rather that in the Radiolaria there is, for the first time, a departure from the unicellular character of the organism. The Gregarinidæ, the Infusoria, and the Rhizopoda, properly so called, all consist, in their mature form, of single cells. They are Protozoons-simple, as in the Infusoria, or compound, as in the Orbitolites among the Foraminifera.

It is true that, as Kölliker remarks, originally all the Rhizopoda are formed by a union of many cells, and yet each mature individual contains its cellular nucleus only.

On the other hand, the Radiolaria consist always, and without exception, distinctly of a great number of cells, or Protozoons, and so they lead us a step upwards in the scale of living things. Kölliker fortifies his opinion by other reasons.

For our knowledge of the Radiolaria we are, in reality, indebted to Professor Huxley. Ehrenberg, it is true, was first in the field, 
but to Professor Huxley is due the credit of bringing them prominently into notice in the year 1851. Since that time they have been studied by Müller, Claparède and Lachmann, Carpenter, Kölliker, and others.

Mr. Huxley, in his paper ("Annals and Magazine of Natural History," Second Series, December, 185̃1), thus describes the locus in quo of the Radiolaria: "In all seas, whether extra-tropical or tropical, through which the Rattlesnake sailed, I found floating at the surface the peculiar gelatinous bodies which are the subject of the present communication. They were the most constant of all the various products of the towing-net, which was rarely used without obtaining some of them, and which sometimes for days would contain hardly anything else." And he thus describes their nature : "The Thalassicolla (thalassa-the sea, kolla-jelly, glue) is found in transparent, colourless, gelatiniform masses of various formselliptically elongated, hourglass-shaped, contracted in several places, or spherical, varying in size from an inch downwards; showing no evidence of contractility, nor any power of locomotion, but floating passively on the surface of the water."

Professor Huxley's excellent paper was written fifteen years ago, and ho says: "The extreme simplicity of structure of these creatures was more puzzling to me than any amount of complexity would have been. The difficulty of perceiving their relations with thoso forms of life with which I was familiar gave me rather a distaste to the study of them, and, as I now perceive, has rendered my account of their organisation far less complete than I could wish it."

Since this paper was written some points which were obscure to Mr. Huxley have been cleared up, as, for instance, their power of contraction. Professor Kölliker (Icones Histiologicæ) writes: "The Radiolaria are, in all probability, a series of many-celled animals, the bodies of which consist of the contractile substance by which the Rhizopodia are characterised, and, like them, having similar pseudopodia. Peculiar to the Radiolaria is a capsule in the centre of the contractilo body, and the appearance, both in this capsule and throughout the body, of many distinctly cellular elements. Many Radiolaria possess a peculiar slieleton of a needle-liko spicula of flint, and, more rarely, of an organic horny substance, similar in consistency to spongre."

Upon these grounds, then, this distinguished histologist has placed the Radiolaria above the Foraminifera in the seale of living things.

Ani what, then, are theso Radiolaria? I will answer this question by quoting a passage from the able review of Kiblliker's work in the (Luarterly . Jourmel of Science, vol. ii. p. 5:34:-

"And what exquisito forms do these Radiolaria exhibit! we feel 
sure that their beautiful shapes have only to be seen by our microscopists to make them forget Diatoms and Desmidiæ in their anxiety

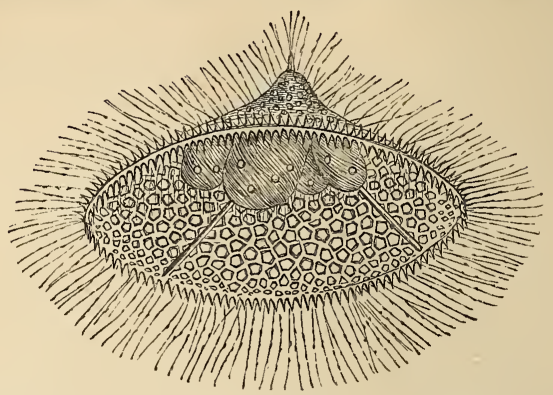

Fig. 74.-Euceryphalus Schultzei (magnified 150 diam.).-The whole animal living. The central capsule with the middle of the concave side of the silicious shell shown, deeply cleft in four unequal parts containing very small yellow cells.

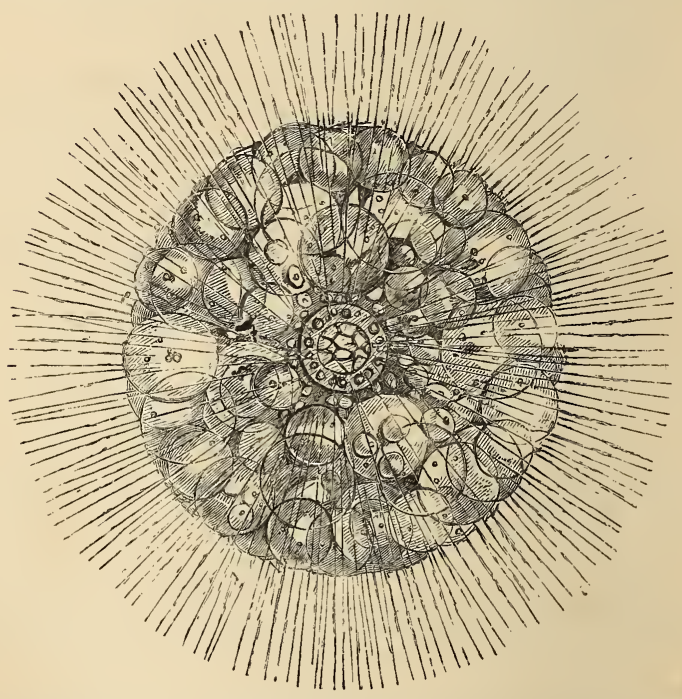

Fig. 75.-Thalassicolla pelagica (magnified 15 diam.).-The animal alive. The outer part consisting of numerous cells containing yellow bodies. The central capsule has oil globules round the margin, and a dark proto-plasmatic inner vesicle.

to possess them; for, along with the beautiful cases of these, they combine all the attractions of living and moving beings, and their interest is by no means confined to their external coverings. 
Some of them represent globular groups of pearls, with a brilliant central gem of more solid consistency, the whole emitting bright rays (pseudopodia) in every direction ; and, on examining the constituent globules, each one is found to be more or less highly organised (Fig. 75). Others are still more beautiful and interesting. One, for example, resembles a conical Japanese hat of honeycombed silex, bristling all round the rim and on the apex with spikes and harbouring in the crown of the silicious fabric the multicellular animalcule, from which numerous rays are projected (Fig. 74). Another is a perfect hollow silicious sphere of filagree, also honeycombed, and in the centre floats a beautiful sun, whose rays penetrate the

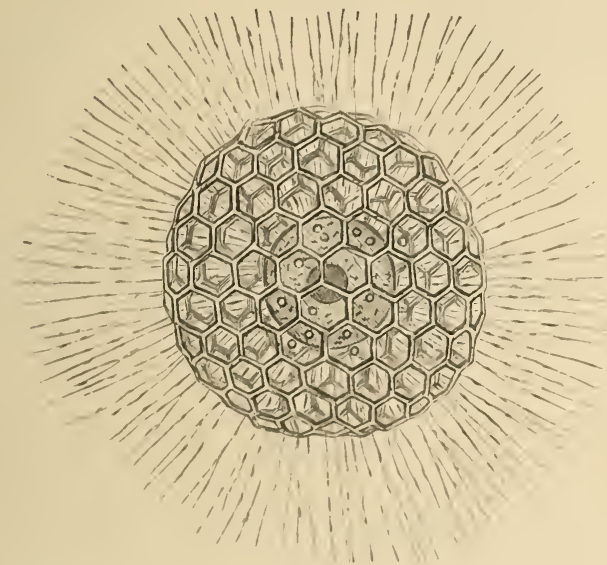

Fig. 7f,- Heliosyhara inermis (magnifled 300 (linm.).-The whole animal alive. The central enpsule is sen to eontuin 1 vesicles one-thirel its size, through the "boneycomb" of the shell. The fine psemilopulia cuanate from tho sarcolo of the central cupsuie.

open framework of the globular caso (Fig. 76 ); and a fourth-more exquisite, perhaps, than any of the preceding-might serve as one of tho insignia of some noble order, for it presents the appearance of a jewelled star. The eentral portion is the hyaline amimalcule resenbling a globular pearl in appearance, from which project silicious rays, some lance-shaped, some straight, and all meeting within the central globe (1'ig. 77. p. (i2). There aro many more such forms, varying in the shape of the central soft portions, or in that of the radiating silicious skinleton, or of the surrounding casework; hut all are more or less gracofinl aml clegant, and the delineations of firem in the present work have only to be seen to renter them eager objerts of seareh and fasourite subjects for investigation. 


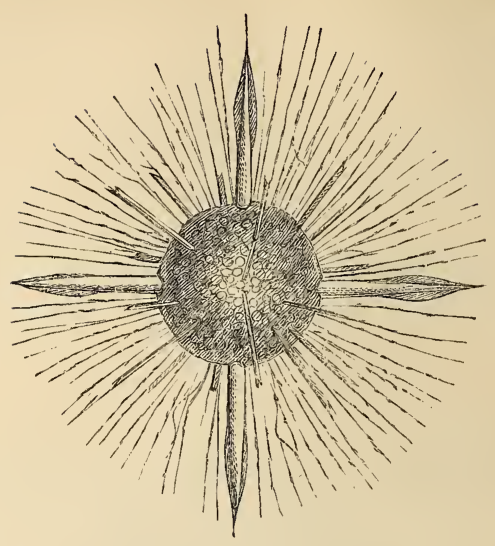

Fig. 77.-Acanthostaurus hastatus (magnified 300 diam.).-Whole animal living. Shell with twenty spines of different sizes. The central capsule from which these emanate is filled - with jellow cells. The pseudopodia radiate from the sarcode of the central capsule.

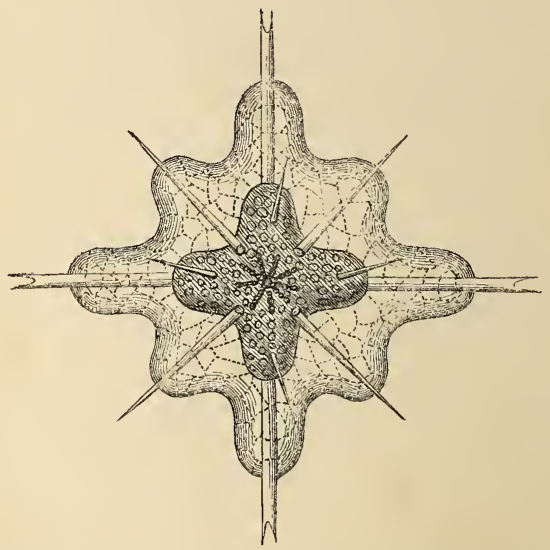

Fig. 78.-A. purpurascens (magnified 150 diam.)-Whole animal dead. The bi-convex fourlipped central capsule contains many yellow cells aud red pigment granules.

Let it be borne in mind that to the unaided eye these lovely forms exist only in the form of lumps of jelly, floating for miles on 
the surface of the sea. It is not until placed under the microscope that they present the appearance as shown in the figures.

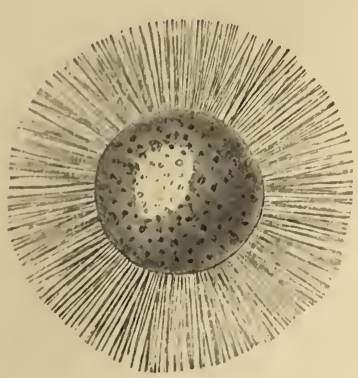

Fig. 79.

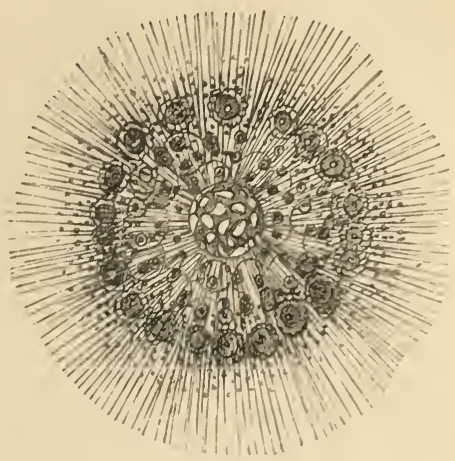

Fig. 80.

Fig. 79.-Physematium Mülleri (magnifled 15 diam.) - The whole animal dead.

Fig. 80. - Collosphoera IHuxleyi (magnifled 300 diam.) $-\Lambda$ whole colony alive. In the middle a large alveolus, surrounded by a sarcode net, within which are smaller alveoli. In the contral eapsule, which represents the parent animal, there are observed one or two balls of oil. The larger cells covered with a transparent shell, the smaller ones naked. Outsidcle the young brood, among the rays of the pseudopodia, a number of small yellow bodies, supposed to be gorms, are obscrved. (All after Kölliker.)

Kölliker divides the Radiolaria, as far as they are at present known, into thirteen genera and many distinct species, and their discovery, as I stated before, is quito of recent date. Their great beauty will, no doubt, make them a favourite subject of investigation with the histologist. They form a ready transition to the last -and, according to Kïlliker, tho highest-division of tho Protozon, which I now proceed briefly to notice, viz. :

\section{The Sponaes.}

I say, to notice briefly, because we have a recent classical and oxhaustive work upon the subject, to which naturalists can readily refer, viz., "The Monograph of the British Spongiado" by" Dr. Bowerbank, the first volume of which has been published by the Ray Society. Tho subject has also been illustrated by many papers in our popular publications.

But I do not wish for a moment to detract from the great scientific intorest which is attachod to the stucly of the Sponges. On the eontrary, I think there aro fow objects in natural history whose life is better worth recording than that of a Spongu. 
What, then, is a Sponge? "What I use in my bath every morning," answered an impertinent person who was looking over my shoulder when I was writing the question.

But this self-evident answer, like many other utterances, is only half true, for a Sponge is a great deal more than that when alive. Place the Sponge on the table before you and you will notice that it is covered with openings of various sizes, all leading to passages in the interior. Now, these passages, which tunnel the whole structure, are lined, when the Sponge is alive, with a more or less extensive layer of sarcode, which, as I have already explained, is the protoplasm which constitutes the bodies of all Protozoa, whether Gregarinid, Infusoria, Rhizopod, Radiolaria, or Sponge.

Now take your dead Sponge into your hand, and place it in water, and if you watch it carefully you will see the water enter in at the smaller pores till the Sponge is full. Now squeeze it, and you will notice that the water runs out of the larger openings, and, that when you have squeezed out all the water, the Sponge will suddenly dilate to its full size, showing that it possesses the power of contractility.

But the Sponge, when tenanted by its layer of sarcode, can do all that you have done with your hands. It can contract its skeleton, and force out the water from the large or efferent openings, just as you did when you squeezed it, and it can then relax the texture, allowing the fluid containing its food to enter in by the small or afferent openings.

A now venerable grey-headed philosopher, who has for forty years been silently working at University College (the well-known and respected Dr. Grant), was the first person who saw the living Sponge do what I have described; and well indeed can I share the delight which he must have felt when he first saw the magnificent sight. A lump of jelly contracting its skeleton as perfectly as the muscular finger of the highly-organised man! And small fountains of water pouring out of the large openings, containing, among effete and digested matter, ova, or eggs, or germs of future Sponges! Let us have his own description. It has been often quoted, but not once too often :-

"On moving the watch glass, so as to bring one of the apertures on the side of the Sponge fully into view, I beheld, for the first time, the splendid spectacle of this living fountain vomiting forth, from a circular cavity, an impetuous torrent of liquid matter, and hurling along in rapid succession opaque masses, which it strewed everywhere around. The beauty and novelty of such a scene in the animal kingdom long arrested my attention; but, after twenty-five minutes of constant observation, I was obliged to withdraw my eye 
from fatigue, without having seen the torrent for one instant change its direction, or diminish in the slightest degree the rapidity of its course."

I have said that in this efferent fountain the germs of the Sponge were emitted. Let us take up one of these tiny creatures and follow out its life history.

This germ, or gemmule, is essentially a Protozoon. It is a cell formed of sarcode. If you look attentively through a lens you will observe that the efferent fountain of water will propel this little germ to a considerable distance, where you would, $\dot{a}$ priori, imagine that it would be left to sink to the bottom. No such thing. You will find that, beyond the influence of the fountain of water, it has the power of motion, and, if you examine it attentively, you will find that this is due to a series of delicate cilia attached to the posterior part of the cell, just as we observed in the bell of Vorticella. This Sponge germ is an independent atom of living matter, and it moves through the water propelled by a will prescient of its future destiny among living things.

At length this little germ finds a resting place, which, when once found, is, like that of the Vorticella or the oyster, its locality for life. This is either a shell, a stone, a rock, or some solid substance in the water. When it touches such a substance it becomes attached to it by its ciliated extremity, and then flattens itself out into a thin disc, well shown in Fig. 81. Now it is seldom that very small
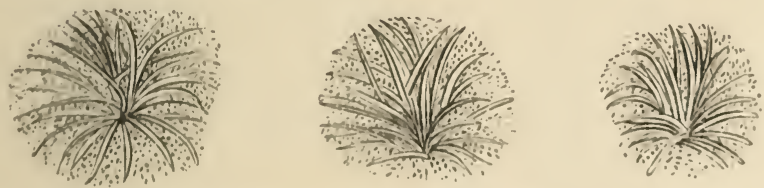

Fig. 81.-F'liren spongen gemumles flxod to a rock and apread out. The spieule are seen behig devoloped. There were three more on the roek from which Mr Bowerbauk's plate Wus takon, all of whlch would linve milted together, forming one Spongo.

spongers of the larger species are found, and this arises from the fact that a number of other germs fix themselves to the same foundation, and they then join together and grow up as one Sponge, as the figures in the ent would have done had they not been taken out of the water. Well, this delicate, thin, flattened-out film of sarcode would be a most agreeable bonne bouche for the numerous predatory inhabitants of the seil, and more particularly would it be liable to the insinuting attacks of small Amnelids. But, to compensate for this danger, the sponge is andowed with the power of forming a most remarkable series of flinty or challiy spicula, which, among 
other things, it uses as weapons of defence. Now, the first thing that the little Sponge does after it has become fixed to the rock, is to begin to manufacture these spiculæ, and it so arranges them that any animal coming full tilt to make a mouthful stands a fair chance of being impaled on their spear-like points. Should the assailant, worm-like, try to work its way through the outer defences, it finds a masked chevaux de frise all pointing outwards beneath the external covering of the Sponge. This matter of self-defence being provided for, that of growth comes next. Again the spiculæ are brought into play, to act as supports to the proper texture of the animal-that

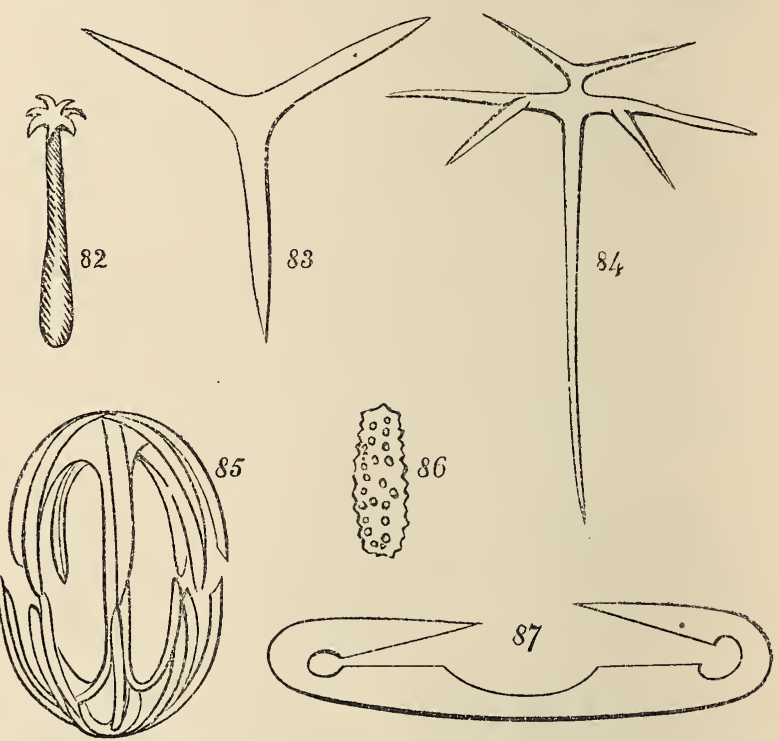

Figs. 82 (magnified 260 diam.) and 83 (magnified 160 diam.), sponge-spiculø of the skeleton. Fig. 84.-Connecting spiculum (magnified 90 diam.).

Fig. 85.-Defensive spiculum (magnified 308 diam.), from 2200 fathoms, Indian Ocean.

Fig. 86.-Tension spiculum (magnified 660 diam).

Fig. 87.-Retentive spiculum (magnifled 400 diam.).

which we know as Sponge, which scientific chemists call "keratode," but which Grant very properly altered to "keratose," because, although Sponge may appear like horny elastic fibre, it is not chemically or structurally allied to horn; while, strange as it may appear, it differs but very little in chemical constitution from silk. Well, then, the spongy texture grows upwards, all its internal network and canals being lined with a reproduction of the sarcode cell which con- 
stituted the germ, while the small inferent openings, termed pores, and the large efferent openings, termed osculre, being established, the process of feeding, so essential to growth in all animals, goes on prosperously. The food entering by the pores is thoroughly digested, and those particles which are not nutritious are rejected through the osculo. This food appears to consist of particles of either animal or vegetable matter, or both. Bowerbank thinks that some of the internal defensive spiculas are used for the purpose of destroying any live creature which may be drawn among them. Other spiculio are used as organs of prehension-that is, of attaching the Sponge to the rock; others are used as special organs of defence to the sarcode and the ovarium containing the gemmules. These spiculic are many of them very beautiful microscopic forms ; in fact, Bowerbank figures and describes at least 240 different varieties.

Such is a simple statement of the life history of a Sponge. As it does not grow continuously, but is subject to periodical periods of development, I cannot give any real data about the time occupied in the growth of any of the large species in our shop windows. If, however, two or more Sponges of the same species come into contact, they will join housekeeping and become united into a single Sponge. Different species, however, decline any such intimate association.

It will have been noticed in my short description that, in some respects, the Sponges possess a higher degree of organisation than any of the animals before noticel. For instance, they can close the osculas and open them at their will. By closing them they stop the fountain, which when open flows from them. This shows the possession of a power bordering on that of muscular fibre; and this is one of the reasons why Kölliker plices them at the head of the Protozoa.

To my mind there is something marvellously interesting in the economy of the Sponge. How beautiful a provision is made for the tiny speck which floats by its cilia through the world of waters in seareh of the rock which is to be its home; how wonderful its system of spiculan, all of which it is able to form according to its wants, now for defence, now for prehension, now for attack. and always for support to the horny-like tibrous covering within which it is to livo; how marvellous the reproduction of its germs-and all this in an animal which, to the most searching cye of science. shows ni) more organisation than a layor of glue or jolly! But the will: - the power to open and shut the osenda capriciously, and to expel the water with great foren therefrom, just as it has oecasion to do so! All this is truly wonderful, and would be inexplicable did we 
not know that the same Power which, as Newton remarked, caused the apple to fall to the ground, is the author and director of all laws, whether they affect the physical or the animal world.

The Sponges are found fossil in the oldest rocks. They attain their maximum in the chalk. Most of our flints have a Sponge or its spiculæ as a nucleus, round which the silicious mattter has accumulated.

With this chapter my history of the Protozoa finishes. In my next I shall treat of beings a step higher in the scale of existence. 


\section{PAR'T III. \\ 'THE CELEN'TERA'T'}

\section{CIIAPTER I.}

\section{THF HYDROZOA.}

Cuvier included the Proto\%oa and the group now to be considered in the sub-kingdom Radiata, so called because the animals were formed upon a type which consisted of a centre and parts radiating therefrom. Agassiz, in his recent Graham lectures, has made the most of this by endeavouring to show that the great animal kingdorn was specially created under four types, of which the radiate, as formed by Cuvier, was the lowest. But then, to support his view, he has been obliged to take his best specimens of the radiate type from the Echinodermata, an order placed by all scientific writers of the present day in a much ligher position in the scale of being. The two things cannot be reconeiled. We must either group together animals having a similar external arrangement of organs, but with a totally different internal anatomy, or we must do that which has been done-viz., bring together great classes which have a similarity of organisation, and place them in the scale ats they rise one above the other in the links of a great chain, each larger than that which precerles it. It is a farourite argument that such a chain does not exist in nature. This is, literally speaking. true; but the difliculty is at once got over by dividing the chain into six parts, each link in each part being of greater value than its predesessor, and the same with each chain when complete. Instead of four we thus make six great types of organised life, one of plants and live of animals. I have already consilered two, and I now proceed to point out the salient parts of the third. I propose, howerer, to sink altegether the term Raliata, and to aulopt for it that of Colenterata-a plan pursued by the best modem comparative anatomists. The name is at oned suggestive to the seholar of that all-important organ, the stomach (koilic, from koiles-hollow); and it owes its origin to the fact that in the group of animals to which it belonge it stomath is for the lirst time differentiaterl, ats it is alled in scientilie lamgruage. 
Hitherto we have found the food carried either into the general cavity of the body, or into vacuoles interspersed through its substance. In the Cœlenterata, however, the body substance consists of two layers-one an outside or integumentary organ, or skin, called the ectoderm; the other lining a cavity which is always present, and which, communicating with the mouth by means of a gullet, constitutes the stomach. This inner layer of body substance is called the endoderm. Now these two layers consist of vesicular bodies embodied in a matrix, the inner one having the cells applied to each other more closely, and increasing from without inwards, while in the outer layer they are more loosely scattered through the body substance or matrix, and increase from within outwards. If the reader will bear these simple facts in mind he will have a knowledge of the great difference which exists between this sub-kingdom and the last. By these two layers most complicated organs are developed. They produce deadly thread or poison cells, which have the power of benumbing their prey; they produce reproductive organs, colouring or pigment bodies, and granular matters, which are intimately connected with the great function of secretion; they can also protect themselves outwardly by organs of great beauty, or develop a skeleton to support them, as in the great group of calcareous, curiously and elegantly built-up bodies known as Corals. It is, in fact, upon the history in space and time of these structures that I shall principally dwell in illustrating the Cœlenterata. But I will take a general view of the whole family, as its members are rather celebrated for qualities which excite our interest and curiosity.

The Cœlenterata are divisible by anatomical differences as to the connection of the two layers with each other into two classes-viz., (1) the Hydrozoa and (2) the Actinozoa.

\section{The HydrozoA.}

The type of this class may be found in any stagnant ditch. It is known by the name of Hydra, or fresh-water polyp. It seldom exceeds, without its long tentacles, three-quarters of 'an inch in length. Its body is gelatinous, but endowed with great powers of contractility, and its stomach is capacious. From the ectoderm, or outer skin, it has the power of projecting vast numbers of thread-like organs, with which it benumbs or kills its prey. These are especially placed along the outer covering of the long tentacles by which the prey is caught (Figs. 88-92), and are projected by a beautiful mechanism presently to be described. These tentacles spring from a margin immediately below the opening which serves as a mouth ( $a$, Fig. 88), and are spread out as 
seen in the figure when the creature is hungry. Should any small worm or animalcule come into contact with the tentacles as shown in Fig. 92, it is immediately benumbed by the thread-like organs before alluded to, which pierce the body of the victim. When seen through the microscope the tentacles are found to be studded with nodular protuberances, as shown in Fig. 94 (p. 72). If one of these nodules is more closely examined it has the form shown in Fig. 95

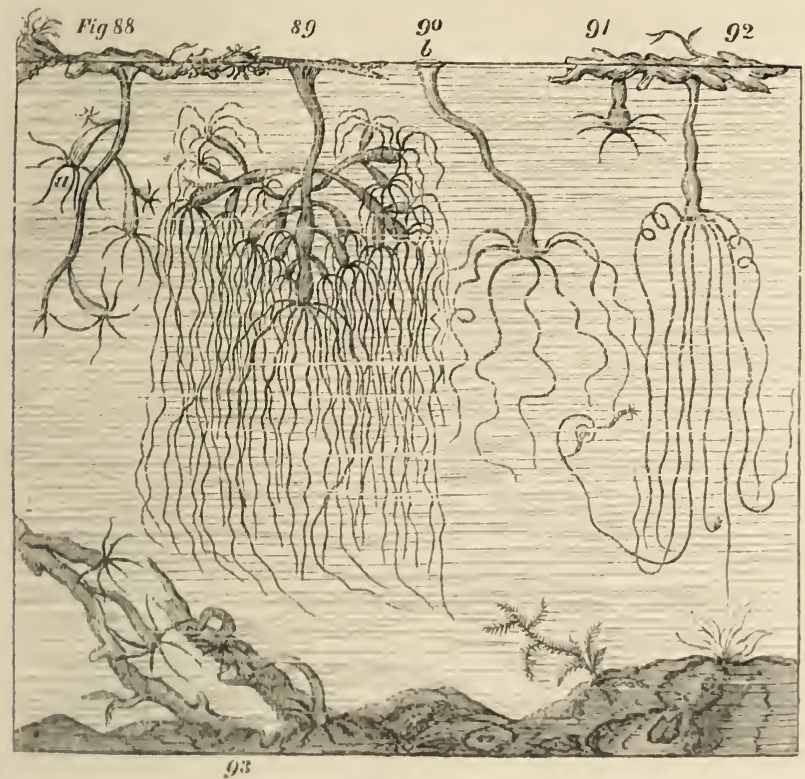

lig. 8.8- The common Ifylda virilis, or short-armed IIyclra, with young bulling from the purcut body.

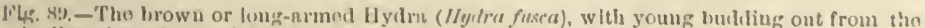

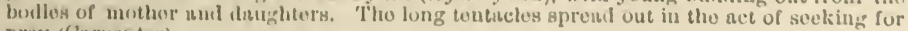
proy (Carpentor).

Fig. 90.-Hyilra floathig through tho wntor; $b$, its sucker extreunity, which, having become ilry, sorven us u Ilout.

Flg. 91. - Tho name digasting.

Fig. 9:- -llyilra fusct, with a small worm and mulmulculo just cumght in tho wutucles.

likg. 9:3,- Ilydras "progrosulng."

(1. 72); and if the threal-celi is treated with acetic acil it immediately shoots out, with the action of a spring, a long sharp-pointed threail. as seen in Fig. 96 (p. 72). By this means the proy is slain, and it is then drawn up to the mouth by the tentacles. and gradually 
swallowed; after which the creature takes its post-prandial nap, assuming the form of Fig. 91 (p. 71).

The Hydra has no legs, but it can move from place to place notwithstanding, for it is reasonable to expect that its hunting country will require changing. In order to "progress" it assumes the form shown in Fig. 93 (p. 71). But he is also one of the most cunning of rascals, for, well knowing that he must have a bad name, he adopts the following method of moving about, and, at the same time, of coming unawares upon his victim. He allows the sucker end of his
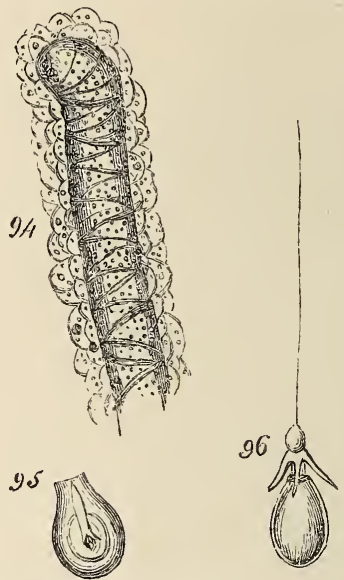

Fig. 94.-Tentacle of Hydra magnified 140 diameters.

Fig. 95.--"Thread cell," containing stinging organs, magnifled 450 diameters.

Fig. 96.-The same, with the spines and flaments protruded, magnifled 450 diameters.

body (b, Fig. 90, p. 71$)$ to become dry, in which condition it acts as a float, and thus he moves about the water with the currents, aided by any rowing power which his tentacles may possess.

One of the modes by which this singular creature increases is shown at Figs. 88 and 89 (p. 71), in which young ones are seen growing like the buds of a tree. In Fig. 89 a third generation is seen springing from the bodies of the second, and throwing out their feelers in search of food, just like their mother and grandmother, to whom they still retain an " attachment." Their tentacles never catch each other, but close instantly upon any unfortunate animalcule which ventures into such a dangerous country. Carpenter tells us that it is not unusual to see the parent and its young each get hold of the opposite end of some small worm, and commence a pulling fight for mastery. Strength, I presume, succeeds in the 
end. After a time the youngster separates from its respeeted parent and starts a hydra life of its own. They also increase by fissiperation or division, as we have seen done by the Infusoria, and also by the union of the sexes.

Trembley, by whom the true nature of the fresh-water Hydra was first determined, performed many most interesting experiments with them, which have been fully verified by later inquirers. Among other things, he tells us that upon one occasion two Hydræ had seized upon the same worm, and, after a short struggle, the strongest being unable to get the worm away, swallowed it with its brother polyp at the same time. But he was no nearer the winner of the battle by this manœurre, for digestion having gone on equally in the stomachs of the two Hydro, the swallowed one was ejected, none the worse for its adventure in the belly of the polyp. On another occasion he turned a Hydra inside out by means of a fine wire; thus the stomach was outside. But this proeess did not at all inconvenience the creature, which went on catching animalculæ and digesting them with what had been his outer skin, just as though nothing had happened.

To vary his experiment he cut one into two parts, and was surprised to find that in a short time eaeh developed itself into a perfeet polyp. He then eut off a small pieee with the same result, and even divided one into fifty parts, with the effeet of causing fifty new Hydræo to rise up. He then grafted one upon another, and even two of different species, and they grew firmly united, like the Sianese twins. It is remarked that when a Hydra is cut into two that the head portion develops a tail part more quickly than the tail part will form a head and tentaeles.

The history of the fresh-water polyp, or Hydra. is a very important and interesting one in science. The celebrated Réaumer was a firm believer in the floral or vegetative eharacter of Corals, Madrepores, \&e.; and when Peysonnel, a French naval surgeon, addressed in memoir to the Freneh Acadeny in 1727. maintaining their animal nature, he was strongly opposed by Réanmer. Peysonnel, heing quite sure that he was right, published, in 1751, a paper in the "Philosophical Transactions" of our Royal Society, and Trembley"s discovery of the Hydra came most opportunely to the assistanee of truth. The French Acatemy appointed a commission of inquirs. which eonfirmed all Peysonnel's statements. Réammer was convinecil. retracted his former opinions, and wrote in farour of the new doctrine. Strange to saly, howerer, the scientific world was not convinemd. Dr. Parsons analyosed and rombated Porsonnel's viows in a paper real before the lioyal Society in Maty 17.2., amel he seems to have auriod the majority with him. Abont this tiuse 


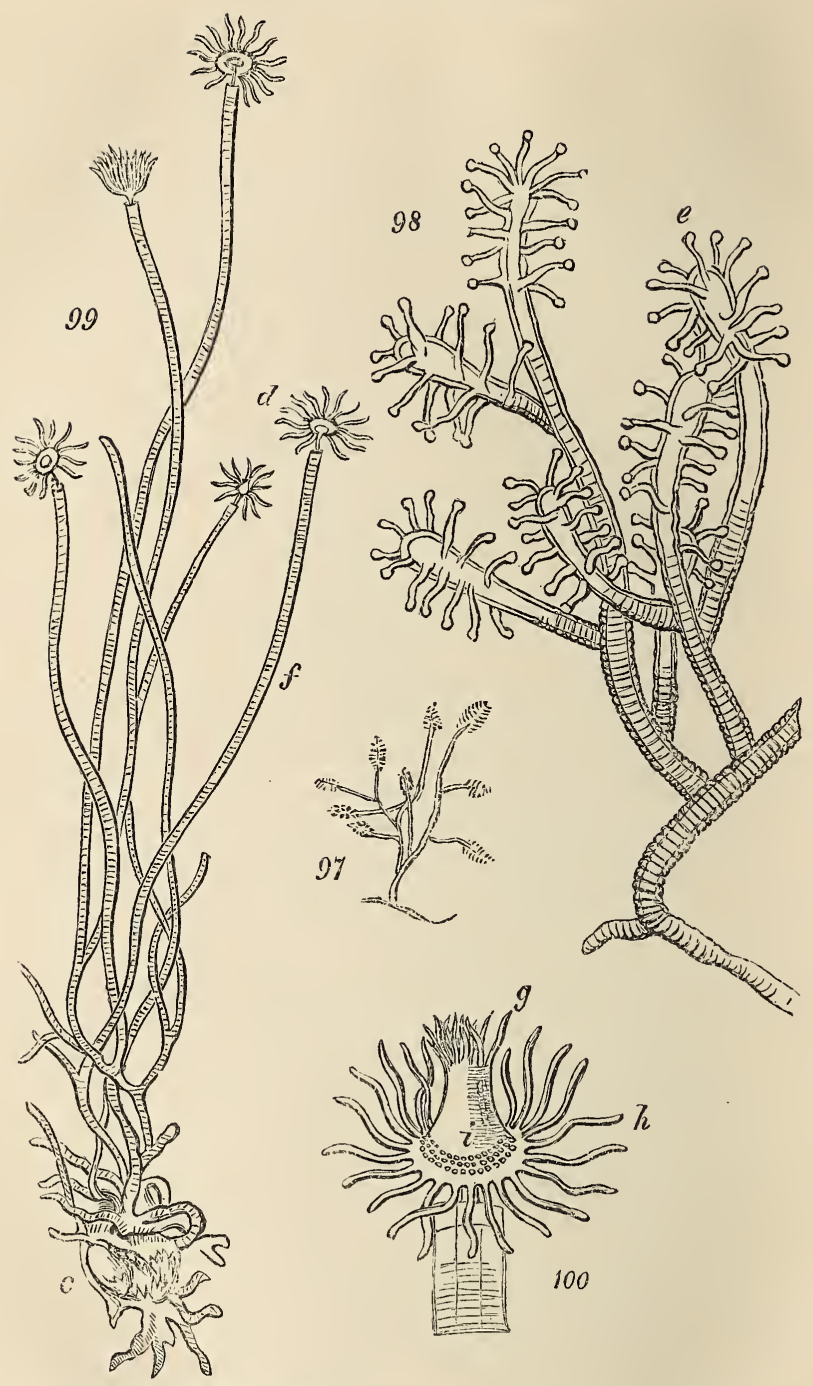

Fig. 97.-Hermia glandulosa; natural size.

Fig. 98.-Portion of the same magnifled; $e$, glandular-looking tentacles.

Fig. 99.-Tubularia indivisa, natural size; $c$, root; $d$, head; $f$, coenosare enclosed in horny polypidom. The cross lines shown in the stalks are not seen when the animal is dead. Fig. 100. - Head of T. indivisa magnified, showing the tentacles round the mouth $(g)$; those round the neck $(h)$; and a row of germs (i) round the base of the head (after Johnston). 
however, the matter was taken up by a thoughtful member of the Royal Society - a merchant in London-whose name, John Ellis, is bound up with the establishment of a great scientific truth. Ellis took up the study of Zoophytes for his amusement, and examined them minutely with the microscope. The result was the complete corroboration of Peysonnel's views, and the overthrow of the belief in the vegetable character of Zoophytes. His celebrated workentitled " $\Lambda$ n Essay towards a Natural History of the Corallines and other Marine Productions of the like kind, commonly found on the Coasts of Great Britain and Ireland "-was published in 1755 , and in 1768 the Royal Society awarded to him the Copley Medal, as the highest reward they could offer for what they termed, "the great accession which natural knowledge has received from your most accurate and ingenious investigation." Linnæus was at this time in the height of his great reputation, and he entered at once into the spirit of Ellis's discovery. Curious, enough, however, he confined his belief to those forms which built up their skeletons with lime-such as Coral-while he still maintained that the '/oophytes which lived in a horny polypidom, as it is termed, were flowers. The whole discussion is most interesting, and will repay perusal. Since that day the study of these forms has left little to be discorered, and, as I shall show presently, the animals which constitute the formerly called flowers of Zoophytes are nothing more nor less than close relations to tho Hydra, of which, as I have shown, the type lives in fresh water.

The description and figure of this creature which I lave giren will forcibly remind the reader of the many-armed monster, the Pienvre, which is described with such horrid and disgusting detail by Victor Hugo, in his new work, "The T'oiler's of the Sen." This creature, the octopus or poulp, is called by the ancients a polypus; and it was the miniature likeness of our little Hyelra to the octopus, which irduced licimmer to give the name of polypi to the family. Tho term Ilydra is derired from that of the monster which was said to exist in the form of a seil-serpent, the heal of which, ats the fable runs, wats reproduced as often as it was ent off; and it is a very curious eomeilence that we should have discovered in modern ditys a ereature whose head or tail will he reproduced when ont off, just an that in the fable was siall to have becu. It is also a most interesting fact that the little polyp, just three-quarters of an inch long, should be. to some extent. externally at least, a coumterpat of the octopus described by Victor Hugn as destroying human beings by antwining their long spinous arms about them. It is not. however, rertitin that the latgest spocimen of octopms has metually billend a human being : at least. I am not aware of suoh an 
instance, although there is no doubt that legs and arms have actually been seized by these creatures.

We shall best study the Hydra by looking at what we may term its morphology, or the different forms which it assumes in what are called Zoophytes, or plant-like animals. The word zoophyte is now limited to that class of animals of which the Hydra is the type, termed Polypifera, the compound skeletons of which have a plantlike form. The term coralline, often popularly applied to this group, is restricted to a small class which the botanists lay claim to, and which are at once distinguished from the Zoophytes by the absence of all traces of cells on their surface-a fact which the seaside rambler, armed with a pocket lens, will verify for himseif at any time.

Suppose, then, the said rambler finds, between tide marks attached to a sea-weed, a form like the small central figure (97, p. 74), he will at once by the above test know that he has a Zoophyte; and if he place it in a small glass of sea-water, and watch it with a lens, he will observe at the end of each tube a fleshy-looking body, which gradually protrudes its tentacles. This is one of the Corynidæ, or club-shaped Zoophytes. It is the simplest form which the hydraform animal assumes among the covered species. The tentacles, it will be observed, spring from all parts of the polyp's body, and although they can be drawn in and extended at pleasure, the body cannot be withdrawn into the tube. The tentacles are very short, and some of them being at a considerable distance from the creature's mouth, the latter bends its purposely provided mobile neck and meets the food which these distal tentacles may get hold of half way.

That part of the tube which is attached to the stone or sea-weed is termed the root, and in this genus is closed. The branching tubes, however, are all hollow, and are filled with a continuation of the same substance as that which constitutes the body of the polyp (Figs. 98, 99, p. 74), thus forming a compound animal, it may be, of a hundred or a thousand brilliantly-coloured scarlet, or red, or rose polyps, all connected with each other, and yet to a certain extent independent organisms.

The reader will be somewhat reminded of the Rhizopoda before described and figured; but he will remember that when the Lieberkühnia, or Gromia, caught any prey in their pseudopodia it was digested there and then, and the nutriment was conveyed into the general, though imperfect and irregular, circulation. In the Hydra and its congeners, however, the prey is brought by the tentacles to the mouth, and is swallowed and digested in a regularly formed stomach. Hence the great biological difference between the two forms. The animal inhabiting the Corynid as well as the other 
Zoophytes is in every respect similar to the Hydra; in fact, were we to imagine the young buds sprouting and re-sprouting from each other, as shown in Fig. 89 (p. 71), not to be cast off and become independent individuals, but to be covered with a horny or calcareous case, it would represent one of the trec-like branching Zoophytes.

We are now prepared to see the real simplicity of the principles upon which animals are classified, and I must warn those who wish to gain any knowledge of zoology not to neglect this most important part of the subject because it may appear dry; on the contrary, it is the very pith and marrow of the whole subject.

The Coclenterata, as I have said, are divided into two classesthe Hydrozoa, which we are now considering, which have stomachs hollowed out, as it were, in the substance of the animal; and Actinozoa, in which the stomach is more or less separated or free. The Hydræ, which have formed the subject of this chapter, in their naked form, constitute the first family, into which Hydrozoa are divided, and are termed Hydridæ, which is represented by a single genus Hydra, and four or five species. Well, the whole family of the IIydridæo, being very much alike, I have not thought it necessary to draw attention to its divisions. The second family, the Corynida, are those I am now treating of, and the genera differ from each other in several particulars; but all agree in the fact that the polyp cinnot withdraw its club-shaped body within the tube which supports it. The specimen figured belongs to a genus erected by Johnston, called Hermia, and the name was taken from the lines in Shakespeare -

What wicked and dissembling glass of mino

Made mo comparo with Herwials sphery eyne.

Tho glaudular-looking bodies at the end of the tentacles (Fig. 98, p. 74) are as the guardians of the creature, the supposed "sphery eyno" which induced Johnston to characterise his new genus under the name Hermia-a fanciful name enough; but then it must be remembered that all classification is more or less artificial.

'There are several generi of Corynidas. The most extensive is that of Tululari, and perhaps the best known example is that of Tubularin indivisu, so called because each tube remains single, and does not branch off like many of the others. The animal which protrudes from the extremity of the tube is of a beautiful scarlet colour, and the head (Fig. 100, p. 71) is crested with two rows of tentacula. Sereral of these tubes rise from the same part of the stome, or shell. upon which the root is fixed, as shown in the figure (!)! c, p. .7). Eillis compared the tubes to straws without joints. They are filled with a redilish pink soft substanes, which is commeted with the heal. 
The neck is very narrow; and when the animal becomes weak in the aquarium the head readily drops off. In scientific language the head (Fig. 99, $d$, p. 74) is called a polypite, while that in the tubes is denominated a cœnosarc (koinos, common-sarx, flesh) (Fig. 99, f, p. 74); the two together are called hydrosoma (hydra and soma, body), and the point of attachment or root hydrorhiza (hydra and rhiza, root), while the polyp cells which are absent in Corynidæ-viz., the small cups in which the polypite lives, are called hydrothecoe (hydra and theca, covering).

These names are all expressive and simple enough. Then the horny or calcareous skeleton was called by Kirby a polypary; others, Johnston among them, have used the term polypidom to express the same thing; and the cavity which exists in the body of the polyp, and which extends through the conosarc, is called the somatic cavity. A little attention to the terminology and the student will be able to pursue his sea-side investigations very easily.

\section{CHAPTER II.}

\section{The Hrdrozoa (continued).}

The Sertularida (sertulum, a garland of flowers; terminal, ides) form the third group into which the Hydrozoa are divided. They are at once distinguished from the Corynidæ by the bell-like expansions-called, it will be remembered, hydrothecæ-which crowd all the branches of the Zoophyte. Into these bells the expanded head of the polyp can retract, thus distinguishing them from the Corynidæ, which have not that power. The family is divided into many different genera, and forms by far the most numerous of any of the divisions of Hydrozoa. Fig. 101 represents one of the common species, and may be taken to illustrate the typical parts of the Zoophyte. To show this clearly, I have at Fig. 102 given a representation of the upper part magnified. The head of the polyp, with all its tentacles spread out in search of food, is seen at $a$, and at $b$ it is shown contracted and withdrawn into the hydrotheca $(c)$. Then observe the cœnosarc $(d)$ passing along from the head $(a)$, covered with a bead-like tube, which, it will be remembered, is part of what is called the polypidom.

Observe how this conosarc joins with the other branches, and at $e$ constitutes the centre of the stem of the Zoophyte, just like the pith of a tree. 
If you will look at Fig. 101 you will observe that lower down such a stem is attached to a piece of rock. Then remember that this cenosare in its totality, and the stomach and heads in the hydrotheco, termed polypites in their totality, constitute the com-

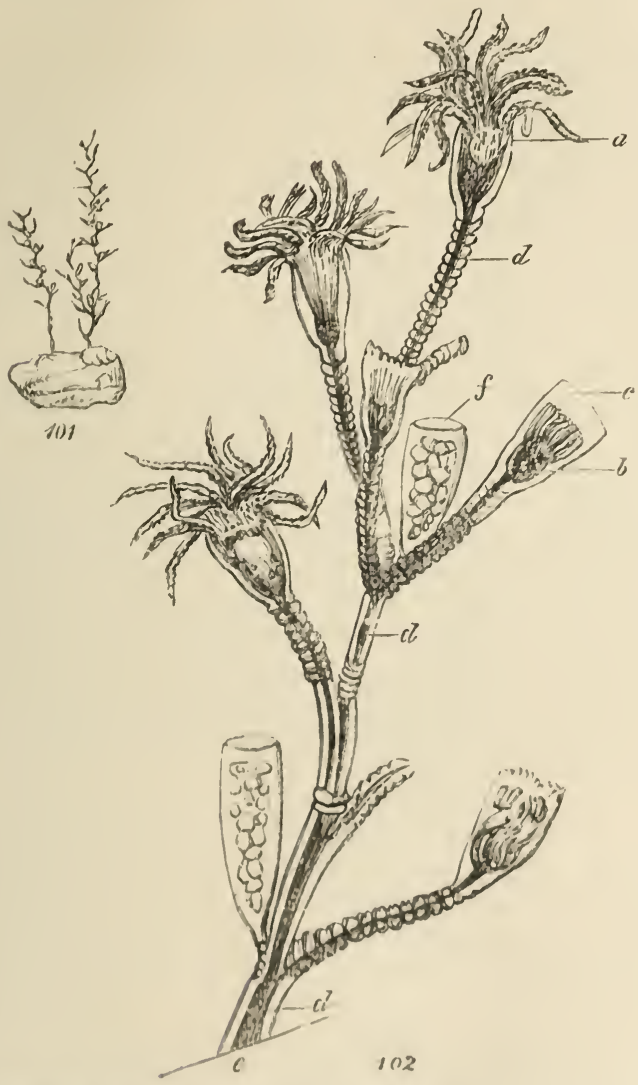

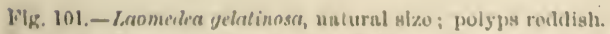

Fig. 102.-Part of the ramo magnifled; an polype with tentucles expanded in searoh of foorl:

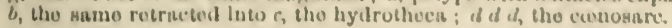

pound animal called, with its extermal covering, a Zoophyte. And further, let me repeat, that this componnd animal is formed of an ontor skin, called an coloderm, and an inner skin, called an cmedederm. and that the centre is hollow throughout, constituting what is 
termed the somatic cavity: and you will understand ever more all about the formation and terminology of Zoophytes, the Sertularidæ being typical of the family. I have said nothing about the bell ( $f$, Fig. 102, p. 79) containing the rounded-looking bodies, because these are connected with the creature's propagation, and the whole interesting subject of development will be best considered after the different families have been illustrated and described.

Well, now, as I have said before, these Sertularidæ are very beautiful objects, and, as most people go to the sea-side, I hope I shall be the means of adding to their pleasure by pointing out how they can be recognised and studied. They are found upon anything which will give them a firm attachmentshells, pebbles, rocks, pieces of wood-and are even parasitical on sea-weed; and the heads and tentacles are of various colours, looking, as their name implies, like garlands or bouquets of flowers. Every one at the sea-side who cares about studying natural objects should carry with him a good pocket or Stanhope lens, which he can buy from an optician for a few shillings, and if he places his Zoophyte in a shallow vessel, and covers it entirely with seawater, he will be able to watch its movements and examine its beautiful structure with the greatest ease. I have appended some magnified figures of each known genus of the British Sertularidæ, and upon these I will offer a few general remarks.

As seen by the naked eye the Sertularidæ have little to invite attention, many of them being passed over as minute sea-weeds, or lumps of moss, or something not at all worth looking at by those who are attracted by the more gorgeous visible beauties of the seaanemone, or the Coral, or

Pale glistering pearls and rainbow-coloured shells.

Still there are many of them which have a characteristic form, which attracts the eye of the collector at once. Thus, Fig. 103 is exactly like a miniature tree, with the branches springing from the bottom of the main trunk, and occurring in the same order and regularity as in the tree.

Observe also that the same rule of alternation obtains in the branches as is observed in the plant. The thick-looking stem from which the branchlets proceed in the figure is one of these branches magnified. The main stem in a state of nature is in fine specimens more than half the thickness of that in the figure. It is only when magnified that the minute terminal branches show the cells and polyps as seen in the figure. The latter are yellowish in colour. The branches all come off at an acute angle from the stem, which gives them the appearance of the backbone of a fish, and hence it is 


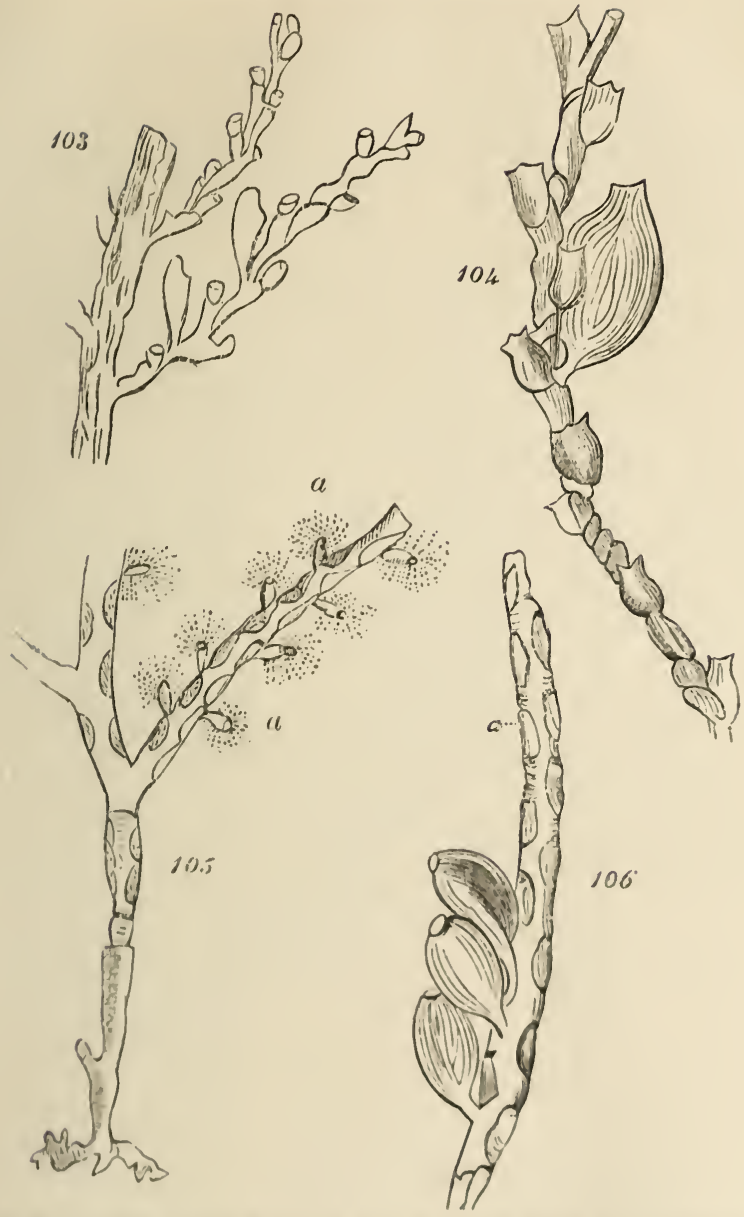

Fig. 10:3.-Thna halecina (nagulled); common on sholls and stones in denp water; herriughoun corallius; polypa yellow.

Flk. 101. - Nertularia polyzonim (magnlfled); on sholls and other Zoephyteg in deep water polypm whlte, nomelimen brlght yellow.

Flg. 108,-Thuinara thuin (yumug), magnlflud; on alolls in deepl water.

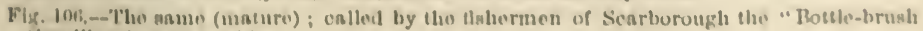
('orulline;" polypes whilo.

called the "Herring-bone Coralline." It is found on shells and rocks, below the low-water tide mark. There are two other species 
at least in which the hydrothecæ may be more easily distinguished by the naked eye. In one of these, $T$. muricata, the cells are covered with spinous ridges. The other is a rare species, called after Mr. Bean, of Scarborough, its discoverer.

Figure 104 (p. 81) is an example of the larger genus, Sertularia. It was called the "Great Tooth Coralline" by Ellis, and looks, in its

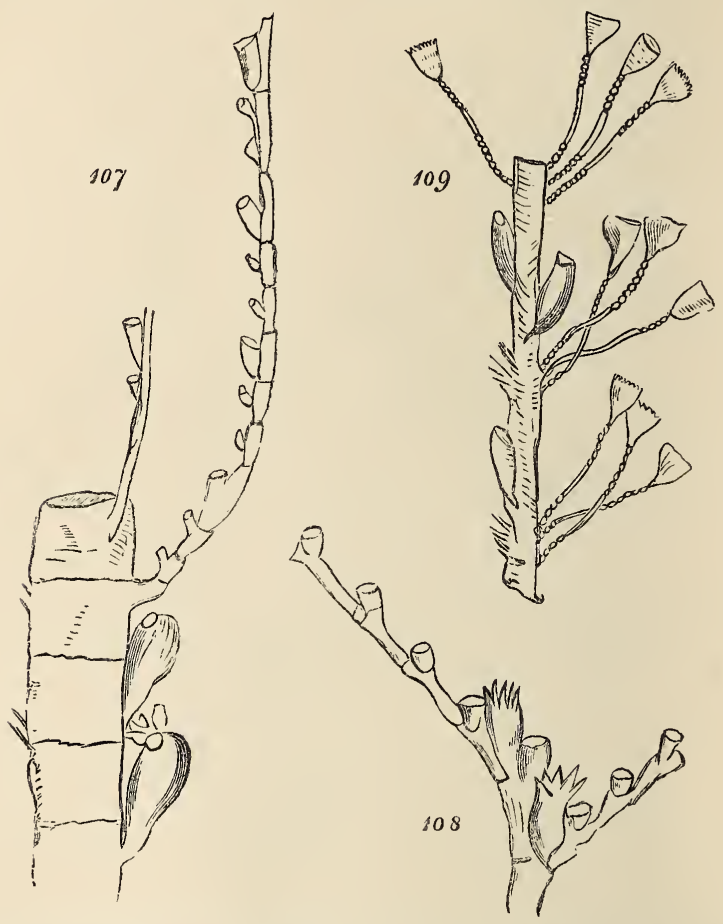

Fig. 107.-Antennularia antennina (magnified); common on shells and rocks in deep water; polyps yellowish white.

Fig. 108.-Plumularia pinnata (magnified); on shells and stones in deep water; polyps reddish.

Fig. 109.-Campanularia verticillata (magnified); on shells: "Horsetail Coralline."

natural condition, when attached to a fucus or shell, like long threads of small "glistering pearls." One of the species, S. argentea, when mature is a very striking object. The stem is regularly divided, like that of a plant, by nodes, from each of which springs a whorl of branches in which the polyp cells are fixed. It attains the length 
of eighteen or even thirty-six inches, in which state it looks like the tail of a squirrel, and has hence obtained the name of "Squirreltailed Coralline." Johnston, in hís "British Zoophytes," describes sixty-eight species and varieties of the Sertularia, and figures fifteen or sixteen of them. Figures 105 and 106 (p. 81) are the young and mature species, which I have selected to illustrate the genus Thuiaria, so called from the Greek word for cedar, Thuia, and the terminal aria. In its mature state the branches fall off the lower part of the stem, giving it the appearance of a "Bottle Brush," which is its popular name among the fishermen of Scarborough. It reaches to a height of twelve inches. The hydrothecæ or polyp cells are seen at $a$, arranged alternately on each side of the magnified branchlet. There are only two species of Thuiaria.

Figure 107 illustrates the genus Antennularia, of which there is one species. In their natural state they are seen springing from a clustered root, and rising up single or irregularly branched to a height of ten or twelvo inches. When dried the unbranched specimens look like the antennæo of a lobster; hence the scientific (Antennularia) and popular names ("Lobster's Horn," or "Sea-Bend") given to it by Ellis. The colour is yellowish horn.

Figure 108 illustrates a very beautiful genus-that of Plumularia, so called from their graceful feathered forms-of which Johnston figures eight species. The one figured is called by Ellis the "SeaBristle," and springs from some shale or stone like a bristle fastened on the upper half, with branches carrying the hydrotheco, as shown in the figures. It is thus described by the Rev. D. Landsborough, in his "Excursions to the Isle of Arran:"

"There was something in the scollop shell more conspicuous: . it was like a drookit white feather. But place it again in the water, and what does it become? It has recovered from its state of collapse, and though still like a feather it is one of great beauty and elegance; it is a Zoophyte, Plumuluria pinnata. You would not think that that beautiful white feather had life; but you see only the habitations. The alarmed inhabitants have fled into their houses (hydrothecro-C. R. B.) But plince the polypidom, as it is called, in a tumbler of sea-water, and when the alarm is over the inhabitants will again appear. The polyps are hydraform, and spreal forth many tentacula in search of food, which they greedily grasp. The feather is formed of calcareons matter, mixed with gelatine to give it flexibility, so that it may better stand the buffoting of the waves. Observe the stem or quill of the feather, and rou will see that it is full of red matter (the conosare-C. I. B.) Firery plumule of the feather is a street. Evon with the naked eyo you may observe in each plumule about a dozen notehes. Each of 


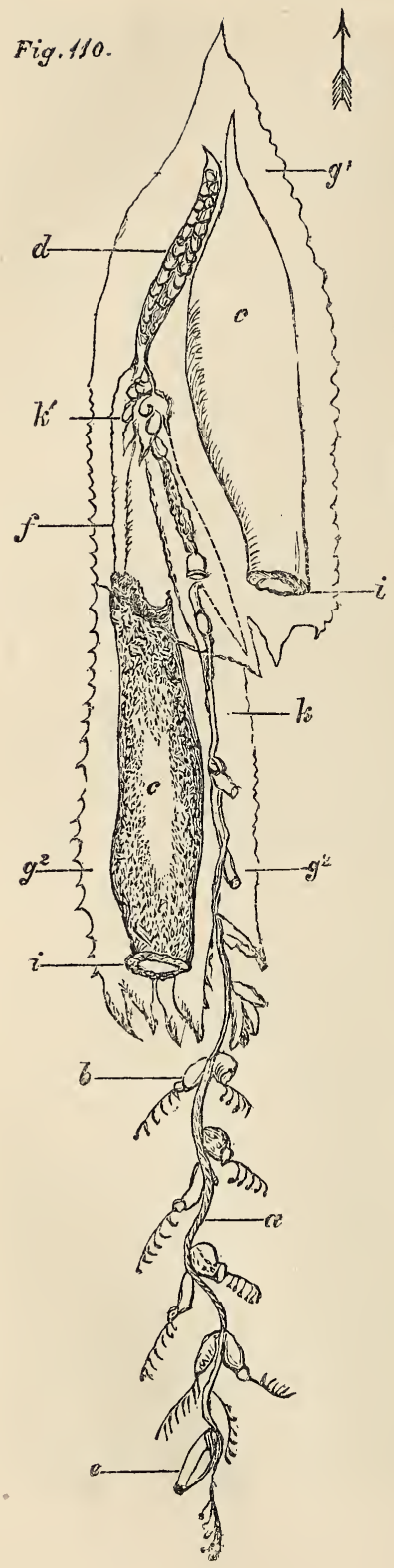

these is the house or cell of a polyp; so that in a good specimen we see a kind of marine village, which, under the teaching of God, has been beautifully constructed by the thousand inhabitants it contains."

The last genus in the British forms of the order Sertularidø is illustrated in Fig. 109 (p. 82). They are called Campanularia because the Hydrothecæ are bellshaped. Johnston figures three real, and figures one and describes two doubtful species-six in allas inhabiting our coasts. The species figured looks in a natural state like a small plant rising from a single stem, and branching off into the shape of a "horse's tail," which is the popular name given to it by Ellis.

\section{The CALYCOPHORID丑.}

The next phase in the morphology of the Hydrozoa is observed in a most interesting family of Zoophytes, found only far out at sea, and therefore termed oceanic. It will not be necessary for me to dwell long upon this or the next group, also oceanic-viz., Physophoridæ, inasmuch as specimens are not so accessible for examination to our sea-side ramblers. But they are very interesting and beautiful creatures notwithstanding. The

Fig. 110.-Diphyes dispar (magnified); $\alpha$, the cœenosarc; $b$, the polyp with its single tentacle; $e$, the same, covered with its hydrophyllum; $c$, nectosac, or locomotive organ; $d$, the somatocyst; $f$, duct leading from the hydræcium, which, joining with others, forms the connection of the swimming floats and the somatic cavity; $g^{\prime}$, the proximal nectocalyx, or "swimming float;" $g^{2}$, the distal nectocalyx; $i$, $i$, the mouth of the nectosac; $k$, the hydræcium; $k$, the hyslræ cial canal (after Huxley). 
Calycophoridx (cup-bearing Zoophytes), so called by reason of the "swimming-cup," or nectocalyx, to which the different parts of the animal are attached (Fig. 110, $g^{1}$ and $g^{2}$ ), are very singular-looking creatures, as may be seen by looking at Fig. 110, which represents the first member of the family ever discovered. They occur in various parts of the world, but especially in tropical seas. They are, however, abundant in the Mediterranean, and are sometimes found floating in the waters of our own coasts. I will endeavour to give the reader, by the assistance of the figure, a description of these Zoophytes, and here I shall call into requisition a knowledge of the terms given to the different parts of the compound animal.

Everybody is acquainted with the bright glistening "jelly fish" left on our shores by the receding tide, and many have reason to remember them on account of their stinging qualities. Now I have only mentioned these "jelly fish" in connection with our cupbearing zoophytes in order that we may have an idea of their bodily consistence and character. They have no other connection with them except the ties of family, which we shall see by and by. I may here state, however, in parenthesis, that they who desire to get a sound knowledge of zoology must ignore such terms as "jelly fish" or "shell fish." These animals are not fish in any sense of the word. I should not have thought it necessary to make this apparently trivial remark had I not found that even educated men will sometimes keep up a delusive nomenclature because it is popular.

Well, then, the Calycophoridoo are animals possessing a body having the consistence and appearance of the Meduss found on our sea-shores, but, as a general rule, the shape and appearance shown in Fig. 110. They consist in this family, the Dyphyde, of two similarly formed "swimming cups," or nectocalyces, as they are called by Professor Huxley, $g^{1}$ and $y^{3}$ fitting into each other.

In the centre of these swimming cups are noticed the two long open tubular-looking bodies termed nectosacs $(c)$. These are the orgaus of locomotion, and are formed of longitudinally-placed muscular fibres, by the contraction of which the water is expelled from the opening (i) in force, and, as a necessary consequence, the animal is propelled backwards in the direction of the arrow. It $d$ will be noticed a chamber filled with inclosed spaces termed racuoles, which give it a cellular appearance.

This is the proximal extremity of the conosare (a), which is not. as I before mentioned, covored with a horny case like the Sertularida. This chamber is callow by Huxley the somutocyst. and it will bo observed that it is eomected by at narrow neck with another dilaterd portion of the conossure, which is, in fact, a chamber from which proceed tho various ducts $(f)$ which connect the orgins of locomotim 
with the somatic cavity. The cœnosarc now proceeds between the two swimming bells, and through the distal one, whence it floats freely in the water. It bears naked polypites (b), each having a single tentacle, and also polypites covered with a leafylike organ, termed hydrophyllum by Huxley (e).

Such is the beautiful provision by which the unattached or free Zoophyte is enabled to float or swim through the water. The natural size of the specimen figured is shown by the line by the side of the figure. Nothing can exceed the delicate beauty of these creatures when seen first in their native seas. The coenosarc $(a)$, with its naked and covered series of polypites ( $b$ and $e$ ), sometimes reaches a length of several inches, and has fifty or sixty or more of these bodies attached to it. They can be drawn entirely within the chamber (k), which is therefore called the house of the Hydra, or, in scientific language, the hydræcium. So delicate is this cœnosarc that sometimes we are told it can only be seen by the play of the light, and the slightest touch will make it separate from the floats. Cuvier thought these floats were two distinct individual animals, and hence he gave them the name of Diphyes. Professor Huxley has divided the order Calycophoridæ into four families. The first three are separated from each other by differences in the hydræcia and hydrophylla, which I need not enter into. The fourth has many swimming bladders instead of two, and the hydræcium (k, Fig. 110, p. 84) is incomplete. Professor Huxley's history of the "Oceanic Hydrozoa," published by the Ray Society, is a model of scientific detail and elaborate and accurate illustration. Although we cannot go through the voyage of the Rattlesnake with the learned Professor, we can imagine the patient investigation and the real love of science with which, during that survey, he dealt with the various new links in the great chain which came under his notice. And we cannot be too grateful to the man by whose labours the means of studying the beautiful inhabitants of the wide sea are brought within the reach of our library table.

\section{CHAPTER III.}

\section{The Physophorider.}

THE Physophoridæ are, as their name expresses, "Bladder-bearing Zoophytes." The order is represented, but not typically, by the well-known singular creature called by sailors "the Portuguese manof-war" - the Physalia pelagica of scientific naturalists. An oblong bladder-like body about the size of a goose's egg, or larger, with a 
ridge-like back terminating in a point, which is movable at the will of the creature, with a fringe round the part in contact with the water, and a number of long blue tentacula, extending sometimes ten or twelve feet into the water; the beak end of the back a rich carmine, and the rest blue, while the sides and fringe are iridescent with yellow and green and blue, glittering in the warm tropical sun, and gilding this fairy of the sea with the rich colouring and harmonised tints which mark a thing of beauty. Such is the "Portuguese man-of-war," or "galley," or "frigate," which sometimes in countless thousands floats along at the mercy of the currents or the winds of the warm seas of the tropics.

Monsignor Virtue, R.C., Chaplain to the Forces, and now stationed in Colchester, informs me that this Zoophyte is very common on the shores of the islands of Bermuda, where, like the Medusæe on our own coast, it is thrown helpless by the receding tide. He says that he never saw there any of the yellow or green tints which are described and figured in the second volume of the Intellectual Observer, p. 233, by Mr. Noel Humphreys, from a British specimen; that the principal colourings are the amaranth crest, and the deep blue of the rest of the ridge and sides relieved by white. He also says that he never saw any specimen there having the number of tentacles figured by Mr. Inmphreys, and that the fullgrown size is considerably larger than a goose's egg, as stated by mo on the authority of Dutertre in his description of the Antilles.

Mr. Bennett, in his "Gatherings of a Naturalist in Australia," where he gives a most interesting account of the Physalia, states the size of a full-grown specimen to be 5in. long, and the tentacula from $4 \mathrm{ft}$. to 5ft., with the power of much greater extension. Mr. Himphreys does not give the dimensions of the specimens figured in the Intellectual Observer, nor does he say whether the figure, which is :37-10th in. by $1 \frac{1}{2}$ in., is the natural size or not-an omission much to be regretted. The discrepancy, however, in size and colour in the deseription of this Zoophyte arises not only from the fact that they differ in both accorling to ane, but that in the opinion of some naturalists they are livisible into several species. M. Eschscholtz describes threo species of Physalia :

1. P. Guruellu, which is sin. hy $2 \frac{1}{2} \mathrm{in}$. of bright purplish red colour, with dirk extremities and blue lines in the fold of the crest. Tentacles red, with dark purple acetubula; the smaller ones blue. IIab), Atlantic, from Azores to Brazil.

2. I. Pelatgice-2 $2 \frac{1}{2}$ in. long; when young, pale blue. In the alult both ends are grien, and the erest purple in its highest part: tentacles blue, with dark acetubula. Hab.. Atlantic, especially near Capo of Good Hope. 
3. P. Utriculus.-Length, $3 \frac{1}{2}$ in. ; colour of the crest and middle part of the bladder, greenish; the two extremities blue. Hab., tropical region of Pacific.

Professor Huxley, who follows Eschscholtz in this division, expresses doubts whether these species are distinct or not; and he feelingly exclaims that the study of the species-making efforts of Von Olfers, Lesson, and Lamarck had only one result-that of producing a somewhat unpleasant vertigo. Mr. Bennett has given us the best account of the Physalis, for he had opportunities of examining any number of them on the Australian coasts, whereon they were cast after storms. I will give a brief résumé of his description.

The bladder ( $a$, Fig. 111, p. 90) is about five inches long in adult specimens, and the dependent tentacula $(b)$ are several feet in length, but capable of being extended much farther to seize any victim which may be within reach thereof. The bladder is tough, slightly elastic, and semi-transparent. Its lower part is of a light blue colour, streaked or veined almost imperceptibly with delicate green pencillings, the crest and beak being of a rich carmine, changing in different lights to a brown, green, or purple. These colours soon fade when out of the water, except the tentacles, which retain their rich purple colour for a considerable time. Mr. Bennett says the creature has no power of guiding its blatder-like float, but is at the mercy of wind and tide, and that it cannot collapse or distend its bladder by the exclusion or admission of air. The long tentacles appear like a connected series of globules containing fluid, having a sucker at the free end, which they can fix tightly on their prey, benumbing it at the same time. This is not, however, done by the exudation of a glutinous substance, as described by Mr. Bennett, but by the agency of a vast number of thread cells, from 1-50th to 1-300th of an inch in diameter, which send out threads, as already described by the Hydra (Figs. 115 and 116, p. 91). The Physalis has the power with these threads of inflicting great pain on the human hand, round which they will entwine themselves if carelessly taken hold of, as M. Dutertre tells us he did in one instance to his cost, the pain produced causing him to call out most lustily. Mr. Bennett also, with true scientific zeal, purposely exposed himself to one of their unfriendly squeezes. He seized hold of the bladder, and immediately the creature lifted up its tentacles and wound them round his hand and fingers, giving him no little pain and some difficulty in getting rid of their embraces. He says the violent stinging continued so long as the smallest particle of tentacle remained attached to his hand. There were also constitutional disturbances afterwards, such as quick pulse, fever, impeded action of. 
the muscles of the chest, which were stiff, as in rheumatism, causing painful dyspnoea.

In the specimen of Physalis caught off the Isle of Wight there was a fish entangled in the tentacula; and Mr. Bennett had the opportunity of watching in his, taken under similar circumstances, the progress of absorption of the digesting fish. As it shows all the principal parts very well, I have figured the small variety called by Eschscholtz P. utriculus, and which is drawn from life, and very minutely described by Professor Huxley in his monograph of the "Occanic Hydrozoa." When the long tentacles $(b)$ have come in contact and seized and benumbed-say a small fish-they shorten themselves by assuming a corkscrew form, and the prey is then brought up to the polypites, which are seen with their open mouths at $c$, and which are crroneously called small tentacles by those who do not correctly follow the morphology of the Hydrozoa. The prey being brought within convenient distance, each polypite applies his sucker-like mouth, and the fcast bcgins. Mr. Bennett describes the passage of particles of the fish, as seen through the transparent tissues along the absorbents. In reality he saw them passing into the stomach of the polypites, just as he might witness the same process in the fresh-water Hydra.

Like the Calycophoridæ, many of the Physophoridæ have swimming cups ; but, in addition, thcy possess a remarkable organ called a pneumatophore, which is, in fact, a chamber filled with air, by which they float permanently in the water. Mark here the design shown in the formation of the last two orders of Zoophytes. The cup-bearers move voluntarily through the water, and are prorided with an apparatus for that purpose. The air-bag would be to them an incumbranec; but, as the bladder-bearer's have no such organs of locomotion, they are provided with an apparatus which, being filled with a fluid lighter than water, keeps them permanently afloat. Now, this pnematophore is generally placed at the proximal end or apex of the Physophorid ; and, as it camnot always be seen in drawings of the animals, I have given a diagram from Professor Green's excellent manual of the Corlenterata, which will illustrate the position of this organ in all the genera, and at the same time show how the order we are now lealing with differs from the last (Fig. 117, p. 91). This pmemnatophore is diagnostic of the P'hysophorida. In the "Man-of-war" it constitutes the greater part of the larger bladkerlike conosare (a, Fig. 111, p. 9) ). It contains within it another bag, callod by Huxley a pmeunatocyst, which has an opening communicating with the external air. There aro two series of tentaches, the long dependent (b), and the shorter ones (d). At the base of each tentacle there is a theshy earal bayg (c), which is covered externally: 


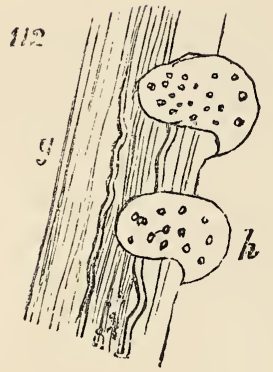

Fig. 111. - Physalia utriculus, "Portuguese man-of-war' (natural size), original by Professor Huxley - $a$, the bladder, or fusiform cœnosarc, containing the pneumatophore and its cyst, which occupy all the central unshaded parts ; $\grave{a}$, the crest, which can be depressed or raised at the will of the animal-b, the long tentacles reduced one inch in the figure) $-d$, the short ones $-c$, the polypites-e, the tentacular sac - $f$, velvety masses, which consist of small polypites and their tentacles.

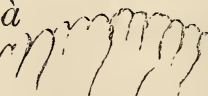


like the tentacles and polypites, with thread cells, which the animal can at will discharge, paralysing its victim or enemy. The "Portuguese man-of-war," therefore, consists of a large bladder-

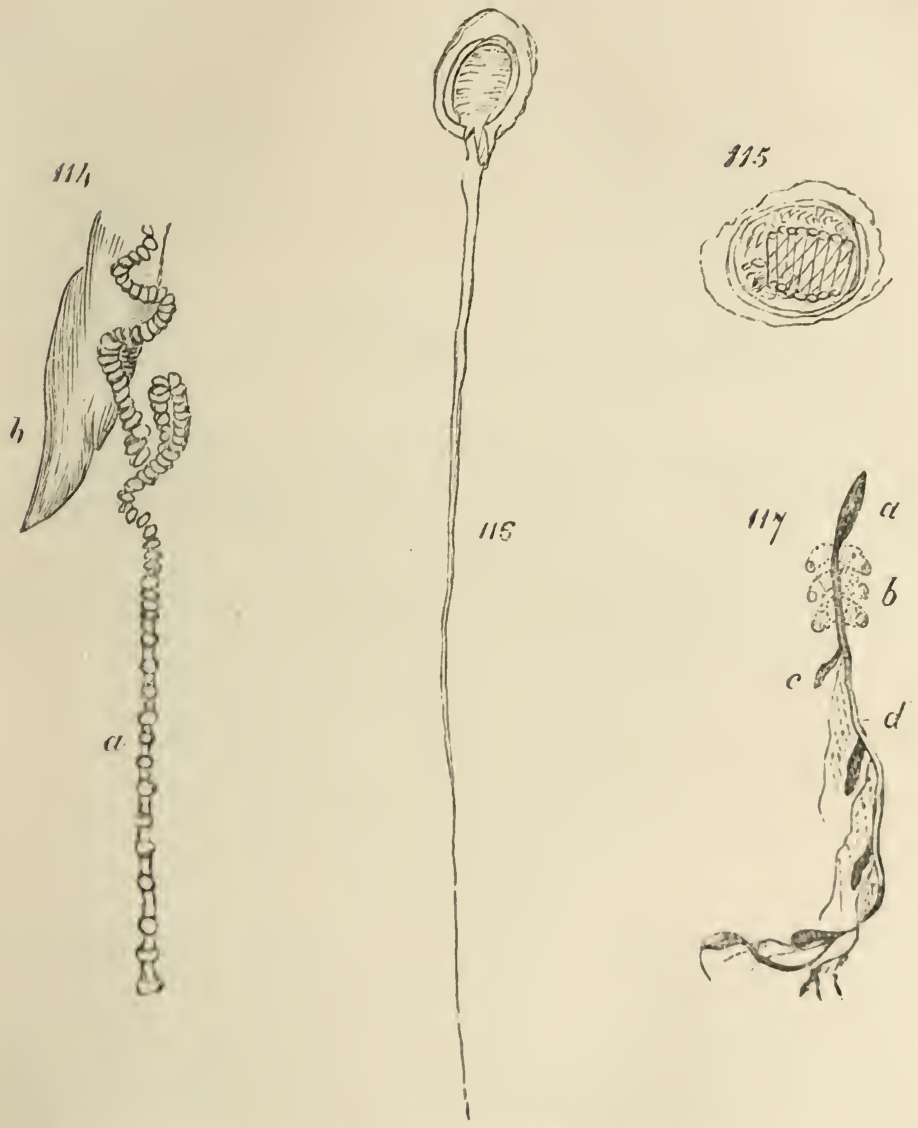

Wh. 114. - 1 tentacle of $I$. ulriculns (a), an it is attached to lta basal sac, $b$.

Fig. 115,-Ono of the "throul polls" tuagnitled.

Flg. 116.-The sume after le han diacharged its threval.

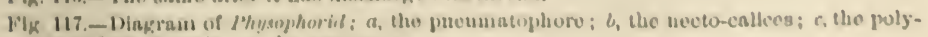
filte and les tontaclo; $d$, the comosare.

liko conosare containing a pneumatophore and its pueumatocyst. From the conosare depend tho polypites $(c)$, the tentacles ( $b$ and $d)$, 
and the coeal appendages (e). It has the power of contracting and dilating its crest, and can turn over or perform somersaults on the surface of the sea, but when adult it has not, as far as is known, the power of guiding itself or sinking to the bottom.

In 1862, Mr. Tudor, writing to the Times, stated that a considerable number of "Portuguese men-of-war" had been that summer washed on to the shores of the Dorsetshire coast, and he remarked that, as an old sailor, he never remembered seeing them before north of $48^{\circ}$ lat., and then only in the Gulf Stream. Mr. Tudor thought that the appearance of these tropical creatures on our shores indicated some extraordinary change in the course of the Gulf Stream.

For more minute points connected with the economy of the Physalia-and there are many very interesting-I must refer the reader to the complete and clear description and illustrations of Professor Huxley, in his "Oceanic Hydrozoa," published by the Ray Society.

The Physophoridæ are divided into seven different families, most of them consisting, as far as is at present known, of single genera. They are all most interesting subjects of study to the naturalist, but do not come within the scope of this work.

The next order of the Hydrozoa comprises a large and most, interesting class of animals-viz., the Medusidæ, or so-called "jelly fish " of our sea-shores.

\section{CHA P TER IV.}

\section{The Medusid सE.}

There is something very elegant and graceful in the glistening Medusa as it rolls through the clearer waters of the sea in a hot still day in July. The marvellous transparency of the creature, as it bobs up and down by the side of the boat, renders it all but invisible to the eye of the observer. But, fixing his attention upon some coloured radiating markings, he will gradually realise the fact that he is looking upon a semi-globular living thing, with a central body and several tentaculæ dependent from its rim. If, again, the observer goes on to the shore at night, or sails along the warm coasts of Italy, he may see hundreds of thousands of bright sparks of light, or it may be balls of fire as large as small oranges, moving through the water. In the day observation the weather must be still and calm; for his nocturnal visit, the sea should be 
more or less rough, for phosphorescence, upon which the light depends, is only produced when the creature is irritated.

The Medusa_or "jelly fish," or "sea blubber," as it is sometimes called-consists of a more or less hemispherical or globular mass of sparkling crystal-like jelly, arranged in the form of an umbrella; and hence this part of its body is, in scientific language, called the "umbrella." Underneath, however, the analogy to the umbrella is somewhat lost, for, to make the resemblance complete, we should carry the dilating wires of the umbrella to the edge, and cover them in beneath with another piece of silk-we should then form what is in scientific language called the "sub-umbrella." Were the stick of

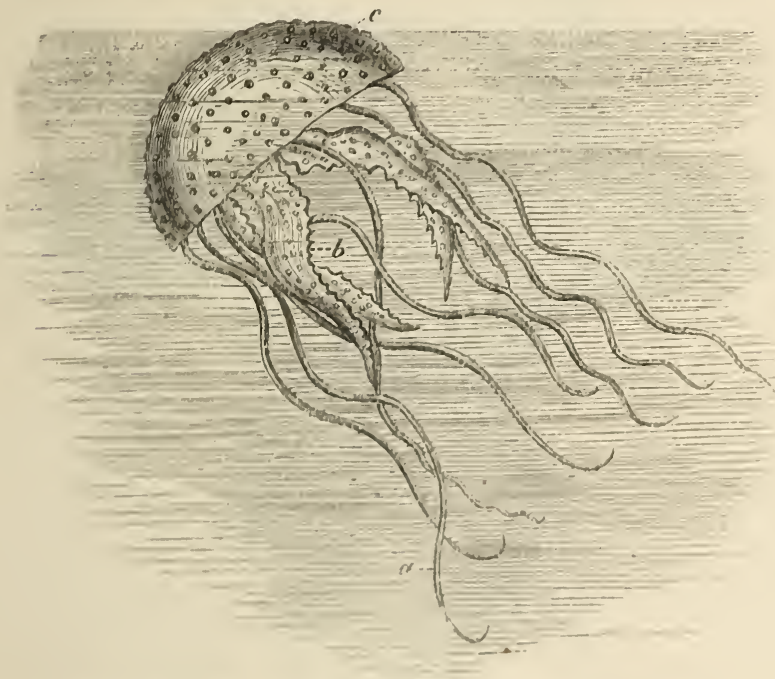

Fig. 118. Pelayia cyanea $-a$, tentacles; $b$, arms; $c$, umbrella.

the umbrella cut off a few inches below where it would enter the centre of this sub-umbrella, it would represent the dependent polypite of the Medusa, which again is either singlo or divided into what are called arms, as shown in Fig. 118 and Fig. 119 (p. 9.1).

But the reader must imagine further, that, where the polypite depends from the sub-umbrolla, there is in the Medusa a carity in the gelatinous substance, and that this cavity communicates, on tho one hand, with the polypite, and on the other, by means of four, six. eight, ten, or more canals, called "radiating canals," with the rim of the umbrella (Fig. 122, 6, p. 96). Round the rim of the umbrella is 
another canal, called the "marginal canal" (Fig. 122, e, p. 96), from which for the most part depend a series of tentaculæ or . organs of prehension (Fig. 120, $h$, and Fig. 118, $a$, p. 93). Besides these tentacles, and placed at their base, are a series of brilliantlycoloured spots called ocelli, and which, though not eyes, are considered to be sight-giving organs; also a series of vesicles or bulbs which, though not ears, are considered to be sound-giving organs ; and these two becoming united together, have received the name of "lithocysts" (Fig. 121, d), for sometimes a bright crystal of silex is found in their centre. In addition to this, there is in the majority of species according to some systematists, and in all of the true

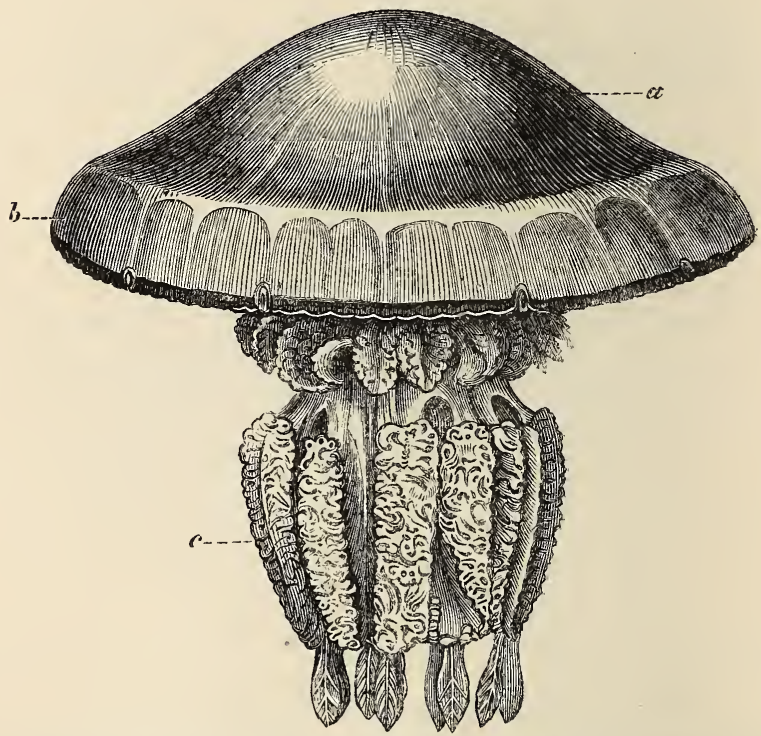

Fig. 119. - Rhizostom $a$ Cuvieri- $\alpha$, the "umbrella," with $b$, its scalloped edge; $c$, the eight thick foliaceous arms, which, when the animal is in the water, are spread out and seize the food.

Medusæ according to others, a velum or veil, which is suspended from the rim, as shown in Fig. 120, e, and Fig. 122, $d$ (p. 96). Now, between the radiating canals and the apex of the semi-globular nectocalyx, or swimming bell, as the umbrella may be called, there is more or less of the gelatinous, sparkling-looking substance of which the creature is composed. This is membranous and cellular in its character, and contains a clear fluid. It is non-contractile and 
elastic, but not extensile. But this nectocalyx is distinguished at once from that of the Calycophoridæ, by the absence of the locomotive organ termed the nectocyst. A higher means of locomotion is, however, provided for the Medusæ. A fringe round the mouth of the polypite and the margin of the umbrella, as well as the substance of the tentacles, are formed of granular substances, and of

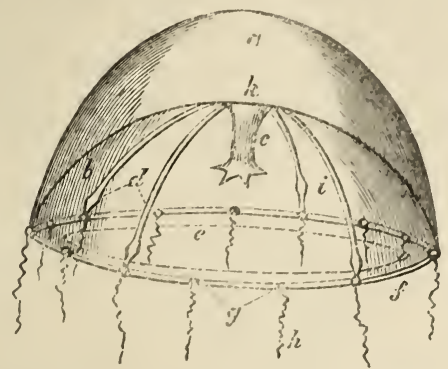

Fig. 120.-Meduse, in proflle (tho central and opposite parts are easily seen through the bright sparkling substance of the animal) - $a$, the umbrella; $b$, the sub-umbrella; $c$, polypite; $d$, radiating canals; $e$, velum (shown by dotted lines); $f$, marginal canal; $g$, lithocysts; $h$, marginal tentacula; $i$, roproductive body; $k$, manubrium.

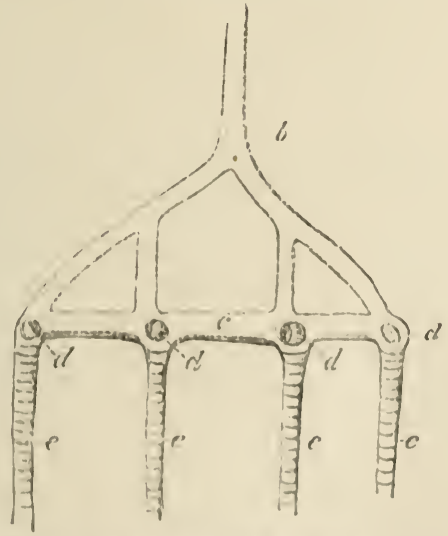

Flg. 121.-a, portion of rmlinting emals (magnlflod stlll uoro); $b$, radinting canal; $c$, mar-

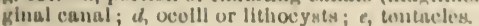

this structure there raliates from the rim and along the subumbrella a series of musculur bunds, and it is by the contraction of these that the ereature mores. Such is the simple structure of these beatiful creatures; and yet, though simple, mark how we are rising in the seale of being! 
We have now membranes forming cells, and canals carrying nutritious fluid; we have at all events something like an eye and an ear; and we have undoubtedly motion produced by muscular fibre-not as in the Calycophoridæ, by working a pneumatic apparatus, but by direct contraction. It is true we have hitherto no evidence of a nervous system, but there is yet something to learn in the economy of the Medusæ. The tentacles are, like those of Physalis, hollow tubes, and some of them are provided with thread cells, and sting severely. They have at their extremities and sides sucker-like processes by which to retain a better hold of their victims, or, as is supposed by some, to enable them to anchor, and

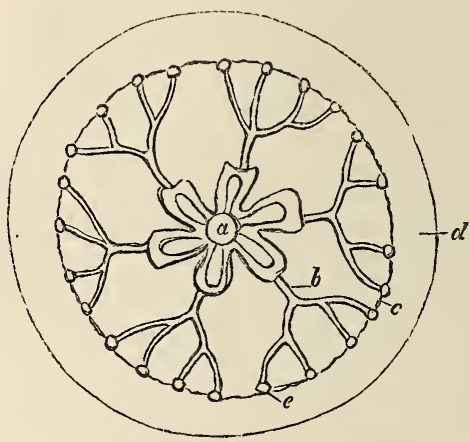

Fig. 122. - Willsia stellata (after Forbes), seen from above- $a$, star-like ovarium; $b$, radiating canals dividing and opening into marginal canal $c$; $d$, velum; $e$, ocelli (magnified).

"rest and be thankful," when so disposed. Some of the Medusæ attain a large size, like the Rhizostoma Cuvieri mentioned by $\mathrm{Mr}$. Francis as having been found by him on the Cornish coast, and recorded in the Field of May 19, 1866. I append a figure of this monster Medusa, whose umbrella, in Mr. Francis' example, was two feet across and dependent polypites the same length (Fig. 119, p. 94).

The Medusæ are divided into two sections, according as the ocelli or lithocysts above mentioned are naked or covered. The former have been well described and figured by the late Professor Forbes in a work published by the Ray Society.

None of the "naked-eyed" Medusæ have the power of stinging the human hand, though it is probable their thread cells may be able to pierce more delicate structures. In the "covered-eyed "Medusæ the ocelli are concealed by membranes or hoods. And two of the families, owing to the absence of the velum-viz., Pelagia and 
Rhizostoma, are placed by many systematists in the next and last order, the Lucerniadx.

Among the covered-eyed species of Medusø, two species are very common on our shores. First, Aurelia aurita; this when seen floating through the water is readily distinguished by four crescentshaped purple markings, which are discerned through the gelatinous disc or umbrella. This species is very abundant all along our coasts, sometimes, as Forbes remarks, impeding the progress of boats. I need not figure it, as any one may get it for himself. It does not sting.

The other common species on our coasts, Cyanea capillata, does, however, sting severely. It is distinguished by its flatter disc, "of a pale yellow colour, deeply scalloped at the margin into sixteen quadrate lobes, between each pair of which in a deep notch is a conspicuous pedunculated ocellus. Eight brownish rays proceed towards these ocelli from a circle of reticulated, quadrate, brown markings, giving the whole disc a beautifully stellated appearance, which depends on the organs on the sub-umbrella, which is furnished with long plicated and furbelowed membranous arms and fasciculi of extremely extensile stinging filamentary tentacles" (Forbes).

The Medusa which I illustrate at Fig. 118 (p. 98) is a species which has been taken occasionally on our shores, but is well known to those who lave sailed on the coast of Italy, where it looks, owing to its phosphorescence, like a ball of fire in the water. It is a very beautiful creature. The disc is of a rich rose colour speckled all over, especially at the sides, with orange-coloured warts. Its margin is divided into sixteen lobes, from beneath eight of which spring eight long tentacles, while in the remaining grooves are eight red covered and stalked ocelli.

The species as shown by Fig. 119 (p. 94) deserves one or two romarks. As a rule, the appendages which hang down from the centre of the umbrella are connected with the polypite. whose month they cover and provide with food. In Rhizostomu Cuvieri. however, the arms end in distinct polypites, each having a small opening or month at its extremity; this is the commencement of a canal which, after diviling freely in the arms, terminates in a large stomach which is covered in by the second tier of fringes in the figure. It has no other digestive apparatus. The stomach is not yot even froe, but remains, as in the Hydra, a hollow in the substance of the polypite, with its inner and outer skin.

There aro six genera of "covered-eyol" Medusa described as occurring on our sea-shores, but the number of speeies is only eight or nine. Clurysusere hy/soscellu has curious ribbon-like appendages, 
which float at great length in the water, mingling with a large number of marginal tentaculæ. The disc " is yellowish or reddish, marked with more or less distinct pale rays, and often spotted with brown at the margin" (Forbes).

Of the "naked-eyed" Medusæ, Forbes has described eighteen genera and figured forty-three species in his beautiful monograph from which I have already quoted.

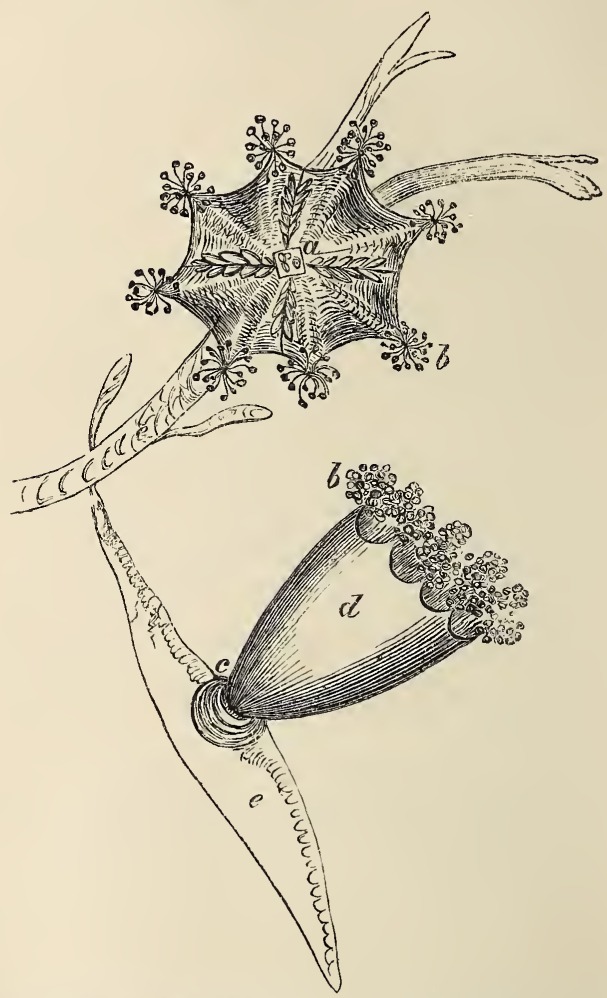

Fig. 123.-Lucernaria campanulata, as seen from above, and in proflle-a, mouth of polypite; $b$, tentacles; $c$, hydrorhiza, or root of polypite; $d$, the umbrella; $e$, seaweed.

The Lucernaridæ are the last group of the Hydrozoa. I propose to restrict them, without going into the question of classification, to those known as constituting the family Lucernariadæ, in which there are no ocelli, and which have the umbrella everted and fixed by a hydrorhiza, as shown in Fig. 123. These small but beautiful 
organisms appear like Medusæ turned upside down, being generally about an inch in height. Their attachment by the hydrorhiza $(a)$ is not permanent. $\Lambda s$ shown in the figure, the tentacles $(b)$ are eight, sometimes nine in number, and appear like tufts of flowers round the rim of a glass vessel.

The granular matter of which these organs of prehension aro composed passes between membranous folds and terminates in a rim surrounding the mouth of the polypite $(a)$. In another genus, Carduelia, these tentacles form a complete rim round the edge of the cup. They have generally sucker-like appendages at their extremities; but in others they are club-shaped, like those in the Zoophyte, Coryne.

The Lucernaria are of a pink colour, and can close in their cup by the contraction of a series of muscular fibres which pass round its rim and radiate towards the polypite ( $\iota$, Fig. 123). By the alternate opening and shutting movement thus produced, they sometimes swin through the water, with their cup everted, in a respectable Medusa-like fashion. Most of the writers since Jolnnston's day have copied his figure of Lucernuric auricula. It is only fair, therefore, to give his other figure, L. cumpanulata, a like chance of popularity, which I have accordingly done.

\section{CHAPTER V.}

\section{Reproduction of the Hydrozon.}

THe Phosphorescence of the Sea is a subject of sufficient interest and importance to merit a short space before we close the history of the Hydrozoa.

Almost all the Medusa and Physalia and some of the corallines among the Hydrozoa are phosphorescent, and no one can have witnessed this phenomenon, even as seen on our own shores, without being struck with its singular and weirdlike beaty. In other countries it is even more striking.

Mr. Bomyeastle thus describes a scene of this kind which he saw on the 7 th of September, 1826, in the Gulf of St. Lawrence:-

"While it was very dark a brilliant light, like that of the aurora. was seen to shoot sudidenly from the sea in a particular quarter. It spreal thence over the whole surface of the water between the two shores of the gulf, and shortly there was presented one blazing sheet of uneful and most brilliant light, in which many large fishes wero 
seen darting about as if in consternation. The light was sufficient to enable me to see the most minute object on deck. On drawing up a bucketful of water and stirring it with the hand it presented one mass of light, not in sparkles as usual, but in actual coruscations." -Trans. of Literary and Historic Society of Quebec.

The animals chiefly concerned in marine luminosity are those we have already dealt with. The most common, perhaps, of all is a small animalcule which occurs in countless myriads in the sea-viz., the Noctiluca miliaris. This curious creature is one of the Amcebæ. After the Noctiluca the Ccelenterata supply the greatest number of light-giving creatures. When individual objects are discerned the phosphorescence is caused generally by one or other of the covered-eyed Medusæ or Pelagia, and the scintillations so often noticed are produced principally by one of the small naked-eyed species-viz., Thaumantias lucifera, a beautiful creature about the size of a split pea, having round the rim of the umbrella no less than eighty-four tentacles. As to the cause of phosphorescence a great deal has been surmised. All modern scientific observers agree in the fact that it is produced by animal motion; that it is therefore a vital act, and not a consequence either of slow combustion or the production of a phosphorescent body or mucus. The light is clearly electrical. Kölliker believes that the luminous organs are a nervous apparatus similar to the electrical organs of fishes; but this presupposes the existence of a nervous eystem in animals where it has not been discovered by the strictest examination. The one great and prominent function of the sarcode of the Amobæ is, as we have seen, that of motion; and this sarcode is differentiated in the higher animals into muscular tissue. It is not, therefore, very difficult to understand how such motion may be accompanied by electrical discharges, and thus constitute the phenomenon known as phosphorescence.

In the Medusø it is probable that the light is more or less connected with the discharge of those curious thread cells of which I have said so much. Forbes remarks that he never saw phosphorescence in the naked-eyed Medusæ spring from any part of the body except the tentacles, and all writers refer to the lithocysts as more or less connected with the phenomenon. Now, as we have seen, these parts of the bodies of Medusæ are the principal seat of the thread cells, and the inference I have drawn is, I think, supported by the fact that a Medusa, when fresh caught, will emit light when irritated, but that by a repetition of the process the power soon ceases, which would naturally be the case when all the thread cells were discharged. Forbes, however, says that none of the naked-eyed Medusæ have the power of stinging. But it must not be inferred 
from this that they have no "thrcad cells," as they would in such minute creatures evidently be too small and delicate to pierce the thick human skin. It is certain, however, that the genera Turris, Occana, Dianea, and Thaumantias arc all phosphorescent. This phospliorescence must not be confounded with that produced by terrestrial animals like the glowworm and lantern fly, in whom a special apparatus exists, and which is evidently designed, in the onc casc at least, to guide the malc to its mate. The same result may be produced by very different means, and we often see this in our study of Nature and her laws. All analogy points to the probablc inference that the power of emitting light is given to the lowly and graccful Medusa as a mcans of protection from danger. The subject is onc of interest and importance, and I commend it to the study of those who have the time and opportunity for such investigation.

The Reproduction and Developuent of the Hydrozoa next claim our noticc, and the facts to which I beg the particular attention of those who study natural science are very curious and interesting. I have beforc detailed one of the modes by which the common freshwater Hydra is reproduced-viz., from buds like a plant. But the creature which thus increases itself by buds was itself the product of an egg! Such at least, I ought to have said, might have been its origin, for the Hydræ multiply by cggs as well as buds. Yet a third way remains to be mentioned by which these singular creatures can be reproduced. They can divide themselves into one or more parts by what is termed fissipcration. We are told by a German writer, Jiiger, that he has observed specimens which he had kept warm divide themselves into different portions, each of which became encysted like Vorticclla (ante, p. 33). Jiiger suggests that these encysted portions of Hydrow would hybcrnate in this condition, and in the spring each would come out a veritable fullyformed Hydra. Although Jiger has not, I believe, substintiated the truth of this suggestion, all analogy gives it a higher degree of probability. A great deal of the surprise which these statements create is romoved when it is considered, first, that all eggs or ova are more or less of the nature of buds themsclves; and, secondly, that even as high in the seale as insects, the development of young may take place by internal budding without the direct intereourso of the soxes." Every practical entomologist knows this. Bearing these facts in mind, lot us look at the details in the lifo history of the

* This fact, as fur as tho uphidna arn concormed, has been latoly reudered doubtful by tho oxperimunts of the physiologist Balbiani, who considers all the aptoroum aphicles as true hermaphorites. 
next family of the Hydræ, the Corynidæ. In these and other Zoophytes, as well as in the Calycophoridæ and Physophoridæ, the germs are carried in a large conspicuous cell (Fig. 102, $f$, ante, p. 79, and pp. 81, 82, 84), which, by reason of its office as a bearer of germs, has been called by Professor Allman a Gonophore. Fig. 124 represents the Gonophore of one of the club-shaped Zoophytes full of young germs. Fig. 125 shows us the same Gonophore after it has opened at one end and given exit to the embryos within it, one

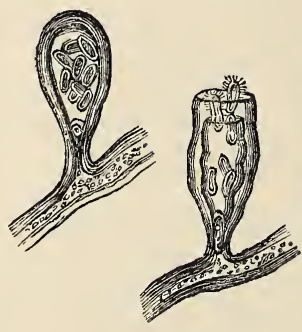

Fig. 124. Fig. 125.
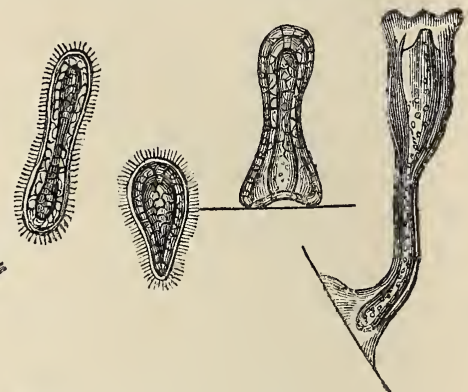

Fig. 126. Fig. 127. Fig. 128. Fig. 129.

of which, provided with a row of cilia by which it can swim through the water, is seen at Fig. 126. By and by we find it assuming a pear-like form, as seen at Fig. 127, and then becoming attached, as shown at Fig. 128, it is developed into a primitive polypite (Fig. 129), which is the founder, by budding, of a colony similar to that seen in the corallines, and which I fully explained, and illustrated, ante, pp. 79-84. All this was beautifully worked out by Professor Allman, and published by him in the Philosophical Transactions for 1863 .

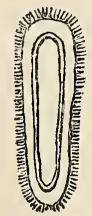

Fig. 130

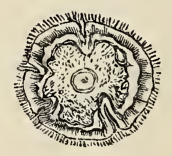

Fig. 131.

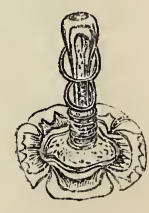

Fig. 132.

In the Sertularidæ the changes are still more interesting. In these Zoophytes the Gonophores (Fig. 104, p. 81) contain germs which are exactly like Medusæ, and have, in fact, been taken for such by naturalists. These Zooids, as they have been termed by Professor Allman (Fig. 130), after swimming about by means of 
their cilia, become at length fixed, and after a time have the appearance of flattened discs (Fig. 131) surrounded with a close fringe of cilia, and showing a tendency to divide in four places. This disc becomes, in fact, the root or hydrorhiza, and from the centre is developed the first polypite (Fig. 132), which by budding grows into the tree-like Zoophyte or coralline which we pick up on the seacoast, and magnified drawings of which I have given ante, pp. 79, 81 , and 82. While the facts connected with the reproductive phases just described are fresh on the memory, let us follow out the life history of one of the Medusididæ.

It will be remembered that, in describing these forms in the last chapter, I pointed out ( $i$, Fig. 120, p. 95) a swelling in each of the radiating canals just before it terminates in the marginal canal. This is the reproductive body, which contains the eggs or embryos. These when first emitted are covered with a gelatinous investment, and have the appearance shown at Fig. 133, but which in a free condition are like Fig. 134. The product of one of these eggs is an animal known to naturalists as an hydra-tuba, and in its early or very young state is represented at Fig. 135 with four marginal tentacles in the process of development. In a short time these tentacles become doubled, and the creature fixes itself by its hydrorhiza, as seen in Fig. 136. The mouth now becomes enlarged, the tentacles again divide, and the creature becomes, in fact, as nearly as possible a fac-simile of the fresh-water Hydra (Fig. 137), in which

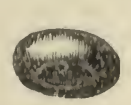

Fig. 1i3is.

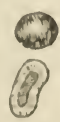

likg. 1:1.

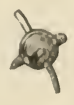

Nig. 1:5.5.

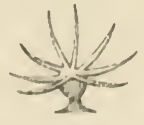

Iié. Isti

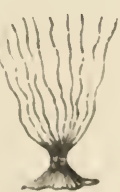

Fin. $1: 3$,

condition it may remain for yeurs, budling and sending off young Hydras exactly as the Hydra does. But all this time it is only in a transitional condition. Wo must not forget that we are talking now of the product of an egg deposited by one of the linge Medusw, or so called " jolly fish."

'The intelligent reader will also remark that while the corallines in their dovolopment pass through the form of Merlusa, these latter return the compliment by assuming the form of the polyp. This constitutes what is temued parthenogenesis, or alternation of generations, in which the ehild is nower like its parent until it has passed through a period of existence of indefinite length, during which period it gives birth or origin to other beings like itself, all of which, 
by another series of changes, become developed into a vastly-increased number of young Medusæ like their original parent!

We will follow out these changes by the assistance of Steenstrup's figures in the memoir which first brought the subject practically before the scientific world, although Sars and Chamisso were those by whom the facts of parthenogenesis were originally elucidated. Steenstrup's work was translated by Mr. Busk, and published by the Ray Society in 1845 , since which time its illustrations have been generally made use of by naturalists, and very often without the slightest acknowledgment.

At a period, then, in the existence of the polyp shown at Fig. 137 (p. 103), which is unknown, and influenced by the operation of a law which is constant-although the nature of the force which brings the law into operation is also unknown-this polyp shows a tendency to divide just below the insertion of the tentacles. Instead, however,

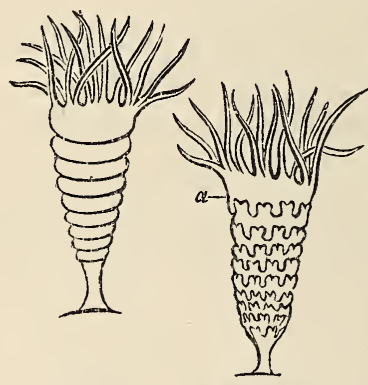

Fig. 138.

Fig. 139.
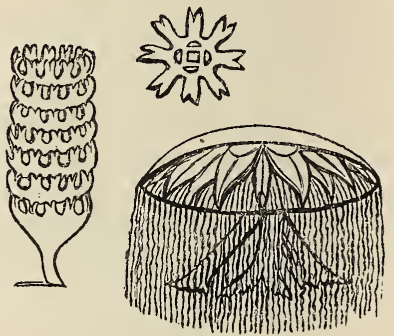

Figs. 141, 142.

of dividing at once, the body of the polyp increases in size in an upward direction, showing as it does a series of distinct circular markings (Fig. 138). After a time it presents the appearance shown in Fig. 139, where it will be observed each circular marking has become crenated by the growth of processes having an upward direction. The animals or larvæ now begin to separate. The first one coming off at $a$ (Fig. 139), which is called by Steenstrup the "polypiform nurse," becomes fixed by a root or sucker-like extension in the centre of the umbrella, and is termed by him a "stationary Medusa."

Leaving, however, the history of this "stationary Medusa," we find that, after it has separated, the pile assumes the form of Fig. 140, which is nothing more nor less than a series of young Medusæ, having now no connection with each other, but which speedily separate and grow up into the full-grown "jelly-fish." 
When first separated they have the appearance shown at Fig. 141, but speedily appear as at Fig. 142, with their umbrellas and tentacles, and grow up gradually until they attain the form and size described and illustrated in the last chapter.

Such are some of the remarkable facts connected with the reproduction and development of the Hydrozoa. M. A. De Quatrefages, in an admirable little book, "The Metamorphoses of Man and Animals," which has been well translated by Dr. Lawson (Hardwicke), goes fully into the curious subject of alternation of generation, and concludes his fourteenth chapter in the following words :-

"What would our readers think were we to express ourselves thus? $\Lambda$ butterfly deposits an egg from which springs an earthworm that is soon converted into a caterpillar. From this caterpillar a series of buds are produced which become so many individuals like the first one; then each of these, although preserving the caterpillar head, assumes the body of a chrysalis; this body is constricted at intervals, and gradually becomes converted into a cluster of butterflies piled up one upon another; the caterpillar head then falls off, and the butterflies fly away one by one. At first they resemble moths, but by degrees they assume their true characters, and become beautiful diurnal Lepidoptera. Who would put any trust in a history which described a series of transformations as fantastic as those seeu in a dream? Yet change a few of the expressions, employ the terms Acalephr, and Medusæ for those of insects and butterflies, and that which a moment before had been fiction becomes simple truth."

\section{H A P T E R VI.}

\section{THe ACtiNozos.}

TrF Actinozor form the second division of the Colenterata, and they are at once and definitely distinguished from the Hydrozoa by possessing a stomach which is freely suspended in the body of the animal ; whereas, as I lave already pointed out, this organ in the Hydromoa is merely hollowed out. as it were, in the substunce constituting that creature's corporeal structure. This is not a mere fanciful distinction raised up by arbitrary elassifers to make their arrangements more definite; it is a great step in the upward progress of the living being towards that perfection of structure which we see in man and the higher animals. I thot down the 
great points as we go on in order that those who take an interest in these illustrations may mark, learn, and inwardly digest the great plan upon which living structures are built up. Henceforth, then, in the scale of life we shall find a free stomach in the subject of our study. It is the first truly differentiated organ we have hitherto met with; and this fact will be impressed on the reader's mind evermore if he will note therein that this occurs in the Actinozoa, and that the type of this division is the well-known seaanemone of our coasts.

But, to assist his memory, I will give diagrams illustrating the difference in this respect between the Hydrozoon and the Actinozoon.

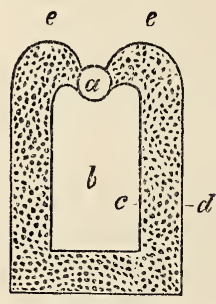

Fig. 143.

Longitudinal Section of Hydrozoon.

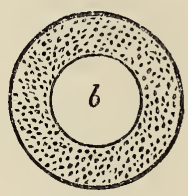

Fig. 144.

$a$, mouth $-b$, stomach $-c$, endoderm $-d$, ectoderm $-e$, tentacles.

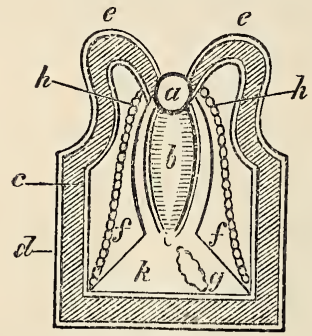

Fig. 145 .

Longitudinal Section of Actinozoon.

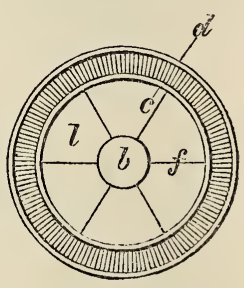

Fig. 146.

Transverse Section of same.

$a$, mouth- $b$, stomach-c, endoderm- $d$, ectoderm-e, tentacles $-f$, lamellar plates, or mesenteries, which divide the somatic cavity into what are termed-l, loculi $-h$, ova or germs $-g$, body containing thread cells $-i$, opening of stomach into $(k)$ the somatic cavity.

Fig. 143 is a longitudinal section of a Hydrozoon, and Fig. 144 a transverse section of the same; while Figs. 145 and 146 represent similar sections of the Actinozoon. The letters indicate the same parts in each figure. Now, mark that the stomach $(b)$ is in the Hydrozoon hollowed out, as it were, of the body substance, while it 
is seen suspended into the somatic cavity in the Actinozoon. The stomach of the former is only separated from the external world by the endoderm $(c)$, the ectoderm $(d)$, and the intervening sarcode. In the latter there is seen at $k$ a wide space between the free depending stomach $(b)$ and the body wall at $c d$. And this space is found to bo divided into partitions, which are occupied by certain organs $(g h)$, and communicate above with the hollow tube called the tentacle, as diagrammatically represented at $e$. Now, a brief examination of these partitions and organs will reveal to us the morphology of the Actinozoon, and show us how far upwards we have now reached in the scale of organised nature.

From the mouth ( $a$, Fig. 145) is seen dependent the stomach $(b)$, in a kind of hollow formed between the inner plate of the partitions. At $i$ the stomach opens into the somatic cavity (k), where the digested food serves the purposes of nutrition, the useless reliquire being returned through the same opening.

Now, in this lowly and beautiful flower-like animal there are shadowed forth structures which are fully developed in the higher class of animals. Let us illustrate this :

The body wall ( $c d$, Fig. 145) consists of two membranes, the ectoderm $(d)$ and the endoderm $(c)$, and between them, as shown by the lines, are two distinct classes of muscular fibres, by which the animal contracts or dilates itself at pleasure. The ectoderm $(d)$ is, however, itself divisible into two membranes, the outer one resembling the epithelium, and the under layer the derma, or true skin of the higher animals; and between these layers of skin are imbedded vast numbers of thread cells and the pigment granules by which the beautiful colours of the anemone are produced. The endoderm(c) may also be separated into two layers, one of which is in contact with the muscular structure; the other is free, and forms one of the boundaries of the partitions, as seen at $c$ (Fig. 146). Both the endoderm and ectoderon have their free surfaces covered with the hairlike bodies, which I described in a former chapter, termed cilia. The stomach is a simple thin sac, also of two layers, having its inner surfaco covered with cilia (b, Fig. 145).

In the muscular structure between the endoderm (c) and the ectoderm $(d)$ we have a foreshadowing of that important part of animal organisation which we know so well in our own bodies. There are two kinds of muscle in this covering of the Actinozo:l-a longitudinal series of fibres deeply seatod, and a cireular series, superficial. Each of the partition walls ( $f$. Fig. 1fii) has two muscles on its surface, and the muscular fibres of the stomach enable the opening (i) to close or open at the will of the animal, while the tentades (ec) are moved by similar structures. The contraction of the animal itself and 
its dilatation, which most people have often observed, is due to the alternate action of the horizontal and circular fibres. By examining the diagram the student will observe that both the tentacles and the stomach are prolongations of the body wall, and therefore are similarly organised. At $h$, Fig. 145 (p. 106), is shown a string of beadlike bodies, which are ova, as seen in the female; for, although the Actinozoa are propagated both by budding and fissiperation, there is also a true mode of reproduction by sexes which in the seaanemones are distinct, although not recognisable by any external character or any mode of examination except that of the bodies seen at $h$ by the microscope. At $g$, Fig. 145 (p. 106), are shown what represents the convoluted filamentary bodies, which contain thread cells, and which the animal can emit outwardly through minute orifices in the skin, called by Mr. Gosse "cinclides."

In translucent specimens of the sea-anemone, the six partitions formed by the six lamellæ ( $f$, Fig. 146, p. 106) can be clearly seen, and it may also be observed that these lamellæ do not go to the bottom of the somatic cavity; consequently, the spaces formed by these "mesenteries," as they are termed, all communicate most freely with each other. A nervous system has not been yet discovered in the actinea, or sea-anemone; but as it undoubtedly exists in some of the other Actinozoa, it probably only awaits the discovery of some worker more successful than any has hitherto been. In the margin of the disc of the sea-anemone there are sometimes observed some bright blue specks, which have been thought to be organs of vision, of course in a very rudimentary condition.

The thoughtful reader will not fail to remark that we have now arrived at a decided step in advance in the organised scale of animal existence, not only in the existence of a free stomach with a sphincter, or muscular structure, by which the opening of the stomach into the somatic cavity ( $i$, Fig. 145, p. 106) is closed and opened according to the necessities of the creature's existence, but also in the differentiation, as it is termed, of the sarcode, of which we have spoken so frequently in our previous chapters, into a system of muscles having both flexor and extensor fibres-not as we see in the Calycophoridæ, merely in the formation of an apparatus for the special purpose of locomotion, but pervading the whole body, substance, tentacles, and stomach of the animal.

Now this word differentiation simply means a fact which we cannot explain. Sarcode is the ultimate pabulum, or basis, of all animal structure. It not only exists in the lowly Amœba, but is the main constituent of all animal bodies. By the vital principle this sarcode is changed, or altered, or differentiated into muscle, bone, brain, nerves, blood vessels, tendons, lungs, heart, and all the alimen- 
tary and other abdominal organs of man himself. But of the essence or nature of the vital principle we know nothing. The physio-chemico philosophers of modern days have endeavoured to identify it with correlated force, and to compare it with the power which forms the dead crystal. With what success this has been done may be found in the new edition of Todd and Bowman's "Physiology," where the masterly genius of Professor Beale has shivered such a notion into a thousand atoms, none of which will ever again gain either power or coherence. No; the vital principle, the first puzzle of all writers, is an ultimate fact which cannot be explained by a finite mind. Chemical force can, by its power of attraction, select the object with which another combines, and the result is a crystal and a definite thing in nature; but that force cannot say to the dead crystal, live, and feel, and move, and think. Neither can such a force say to the ultimate structure or cell, when living, grow and form muscle, or nerve, or bone, or brain. The Power which does this is incomprehensible to the human mind, and it is simply because the finite can never, from the nature of things, comprehend that which is an attribute of the Infinite.

The sea-anemone is a pleasing study to the sea-side naturalist, and to those who in their aquaria have a miniature sea in their drawing-room. This is a subject over which the genius of a Gosse lingers gracefully, for has he not written a book which leaves little or nothing to say of all the family? - and has he not told us "who is who," and given us beautiful portraits of the various branches, relations, and connections of the Actinix? Perhaps what I have written may givo an additional interest to the study of his book, for it is surely not my intention, even had I the space, to attempt any extracts from its pages.

But we will follow the sea-anemone from the coasts of Devon to the soft balmy seas of the Pacific, and we will there show how great and important an agent it has been in the fimmution of the world. Wo will look into the clear deep blue sen, and search there for its whereabouts, and, if the eyo is gladdened and the fancy chamed by the panorama we witness, we shall not be in a less fitted state of mind to ponder upon the grand facts which the history of the Coral will unfold. The very name is suggestive, and its utterance carries us back mentally to the diy's of our boyhood, when the mere sight of those beautiful masses of curionsly-wronght limestone used to transport us in imagination to the Cocoa-Nut Islands and the fieree savage of the Sonthern Seas, of which wo hat read in those thrilling tales of adventum like liobiuson Crusoe, which nake such an impression on the youthful miml. How often, too, do we look upon the earefully-tended glass-corered specimen as a link which connets us 
with the past, and perpetuates the living memories of some dear friend or relative who has long since found his rest in the deep sea. But there is no part of the interest attached to the Coral of greater significance than that which we shall find connected with its history in the formation of the crust of the earth. The thousands of islands which, for the space of sixteen millions of square miles, are found in the great Pacific Ocean are almost entirely formed of Coral. All the north-east coast of New South Wales for upwards of one thousand miles has a barrier reef of Coral. In the Indian Ocean the immense chain of islands known as Cosmoledo, Saya de Malha, Chagos, the Maldivas, and the Laccadives, are all formed of Coral, occupying a space of nearly two thousand miles. The eastern coast of Africa, from Mozambique nearly to Ajan, upwards of one thousand miles, is an immense fringing reef of Coral. The coasts of the Red Sea are almost entirely Coral. Turning again to the Indian Ocean, we find the south-west coast of Sumatra and the southern coast of Java fringed with Coral. From the northern extremity of the Celebes to the Philippine Islands, thence to Bashee, Patchow, and Loo Choo, and back again into the China Sea, we find the Paracells and other large islands all formed of Coral ; and, lastly, for I need not continue the detail, the islands of Bermuda and the West Indies are surrounded by fringing reefs of Coral.

This rapid glance at the works carried on in the present day by the polyp which forms the Coral, will give some slight idea of the immense importance which this creature has possessed in fashioning the form of the earth's surface. If we go below this and look at the records of its working in time, our astonishment will be vastly increased. Some of the most interesting problems connected with the age of the world are solved by these records. Before, however, I enter into this part of the subject, we will inquire who and what this wonderful architect can be ?

The answer is very simple. None other than a minute variety, or near relation, of the sea-anemone, whose life history we will indite in our next chapter. 


\section{CHAPTER VII.}

\section{Coral.}

Tre Actinozoa are divided into four orders. The first of these, the Zoantharia, comprises the sea-anemones, including the small variety which builds coral rcefs; the second, called Alcyonaria (because the typical specics was at one time presumed to be the hardened foam of the sea wherewith halcyons build their nests), is represented by the polyp which forms the well-known red Coral of commerce, the curious horny Coral known as the "Sea-Fan" or "SeaPcn," and still more popularly by the leather-hardened foam-looking masses which the sea-side rambler recognises as "Cow Paps" or "Dead Men's Fingers ;" the third order is constituted of an extinct fossil family of Coral builders, the Rugosa; and the fourth and most highly organised is called, by reason of the serrated or comblike appearance of some of the species, the Ctenophora, all the species of which are occanic and frec.

I will say a few words about the order Alcyonaria first, because the species which form it build up their Coral skcletons in a different manner to that which is adopted by the Zoantharia. There are, in fact, two great plans upon which Coral is formed, and I will shortly illustrate both of them.

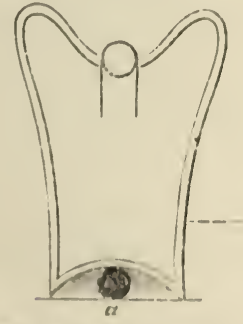

Hig. 117.-Scliro-basic.

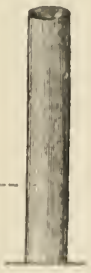

Fig 145 .

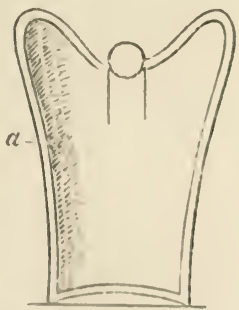

Fig. 119.-Sclero-dermic.

Fig. 117. $-a$, Cornl mecroted by outor alin of the baso of tho polyp, and extendifge from below upwarda.

Flg. 148. - Coral formul by this mem a.s seen in rod Coral of commervo.

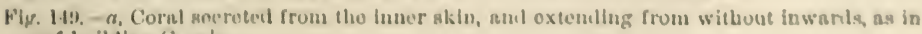
roof-builling Corals.

The figures 147 and 14 !) represent two ideal or diagrammatic longitudinal sections of Actinozoons, the former being one of the Aleyonaria, and the latter one of the 'Zoantharia. 
Now, by the vital force inherent in the polyp, a power over which the creature has no control, there is formed by the outer membrane, or ectoderm, a calcareous mass, which I have marked $a$.

We will suppose that the polyp has just arrived at polyphood, if I may coin a word, and is about to become the founder of a great colony of polyps. Well, then, having formed a starting point at $a$, the polyp increases itself by buds, or self-division; and the progeny, connected with each other and their respected parent by an extension of the ectoderm constituting a cœnosarc, also secrete Coral.

The form, the fashion, the direction of this secreted Coral are determined by the individual necessity of the polyp family. In one case it rises up a column like that of Fig. 148, which divides like a tree, the stem and branches being equally covered by the compound Actinozoon. When taken from the bottom of the sea and the "live flesh" cleared off, this turns out to be the red Coral of commerce, of which our shirt-studs and ladies' ornaments are made.

Another species prefers horn to lime, and forms the beautiful skeleton known as the Sea-Fan (see frontispiece); while still another species, having, I suppose, a literary taste, shapes its skeleton in the form of a pen, which shines at the bottom of the sea with a phosphorescence brilliant and beautiful to behold (Fig. 164, frontispiece).

Now there are three facts to be noted by the student in reference to the Alcyonaria polyps.

First, they have eight tentacles or multiples thereof. Secondly, that, although the Coral appears to be within the living mass of polyps, being secreted by the outer skin, it is in reality outside the animal ; and, thirdly, being formed by the basal part of the animal, and the Coral being very hard, naturalists have called the mode of its production by the name of sclero-basic (from skleros, hard; and "base").

If, however, the student prefers it, he may remember this, according to Dana, as Coral formed by foot secretion; not that the creature has a foot, but simply that the part of its body which secretes the Coral performs the office of a "foot."

Now, if you please, just transfer your attention to Fig. 149, which is another diagrammatic section of a Coral polyp, and of by far the most numerous family, among which are the Coral reef builders.

Observe that the skeleton is formed in this section by the inner skin, or endoderm, and that it extends from without inwards, following, in fact, the course of the partitions or mesenteries which I illustrated in the sea-anemones in the last chapter, and which may be further seen in the transverse section of a corallum (Fig. 151, p. 115). 
Now, it follows as a matter of course that as the Coral is secreted by the inner skin, it must, of necessity be inside the polyp; and it is called, by reason of its mode of formation, sclero-dermic, while the number of tentacles, and therefore of partitions, is always five or six, or multiples of these numbers. This mode of coral formation is also called by Dana "tissue secretion." In a living state the Coral in this section is also hidden by the compound animal, each polyp being connected by an extension of the internal layer of skin, or cœnosarc.

It is by Corals of this division that all reefs and most of the specimens in our collections have been formed. If the reader ${ }^{2}$ will take up one of the species which he may have in his possession, he will observe that it is made up of a number of cells, having their lamellø, or plates of carbonate of lime, crossing each cell in regular order, and forming five or six partitions or multiples thereof. A single cell of this kind is called a corallite, and several of these together a corallum, while, just as the flesh which connects the polyp is called a coonosare, so the carbonate of lime which connects the corallites of a corallum together is called a conenchymu (koinos, common, chyma, tissue). The entire calcareous substance of a Coral is called "sclerenchyma." It must be borne in mind that, however large the corallum, it has been formed by successive layers of polyps. Life and death, as in all organised nature, carry on their operations side by side. Each layer of polyps, having fulfilled their allotted duty, increase by budding or division, and die, while their progeny rear up a now stratum of Coral upon their remains. And this process goes on till vast masses of dead with a thin stratum of living Coral on its surface are formed. Thus the result may be the specimen on your chimney-piece, a small island, a reef 1000 miles long, or a rast continent like that supposed to have sunk in the Pacific Ocean, millions of square miles in extent. "What vast industry is here exhibited!" I fancy I hear some one exclaim. Not in the least. I am sorry to destroy such an illusion, for, in fact, our friend the Coral polyp is a bit of a sensualist, and passes his whole life with no care of the morrow and no thought of the past. The whole object of his life is to secure food and open his flower-like tentacles and bask in the blue waters which are warmed by the tropical sun. The Coral is made without the slightest effort on the part of the polyp. It is secreted just as our bones are secreted, whether we will or no. It is a process of life, guided by the laws of life, and perfected by the forces of life. But notwithstanding, as we shall hereafter see. this humble organism, like the Amaba of the Laurentian rocks, has been a mighty architect in 'Time.

Int us now examine into the minute structure of Coral, and take 
a peep at the life history of its builders. We shall then be better prepared to inquire about reefs and lagoons, and the coral islands of southern climes.

I have already described the sea-anemone, and stated that the Coral polyp is a diminutive variety of the same order, Actinia. Dana, a well-known American author, compares the Coral polyp to an aster, and the analogy is a very good one. The tentacles open out in a circle, and are often richly coloured, and the central disc of different tints gives a very good imitation of the China aster. Instead, however, of the stalk of the flower, we have in the polyp a broader pedicil containing the stomach, somatic cavity, and lamellar tables, as seen in the sea-anemone.

In natural history we always, or almost always, find a connecting link between distinct groups, leading, as naturalists say, from one to the other. Between the "hard basic" and "hard skin " groups of Corals this transition is effected by a clove-shaped Coral, well known as Caryophylla. This is a sclero-dermic Coral, and the transverse divisions seen in the figure (No. 171, frontispiece) indicate dead Coral, the only live portion being that at the end, where the polyps are expanding. This is quite distinct from the tree-shaped red coral stem, which forms the axis round which thousands of polyps and their conosarc are placed, increasing their stem both in thickness and length. To illustrate the history of a reef Coral, we will, however, take a more typical example. Well, then, let us suppose that the polyp of a large family, called, from their star-like appearance, Astrea, deposits an egg ; this egg is developed into a young polyp, having cilia, by which it moves through the water, as we have seen in the young Sponge. Having swum about and increased in stature, the young polyp fixes itself in some spot which its instinct tells it will be most convenient for its future success in life. Having once become fixed it lays the foundation of a colony, and it may be of an island or a continent, as we shall see by and by. Without any power or exertion of its own, the vital force inherent in its nature selects from the food taken into the stomach carbonate of lime, and with this it forms on the sclero-dermic system-not, mark, as many suppose, a house for the polyp to live in, but a beautiful, strong, and permanent calcareous skeleton, by which the delicate form of the polyp may be supported and protected. This is termed a corallite, and the creature now increases, as far as its own colony is concerned, either by dividing its own body, termed fissiperation, which takes place at the base, or more frequently by buds springing out from its side; each bud or each divided portion forms into distinct polyps, which increase themselves with great rapidity in the same way, and each having secreted its corallite, they form in their totality a corallum. 
It is quite evident that after a time the first race of Corals can extend no farther. They then die, leaving behind them a progeny which cover the old Coral of their parents. This process is repeated in some species indefinitely, each colony of course increasing the size of the corallum. In others, as in the well-known "Brainstone Coral," the size of the mass is limited. I have a fine specimen brought from Bermuda by Monsignor Virtue, and kindly presented to me, which is 54 inches in circumference and 30 inches from point to point over the apex. This is among the largest specimens.

I will now give two diagrammatic sectional figures of a corallite, one of the common reef-builders, which will illustrate the mode by which all sclero-dermic Corals are formed.

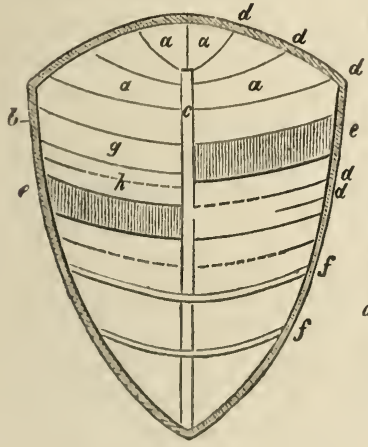

Fig. 150,-Itongitudinal Section of Corallite. (Sclero-dermic.)

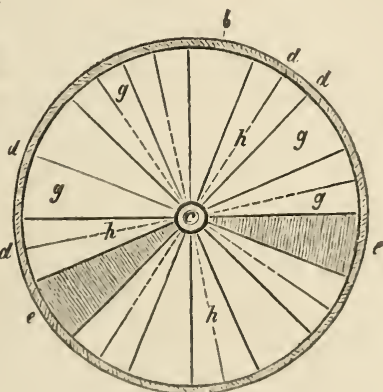

Transverse Sect

$a$, Calice or cup-b, externnl wall or theca $-c$, axis or columolla (not always present) $d d$, septa, soine complete, some incomplete $-e$, interseptal dissepiments $-f f$, tubular dissopiments $\rightarrow g y$, loculi- $h h$, pali.

It must not, however, be forgotten that the figures are what I say. only diagrams; and further, that they represent hard parts laid down by the inner skin or endoderm of the polyp, and consequently the internal form of the polyp whose history we are inditing. I am thus particular because I wish to be clear, and to illustrate this somewhat complex subject in the simplest form of which it will admit.

A longitudinal section, therefore, of a corallite (Fig. 150) represents, as seen at b, an external wall or theca, and an axis or columella $(c)$, as it is termed, in the centre of the cup-like corallite, which is not, however, always prosent.

The figures $(1, a, n, a)$ show the sectional half of the cup or calice of the corallite. The limes $(d, d)$ indieate the thin plates which are 
observed to proceed from the external coat $(b)$ to the axis $(c)$. These are termed septa, and are merely the calcified plates of the Actinia which were illustrated in the last chapter. Just, however, as we saw in the sea-anemone that the "mesenteries" were of different classes, first, second, and third by reason of their falling short, more or less, in passing through the somatic cavity, so do the septal plates of Coral, as seen in the diagrams, differ in size just as they approach more or less near to the axis. Some are seen to go from the theca to the columella; others stop short, as shown in both sections by the dotted lines $(h)$. Where the plates, however, stop short, their place is supplied by pillar-like deposits, termed "pali," which, being arranged necessarily in circular rows, are sometimes called coronets. Some of the septa go through from one side of the corallite to the other, as seen at $f$, Fig. 150 (p. 115), without touching the axis. These are called "tabular dissepiments." Sometimes again, the "loculi " formed by the septa are crossed by processes, or "styles," called "synapticulæ," which are seen at $e$, Fig. 151 (p. 115). These are called " interseptal dissepiments." I have placed the lines across at $e, \epsilon$ (Fig. 150), just to signify the fact, but of course they would not be seen in this section as shown in the diagram. The natural primary division of all zoantharian or sclero-dermic Corals is into six loculi by six septa. Secondary septa divide these into twelve, and tertiary septa again divide these into twenty-four, which is the number I have represented in the diagram 151. If any further division occurs the law now alters, and the polyp only produces twelve additional septa, being two for each primary loculus.

Such, simply, is the structure of Coral. Mark, however, that no single corallite or species of Coral possesses all the parts as shown in the diagrams. Some have one kind of dissepiment, some another; some have "pali," others have none. A diagram not being a drawing, we may take the liberty of making it useful by crowding into it all the forms which are more or less assumed by different Corals.

When the systematist steps in, he classifies according to the arrangement of these parts, and makes out a vast number of genera and species, which fall not within the scope of this work.

The forms thus assumed by Corals are various. I copy the following descriptions from Dana's "Structure and Growth of Zoophytes"-premising that in a work recently published this descriptive and beautiful passage is adopted without even quotation marks or acknowledgment:

"Trees of Coral are well known : and although not emulating in size the oaks of our forests--for they do not exceed six or eight feet in height-they are gracefully branched, and the whole 
surface blooms with Coral polyps in place of leaves and flowers. Shruberries, tufts of rushes, beds of pinks, and feathery mosses are most exactly imitated. Many species spread out in broad leaves or folia, and resemble some large-leaved plant just unfolding; when alive the surface of each leaf is covered with polyp flowers. The cactus, the lichen clinging to the rock, and the fungus in all its varieties have their numerous representatives. Besides these forms imitating vegetation, there are gracefully-modelled vases, some of which are three or four feet in diameter, whose symmetrical surface is gorgeously decked with polyp stars of purple and emerald green. All the many shapes proceed in each instance from a single germ, which grows and buds under a few simple laws of development, and thus gives origin either to the branch, the broad leaf, the column, or the hemisphere."

\section{H A P TER VIII.}

\section{Coral (continued).}

Tue passage from the Zoophytes or Corallines to the true Corals is illustrated by the Alcyonaria, which, it will be remembered, are polyps with eight tentacles or multiples of that number.

In the frontispiece (Fig. 170) is a drawing of the Alcyonium poculum, or Neptune's cup, which is sometimes, as may be seen in the British Museum, built up to a large size. These cups are the skeletons of the polyps, which are seen covering the surface inside and out with their conosare or connecting sarcode. They are found in shallow water in tropical climates, and were first discovered by Sir Stamford Raflles upon the coral reefs which surround the island of Sumatra. The texture of these "cups" is spongy in appearance and to the touch, but they contain within it numerous flinty erystalline deposits, which give firmmess and solidity to the structure. Theso "cups" are sometimes of considerable size, as much as three or four feet high, and two feet broad. Let us next examine the "Sea-Fan" (Fig. 153, frontispiece). Observe that in this (as in all but one of the other figures) I have left a part of the skeleton covered over with the living polyps and their cenosare, and I have in this instance drawn one of the polyps relatively larger to show its general form. Now, these ereatures secrete and fashion, by their vital force, this beantiful arborescent horny network, which is to servo as the skeleton of the colony. Also remark that the polyps, as seen in the figure, although to a certain extent enjoying a 
separate existence, are intimately connected with each other by the sarcode, or fleshy substance called a conosarc, which is seen between them in the figure, and upon which they appear to be located. There is another notable fact in the history of this Coral, which is that it is always built up with its edges in the direction of the tides. Were it otherwise-if, in fact, the waves washed against it " broadside on," as sailors say-its existence would be of very short duration. And yet, as I have said before, the instinct of the polyp has nothing to do with the secretion, the formation, and the mode of position of its skeleton. All this is the result of a Design quite independent of the creature itself. Several of these "Sea-Fans" have been found on our British coasts, but the most beautiful specimens come from the tropical seas. When the flesh dries it gives various colours to the polypidom. I have one brought from Bermuda, by Monsignor Virtue, which is of a beautiful purple colour. The arborescent form, as seen in the plate, is in these horny Corals singularly exact ; the stem and branches always bearing the same relative proportions as those of a tree-another adaptation of strength to resist the forces brought against it in the sea.

Fig. 154 (frontispiece) also belongs to the Gorgonidæ. It is called the Horsetail Coral, and has occasionally been taken on our Scottish coasts. It is formed partly of calcareous matter in the form of lenticular masses, as seen in the plate, which are joined to each other by thin black horny segments, which give it a jointed appearance, and the branches are thus enabled to wave about in any position in which they are placed in the water.

The name of Gorgons given to these horny Corals by Linnæus arose from the fancied resemblance of the polyp (Fig. 153, frontispiece) to the sea-deity, whose locks were said to have been changed into serpents by that spiteful goddess Minerva.

Another Alcyonarian polyp, and one which is placed by systematisers before the Gorgonidæ, is that beautiful and singular featherlooking form seen at Fig. 164, frontispiece (Pennatula grisea, or "Sea-Pen"). This graceful Coral consists of a stem resembling the shaft of the feather, one end of which is more or less firmly fixed in the ground, while after growing thick in the middle it terminates in a thin, finely graduated point. Now, this shaft or axis is formed more of phosphate than carbonate of lime, and is therefore allied to bone in its consistence. It is movable at both ends, and is covered with a cœnosarc, which is prolonged on each side into branches, having a general resemblance to the "barbs" of a feather, and upon these delicate offshoots the polyps are seen, placed in the upper margin of each. These barbs are supported by a large number of calcareous spiculæ in their interior. 
The British species ( $P$. phosphorea) is very common on our coasts, especially in Scotland, and is taken in numbers attached to the bait of the fishermen's lines, especially, according to Ellis, when this bait is a mussel. It is from two to four inches long, and of a purplo colour, except at each extremity, where it is pale orange. When irritated it is beautifully phosphorescent. A difference of opinion exists among naturalists, whether the Sea-Pen is permanently fixed in the ground, or has a certain extent of locomotion. Grant, after Cuvier, Pallas, and Bohadsch, has adopted the latter view, and expresses himself about it as follows: "A more singular and beautiful spectacle could scarcely be conceived than that of a deep purple $P$. phosphorea, with all its delicate transparent polypi extended, and emitting their usual brilliant phosphorescent light, sailing through the still and dark abyss, by the regular and synchronous pulsations of the minute fringed arms of the whole polypi."'

Dr. Johnston, however, in his British Zoophytes, doubts whether the Sea-Pens have any locomotion, and quotes Lamarck and Schweigger as authorities in his favour. Johnston, with much reason, observes, that it is most improbable that a compound animal so low in the scale should have the power of locomotion, and states that he has never known them to move their position when placed in a basin of water. "They inflate the body until it becomes in a considerable degree transparent, and only streaked with uninterrupted lines of red; they distend it more at one place, and contract it at another; they spread out the pinnæ, and the polyps expand their tentacles, but still they never attempt to swim or perforn any effort towards locomotion. Our fishermen believe that they are fixed at the bottom with their ends immersed in the mud, and the paleness of the base, when viowed in connection with the preceding observations, go far, in my opinion, to provo this statement to be correct."

The phosphorescence of the Sea-Pen proceeds entirely from the polyps. Fig. 165 (frontispiece) is ono of these polyps magnified.

Another of what are sometimes called bark-covered Corals is illustrated in the plate by a figure of the well-known red Coral of commereo (Fig. 162, frontispieco), which is produced by an Alcyonarian polyp belonging to the genus Corallium. A portion of the conosare and its polyps have been remored in three places in the figure, and what is seen laid bare is the bony, calcareous, richly and variodly-coloured substance of which coral ornaments are formed. This Coral is fomm principally in the Moditerranean. where it forms one of the staple articlis of maritime industry. The somewhat clumsy-looking form in which it grows, as seen in 
the plate, is a necessity of its existence, for the Coral is itself brittle, and were the branches thinner they would inevitably be broken by the waves. Observe that the exposed parts show no pits or depression - the surface being perfectly smooth. The conosare is whitish in colour, and the polyps are milk white, and nearly transparent. Its growth is slow-it seldom is longer than one foot, and this requires six or seven years to reach.

The best Coral is found in the shallowest waters; but it is found as deep as 100 fathoms. Its ratio of growth is that of its depth. Thus, it will increase in size a foot in eight years, in shallow water, with a hot sun; but it will take thirty years to reach that size at 100 fathoms. It varies in colour from yellow to a rich red. Dealers recognise at least a dozen varieties. The hardest and most brilliant in colour being the most prized. The same ground in the Coral fisheries, as they are termed, is only dredged once in ten years, and then in the rudest manner, by dragging a net over the bottom, and thus getting what they can.

Still another Alcyonarian polyp demands our attention. It is that which forms the beautiful "Organ Pipe" Coral, a figure of which is seen at Fig. 161 (frontispiece). There is a peculiarity about this form, which leads us to the next group, inasmuch as although it is one of the Alcyonaria, with eight tentacles, yet the corallite is secreted upon the "tissue" or "sclero-dermic" plan, while all the others of the family form their skeletons upon the "foot" or "sclero-basic" system.

We shall see that the first group of Corals, including all the reef builders, secrete their skeletons on to former plan.

The "Organ Pipe" is a very inter-

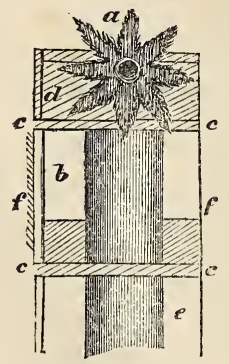
esting Coral. Only the polyps in the top platform, as seen in the figure, are alive-as, in fact, I have before noticed is the case in all Corals. The polyp here has partially the power of withdrawing itself into a calcareous tube-hence the name of the genusTubipora. They are of a beautiful grass-green or violet colour, which contrasts finely with the rich bright crimson red of the Coral. Its mode

Fig. 172.-Single tube and polyp of Organ of reproduction is characteristic and
Pipe Coral.- $a$, polyp- $b$, tabe with live polyp-c c c c c, edges of platforms cut sufficiently curious to merit a short away in section-d, platiorm- $e$, dead description. Fig. 172 represents an
tube- $f f$, walls of next tube. enlarged figure of one of the tubes and its polyp. Fig. 161 (frontispiece). The polyp $(a)$ is shown partially 
extended from the tube $(b)$, which contains the rest of its body and the germs of the future race of polyps, and it is able to protrude from or draw into the tube by the contraction or relaxation of a peculiar musculo-membranous structure. Now, where the polyps have built up their tubes to say about the point $c$ (Fig. 172), they simultaneously throw out a lateral process of lime-secreting cœnosarc, which processes, uniting together and becoming calcified, constitute the platform ( $d$, Fig. 172). Having effected this object, one or more of the germs of each polyp become attached to the platform, grow up, and, when they have arrived at the same height as their now dead parents, they, like them, throw out lateral processes, form platforms, and increase and multiply. Each stage, therefore, represents a generation of polyps, the uppermost only being alive.

So much for the Alcyonarian polyps with their eight tentacles, and, for the most part, "foot" or "base" secreted skeletons.

We will now turn to the Zoantharia, the polyp of which has five or six tentacles, or multiples of those numbers, usually six, and whose skeleton is built up upon the "tissue" or "sclero-dermic" system.

'This division comprises the great number of Corals in the families Madreporidæ, Fungidæ, Poritidæ, Astræidæ, Milleporidæ, \&c., and with which I shall make the reader acquainted by a short notice of the figures in the frontispiece.

Another passage of the "Alcyonarian" to what has been well termed the "Lamellarian" Corals, is effected by the clove-like form known as Caryophyllia (Figs. 168-171, frontispiece).

In these Corals the single polyp lives at the extremity of the dead stony mass, and is able to retract itself within the cup-like extremity (Fig. 168). When the polyp dies, its successor forms a new cup for itself over that of its dead parent, and then the calcareous structure increases in length. Sometimes it is single, and at others it assumes a dendritic or arborescent form (Fig. 171, frontispiece). Sometimes the external surface is smooth (Fig. 168, frontispiece), or pitted, as shown in the allied genus Pocillopores (Fig. 160, frontispiece).

In other instances, each cell is markod by a rim or circular indentation, with longitudinal raised stria between each, as is seen in the well-known form (Fig. 171, frontispiece). In all cases. however, the singlo large sea-anemone, like polyp, lives alone at the end, and its eup-like skeleton is divided into partitions of six, twelse, twentyfour, sce, so that when the living polyp is remored a calcarcous lamellated struture of this kind is seen. In Fungia (Fig. 1 (i3. frontispiece), each polyp enjoying a separate existence only forms a single structure. the well linown mushroom-shaped Corals of our collections. Althugh I hatr represented in the figure a group of 
these Fungix, each corallum is separate. It is reproduced by buds or gemmules, each of which grows to a certain size, is then detached, and becomes a free separate being, and forms its own corallum, as "its fathers did before it." Now, were we to take a number of Caryophilliæ, and place them close together, we should form a well-known Coral called Astræa, as seen at Fig. 157 (frontispiece), with little or no stony substance or cœnenchyma between the cells; but as some of the family like to live at a respectful distance from each other, the cœnosarc secretes a cœnenchyma, as seen at Fig. 167 (frontispiece).

Now it will be seen how easily and usefully our hard words step in.

Again, suppose that instead of having separate and distinct star-like cups, as seen in Fig. 157 (frontispiece), each star was to become confluent or join with its neighbour, we should then have the appearance actually seen in the well-known "Brainstone Coral," of which a figure of my specimen from Bermuda is seen at Fig. 152 (frontispiece). Of portable species this is among the largest, though they are said to attain to six feet in diameter in the Red Sea.

At Figs. 155, 169, 158, and 159 (frontispiece), we have examples of some of the common species of Madrepore, in which the cells are observed to stand out in prominent relief. In Figs. 166 and 156 (frontispiece), the cells are noticed to be, as it were, sunk in the calcareous mass of Coral.

These last six species are among those most frequently found in coral reefs, where we shall follow them in our next chapter.

\section{H A P T E R IX.}

\section{On Coral Islands.}

CoRAL Islands and reefs are among the most interesting and remarkable features on the surface of the earth, and in the natural history of the world.

Take a map of the great Pacific Ocean, and mark out a space from the island of Ducie, somewhere about $120^{\circ}$ of W. longitude, to the Pellew Islands, on the line which strikes $135^{\circ} \mathrm{E}$. of Greenwich. Your eye will run over a great group of islands occupying a space $15^{\circ}$ north and $30^{\circ}$ south of the equator. The space thus marked out is upwards of sixteen millions of square miles, and, with the exception of part of New Holland and New Guinea, all the islands over which your eye will pass have been formed 
into their present shape by the Coral polyp. This statement is not invalidated but supported by the theory held by some, that these islands are the high peaks of a vast continent gradually sinking into the depths of the sea. If this be true, it involves a previous sinking and a subsequent upheaving, for while all of them are more or less surrounded by reefs, many are formed even to their tops of dead Coral alone. That they are now sinking, I believe there is no doubt; and the beautiful and generally accepted theory of Mr. Darwin, of the mode by which they were built up, is entirely based upon this fact. The mind is startled when it contemplates the immensity of time which has passed away since the Coral Islands were first formed on the rising continent, and after its history in timo, the reefs and lagoons were formed by the same little polyps as it gradually sank again into the unknown depths of the sea. I shall allude to this subject again, but I may remark that no facts in science are better known, and no generalisations more unanswerable than those connected with the formation of coral structures in time and space.

In the meantime, let us examine the interesting question, so ably treated by Mr. Darwin, of the modus operandi by which Coral Islands and reefs are formed.

These islands and reefs are found in the great coral regions in three or four different forms. First, we have islands in mid ocean, with a lake in their centre; these are called "lagoon islands." Secondly, we have islands formed entirely of dead Coral. Thirdly, we have living coral reefs surrounding an island or bordering a continent, quite in shore, with a small space of still water between the reef and the shore; these are termed "fringing reefs." Then, fourthly, these reefs are at a greater distance from land, leaving a large space of still water between them and the shore; these are termed "barrier reefs."

Now, before the publication of Mr. Darwin's work on the "Structure and Distribution of Coral Reefs," in 18.12, we had no intelligible theory to explain the formation of these reefs. I will briefly detail this theory, referring those who wish for further information to the admirable little book above mentioned.

The two essential facts upon which the theory is built up are, first, that the wholo of the limi comprising what are known as the South Pacific Islands and the continents hordering thereon, are at the present time, and havo been for ages past, gradually sinking; secondly, that the Coral polyps do not live at greater depths than between twenty and thirty fathoms-Agassiz says from twelve to fourteon fathons.

Both of these positions lase been ably argued by Mr. Darwin, and 
have been unchallenged for the last twenty-five years. Now upon the above data, of which I will say more presently, Mr. Darwin accounts for reef formations thus :

Suppose $a$ (Fig. 173) to be a section of a mountain portion of high land, which is in a state of temporary quiescence, neither subsiding nor rising, and that $b$ is a coral reef, which has gradually been formed by our friends the polyps. Now let us suppose, what is in fact a frequent occurrence in the Pacific, that an active volcano opens in the summit of $a$, as seen in the sectional diagram at Fig. 174. Simultaneously with this active volcanic action, it accords

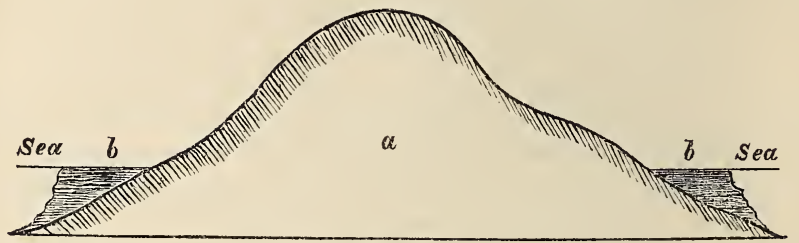

Fig. 173.

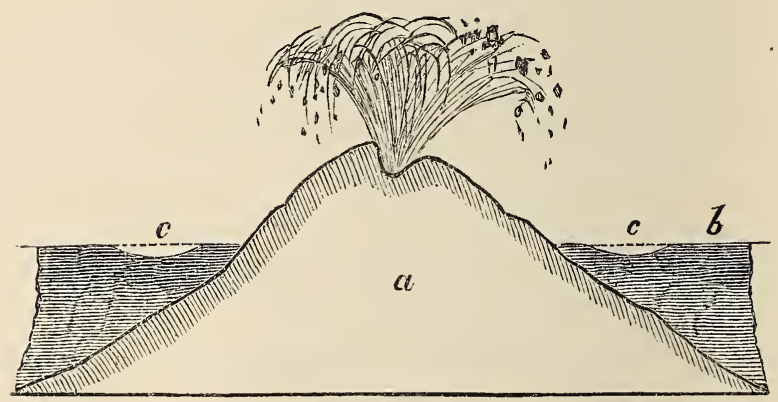

Fig. 174.

with experience that the mountain would begin to subside, and as it did so the coral reef begun at $b$ (Fig. 153), would continue to rise as the polyps-which only live from twelve to thirty fathoms deep, and never above low water-would keep adding to their wall just in proportion as the land sank. Now the polyps for many reasons thrive best outside the reef. They are, in fact, every now and then destroyed between the inner boundary of the reef and the shore, and the consequence is that the outside of the reef gets to be the highest, and what is called a lagoon channel is formed between this front and the shore, as seen in Fig. $174(c)$. This lagoon is more or less 
deep, but generally there is enough water to admit ships of all sizes. This constitutes what is called a "fringing reef," the best examples of which are found at the Salomon Isles, the New Hebrides, the Friendly and Navigator's Islands in the Pacific, and at Sumatra, Nicobar, Ceylon, Mauritius, Madagascar, and the African coast in the Indian Ocean.

Now let us imagine this fringing reef to be a coral wall surrounding the island, and covered with living polyps to the bottom of the lagoon channel on one side, and from twelve to twenty fathoms on the other. And let us further suppose that a sudden sinking, of say six feet, took place; the immediate effect of this would be first to kill all the polyps on the sea-side below thirty fathoms; and supposing the coral wall on the other hand to be built up six feet suddenly; it is quite clear that, as the side of the mountain $(a)$

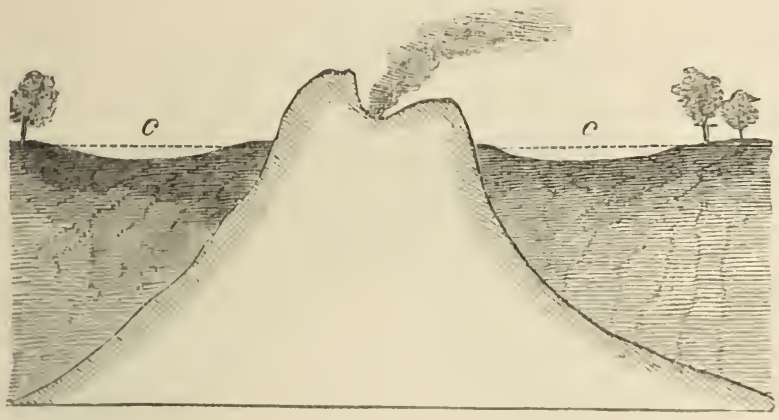

Fig. 175.

slopes considerably to the sea, by the above imaginary movement the coral wall would be removed further from the shore, and the lagoon channel would become wider. Now what I have supposed might take place suddenly does actually occur slowly, and the result of this subsidence of the land and the now languishing volcano is to convert a "fringing" into what is known as a "barrier reef," as seen in Fig. 175. The reef is still farther removed from the shore, and tho lagoon channel widens, as seen at Tahiti, Fidji, New Caledonia, New Ireland, Oualan, Louisade, and the west const of New Guinea, and a largo extent of coast from near Capo Sunday to Torres Straits in the N.W. of Now South Wales.

Barrier reefs are also found surounding the Cormoro Islands in the Indian Ocean and both sides of the shores of the Red Sea, from $160^{\circ}$ to $21^{\circ} \mathrm{N}$. lat., occupying nearly the middle of the coasts of that 
singular sea, while fringing reefs, as before mentioned, are found at each end.

But in some instances, though rare, these "barrier reefs" appear as circles of land covered with trees and vegetation. Mr. Darwin explains this by the fact that floating masses of vegetable matter are caught by, and entangled in, the uppermost ridge of the coral wall. The Coral thus killed at the surface breaks up, and, mingling with the extraneous matter, forms the basis of a soil in which the seeds of the cocoa or other trees take root and grow, forming a wall of vegetation round the island, as seen in that of Bolabola, of which Mr. Darwin gives a sketch.

It is very rare, however, that the whole of the upper part of the reef, as in this instance, is converted into land. More frequently, as would be supposed, and in accordance with the theory of their for-

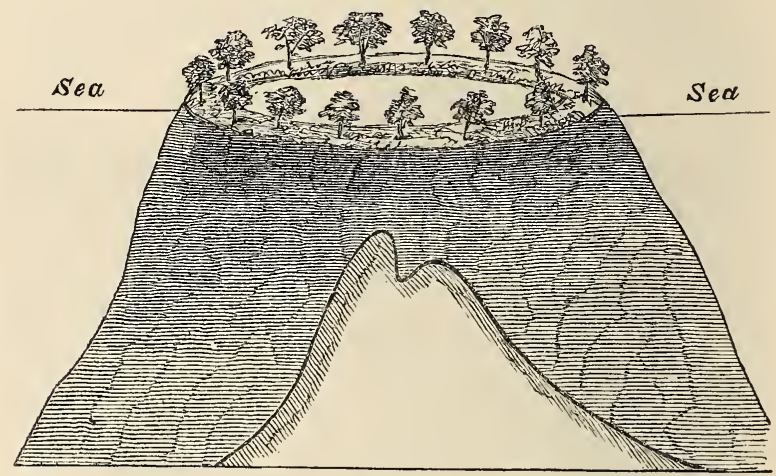

Fig. 176.

mation, the land appears as a series of small islets, with smooth water channels between them, through which ships pass from the stormy sea into the quiet and lovely oasis within the reef.

Now let us imagine the process of sinking to go on as before, until the top of the mountain has gone below the surface of the sea; and at the same time let us suppose the top of the coral wall to have been, as in the case of the "barrier reef," partially converted into land. We shall then have an "atoll," or "lagoon island," as shown in the diagram 176, and actually seen in the Low and Caroline Archipelagos, and in the majority of islands in the Pacific; in the Saya de Maeha, Cosmoledo, Chagos, Maldivas, Laccadives, and Keeling Island in the Indian Ocean, and the Paraceles, \&c., in the China Sea. 
Now remember that in the whole district of coral formation in the Pacific, there are numerous active and many extinct volcanoes. It is part of Mr. Darwin's theory that the mountain which has sunk in the middle of the lagoon island was, when surrounded by the "fringing reef," an active volcano, as shown in the diagram; and it is a strikingly confirmatory fact that the known active volcanoes are all in islands or coastland which have "fringing reefs." When its activity was exhausted it began to subside, as seen in the diagrams.

It is quite true that Mr. Darwin's theory implies that the base of the coral belt round the lagoon shall be at an enormous depth; and in many instances quoted by him this is actually the case. But after a time the subsidence ceases. How long the submerged mountain remains quiescent is not known; but that a subsequent upheaving takes place is proved by the fact that many of the South Sea Islands are entirely formed of Coral, from top to bottom. Somo of them are quite recent, and from $80 \mathrm{ft}$. to $200 \mathrm{ft}$. high, and can only be accounted for by what I may term the indisputable fact that they have been upheaved from the sea after the Coral polyp had for ages been building up its reefs thereon. Great facts in confirmation of this sinking and submergence of large tracts of land and mountains are well known to geologists. Marine strata are found at the top of the Alps at $800 \mathrm{ft}$. from the sea-level; on the Pyrenees at 10,000ft.; on the Andes at 15,000ft.; and on the great chain of Himalayas at 18,000ft. Now, unless these mountains had been raised up from the ocean, we must believe the ridiculous alternative that the sea-level has subsided $18,000 \mathrm{ft}$. !

On this subject, and the causes which operate in the rising and sinking of the earth, and the proofs that both are in constant operation, I must refer to "Principles of Geology," by Sir C. Lyell, where the subject is handled with great ability and research.

But there is still a very interesting question among the many connected with coral reefs, about which I must offer a few remarks - the rate of growth, and the known age of those now living, or which have been formed during recent times.

On this subject wo havo most interesting data furnished by Professor Agassiz, in the researches upon which he has founded a beautiful series of deductions as to the formation of the peninsula of Florida. By actual experiment ho determined that in the period of fourteen years the crust of Coral formed on the new foundation of Fort Taylor, at Key West, and Fort Jefferson, on tho Tortugas Islands, did not exceed one inch. But as branching Corals only occupy half the spaen they cover. Professor Agassiz considers that the real rate of growth does not exceed half an inch in fourteon 
years; although, to allow the most liberal scale in his calculations, he sets it down as one foot in a century. I may here remark, however, that Mr. Darwin states that a channel made with crowbars through the reefs round Keeling Island, according to the authority of Mr. Liesk, only ten years before, was at his visit so blocked up with living Coral that ships could not enter. Mr. Darwin also relates experiments conducted by Dr. Allen, of Forres, on the east coast of Madagascar, who placed twenty Corals on a sand bank in three feet of water (low tide), and in the July following each had nearly reached the surface, and was quite immovable. Mr. Scutchbury also relates, in the West of England Journal, vol. i. p. 50, that an oyster, only two years old, had attached to it a Coral, one of the Agarica, which weighed $2 \mathrm{lb} .9 \mathrm{oz}$. There is no doubt, however, that the rate of growth varies with the species, and as Professor Agassiz was well aware of the instance I have cited, as well as the deduction of Mr. Dana from data supplied him by Sir J. G. Dalyell, on the growth of Actinia-viz., that the polyp of the Coral Madrepore increased three inches per annum, I presume he was well satisfied with the correctness of his own experiments, and of the deductions drawn from them. These deductions are the following:

Beyond the mainland of the extremity of the peninsula of Florida are a series of islands known as the "Keys," and of these "Key West" is the most western. Outside these "Keys," and rising just above and resting upon the Florida living reef, are a series of small scattered islands. Now, mark that I have said, "living reef." In fact, the Corals are alive from the surface of the water to the depth of $60 \mathrm{ft}$. Professor Agassiz places the limit of polyp life much less deep than Mr. Darwin, as he says there is no proof that the creature can live below twelve fathoms.

Calculating, therefore, that the Florida reef is sixty feet deep, and that it has been built up at the rate of twelve inches in a century, Professor Agassiz considers that this reef must have been six thousand years in reaching its present height, and that the island outside the "Keys" must have taken this time to form.

On examining the "Keys" themselves, Professor Agassiz found that they were nothing more than reefs which had been built up before the outer reef began to form. Soundings gave the same depth of $60 \mathrm{ft}$., and the only difference between the inner reef and the outer was that the crests of the former had been broken by the action of the tides and storms. He then calculated that the age of this old reef was 12,000 years, and he calls this the second item in his calculation.

Now the "Keys" are separated from the shore by "mud flats," 
in which there is rarely more than a few fathoms of water, most of which is uncovered at low tide. The shore itself is made up of "bluffs" rarely more than ten feet high. North of the shore come what are called Indian hunting grounds, "low, flat, marshy ponds, hardly above the level of the sea;" and still further up country are another series of what are called "hummocks," which are "little hilly tracts of land from five feet to ten feet above the level of the sea, strangely arrayed in a row."

To make a long story short, Professor Agassiz discovered that these bluffs of the shore, and the "hummocks" beyond them, were severally the remains of coral reefs similar to that on which the "Keys" are formed, and that which is just completed three miles beyond it! They have the same average thickness, and have been built up by polyps specifically the same as those now living. Therefore, says Professor Agassiz, we have evidence that "twenty-four thousand years ago there was a sea washing the place where these 'hummocks' are, and that no reef had then formed beneath them." But still more. It appears that the space occupied by the four reefs described covers only sixteen miles, but that similar concentrically placed "hummocks" exist as far as Lake Okeechobee, sixty miles in the interior. "We shrink," says Professor Agassiz, "even from the evidence that it has required 24,000 years to build this narrow strip of land; how shall we shrink from the assumption that hundreds of thousands of years must have been required to build that prolongation of the peninsula of Florida, which is entirely made up of coral reefs? And yet what is that compared with the age of the world ? It is to-day! It is modern time! It is the period called the present, for it is a period within which the species of animals which now live began to exist on the earth."

Such is the famous "Florida reef" induction-one of the latest scientific investigations into the age of that world which was truly "made in the beginning," and perfected for the success and maintenance of each successive race of beings, which we know full well from the unerring records of geology have successively inhabited it.

I have not noticed the beauty of the scenery, nor the lovely climate, nor the natural productions, nor the wild sarages, nor the still wilder storms, which aro characteristic of the Coral Islands in the Pacific Ocean. In Mr. Fllis's interesting "Polynesian Researches" much information on this subject will bo found.

Of the other two divisions of the Actinozon, viz.. the Rugosa, the species of which are all fossil, and the Ctenophora, which are all oceanic, a good deal that is interesting might be said; but their consideration is of more importance to the purely-scientific man, and I will, therefore, end here my "Popular Illustrations" of the Colenterata. 
The reader who wishes to know more about the sub-kingdoms treated of in this volume will do well to consult the "Icones Histiologicæ" of Kolliker; Professor Greene's work on the Protozoa and Cœlenterata; Professor Huxley's "Elements of Comparative Anatomy;" and Professor Owen's Lectures on the Invertebrata. 


\section{N D E X.}

Animal fibrino, 6

Azote, 6

Air cells, 12

Atmosphere, 14

Anther, 17

Albumen, 17

Annulosa, 19

Algæo, 20, 38

Animalcule, 24

Allman, Profossor, 27, 33

Acineta, stage of, Vorticellinæe, 32

Acinota, germs of, 33

Amooba, 34

Agassiz, Profossor, 34, 127

Arcella, 38, 39

Azoic, 50

Acanthostaurus hastatus, 62

Acanthostaurus purpurascens, 62

Actinozoa, 70, 105

Antonnularia antonnina, Fig. of, 82

Aněmōme, sea, 109

Alcyonaria, 112

Astrwa, 122

\section{BALFOUR, Profossor, 13}

Balsam, 13

Bary, M., 24

Balbiani, 29

Bennett, Profossor, 31

Boworlank, Mr., 33

Buale, Mr., 33

Bulimina pupoides, Fig. of, 12

Bonnott, Mr., 87

Brainstone Coral, 122

Cotxt.einon, 4, 10

Cauliclo, 5

Chlorine, 5

Carbou, 5

Cascino, 6

(oll, 8

Crystal, 11
Chlorophylle, 12

Carbonic acid, 2, 14

Carpenter, Dr., 15, 33, 34, 36, 41

Corolla, 17

Confervar, 20

Cyst-membrane, 24

Cystodia, 24

Cilia, 26

Cortical layer, 27

Cuticula, 27

Contractile chambers, 28

Contractile tissue, 31

Contractile filament, 31

Contractile vesicle, 32

Claparède and Lachmann, 36,37

Chitine, 38

Cristellaria calcar, Fig. of, 42

Cornu ammonis, 43

Cambrian lower rocks, 48

Carboniferous rocks, 49

Coolenterata, 69

Corynidio, 77

Campanularia verticillata, Fig. of, 82

Calycophoridw, 84

Coonosarc, 85

Chrysaora hysoscella, 97

Coral, 111

Corallite-corallum, 113-11:

Cononchyma, 113

Corallium (gonus), 119

Caryophyllian 121

Coral islunds, 12:2

Ctonophorn, 129

Diastastin 6

Diatomacea, 20

Dufour, Dr., 21

Difllugia, 38

D'Orbigny, 41

Dontalima logumon, Fig. of, 4 ?

Diacortima globularia, Fig. of, t3

Devouian rook, 1!) 
Diphyes dispar, Fig. of, 84

Darwin, Mr., 123

\section{EmbRYo, 3}

Endocarp, 3

Exogenous growth, 7

Endogenous growth, 7

Epiblema, 8

Endosmosis, 9

Exosmosis, 9

Epidermis, 13

Exhalation, 15

Euplotes, 25

Ehrenberg, 28, 58

Entosolenia squamosa, Fig. of, 42

Eozoic, 50

Eozoön Canadense, 51

Eocene, 55

Eucecryphalus Schultzei, Fig. of, 60

Ellis, Mr., 75

Eschscholtz, 88

Endoderm, 107

Ectoderm, 107

Funn, 10

Filament, 17

Fission, 32

Foraminifera, 34-40, et passim

Fusulina, Fig. of, 53

Fishes in crust of earth, 53

Fungia, 121

Florida reef, 127

Germination, 3

Growth, 4

Gluten, 5

Gliadine, 6

Goadby, Mr., 13

Granules, 17

Gregarina, 20, 22, 29

Greville, Dr., 31

Grant, Dr., 24, 64

Gullet, 31

Greene, the late Professor, 33

Gromia, 39

Globigerina bulloides, Fig. of, 42

Henslow, Professor, 3

Hydrogen, 4, 5

Heat, 4

Hnxley, Professor, 33, 58

Hopkins, Mr., 49

Huron Lake, 51

Haughton, Professor, 55
Heliosphcora inermis, Fig. of, 61

Hydrozoa, 69

Hydra, 71

Hermia glandulosa, Fig. of, 74

Hydrosoma, 78

Hydrothecæ, 78

Hydrorhiza, 78

Hydræcium, 84

Hydrozoa, reproduction of, 101

INTERNODE, 10

Instinct, 11

Iron, 5

Infusoria, 20

Icones Histiologicæ, 21, 28

Kolliker, Professor, 21, 28

LIFE, 3

Lime, 5

Leaves, 12,14

Laticiferous vessels, 14

Latex, 14

Loxodes, 25

Lieberkühnia Wageneri, 37

Lagena vulgaris, Fig. of, 42

Lagena interrupta, Fig. of, 42

Lagynis Baltica, Fig. of, 46

Laurentian rocks, 49

Laomedea gelatinosa, Fig. of, 79

Lucernaridæ, 99

Lucernaria campanulata, Fig. of, 99

MoLECULAR matter, 5

Magnesium, 5

Micropyle, 17

Mollusca, 19

Mycetozoa, 24

Motion of animalcules, 36

Miliola bicornis, Fig. of, 42

Miliola tenera, Fig. of, 43

Mackay, Mr., 48

Murchison, Sir Roderick, 48

Mammals in crust of earth, 53

Miocene, 55

Medusidæ, 92

Medusa, Fig. of, 95

Madrepores, 122

NuCleUs, $5,28,32$

Nitrogen, 5

Node, 10

Nitric acid, 10

Nucleolus, 28, 32 
Nodosaria radicula, Fig. of, 42

Nodosaria pyrula, Fig. of, 42

Nonionina Barleeana, Fig. of, 42

Nonionina Jeffreysii, Fig. of, 42

Nonionina elegans, Fig. of, 42

Neozoic, 50

Nummulitos, $53,55,58$

Nectosac, 84

Nectocalyx, 84

Oxyaen, 4, 5

Ovary, 17

Orbulina universa, Fig. of, 42

Orbitolitos, Fig. of, 46

Oldhamia antiqua, 48

Ova, 108

Organ-Pipe Coral, 120

Protopiryton, 1, 2

Protozoon, 1, 2, 19

Pericarp, 3

Pollen grain, 4

Plumule, 5, 10

Phosphorus, 5

Potassium, 5

Physical force, 11

Petiole, 12

Pigment colls, 13

Pistil, 17

Protozoa, 19

Pouchet, M., 24

Pastour, M., 24

Pritchard, Dr., 25

Paramacium, 25, 26, 29

Polygastrica, 26

Peristome, 31

Podophorya, 33

Protous, 3t

Podostoma, 36

Protoplasm, 36

Psondoporlia, 39, el passim

Polystomolla crispa, Fig. of, 42

Permian strata, 49

Palouzoic, Uppor and Lower, 49, 50

Pyrmidls, Tho, 55

Pliocene, 55

Physomatium Miillori, Fig. of, 63

Plumularia piunata, Fig. of, 82

Pliysophorida, 86

Phymalia Polagien, 86

P'liysalin Caravolla, 87

Phymalia utriculus, 88, 90, Fig.

Pnoumatophore, 89

Pnoumatocyst, 91
Portuguese man-of-war, 91

Pelagia cyanea, Fig. of, 93

Phosphorescence of the sea, 99

Pennatula grisea, 118

Pocillopores, 121

RAdicLe, 5, 8, 9

Reason, 11

Ranunculus aquaticus, Fig. of, 13

Respiration, 15

Radiata, 19

Radiolaria, 20, 58

Rotatoria, 25

Rhizopoda, 33

Reticularia, 37

Rotalina concamerata, Fig. of, 42

Rotalina concamerata (jun.), Fig. of, 42

Rotalia, 53

Reptiles in crust of earth, 53

Rhizostoma Cuvieri, Fig. of, 94

Rugosa, 129

SEED, 4

Starch, 5, 20

Sodium, 5

Silica, 5

Sulphur, 5

Sugar (grape), 5, 17

Spongioles, 8, 14

Stom, 10

Silicic acid, 10

Stomata, 13

Stamens, 17

Stigma, 17

Stylo, 17

Sponges, 20

Stentor, 25

Sarcodo, 26, 38

Stoin, 29

Spirilina aronacon, Fig. of, 42

Scliultze, Dr., 43

Silurian, upper and lower rocks, 49

Strabo on Nummulite, 55

Sponges, 63

Spiculas of Spongos, 66

Somatic cavity, 75

Sortularida, 75

Sortuluria polyzonias, Fig. of, 81

Somatocyst, 8t

Sicloro-basic, 111

Seloro-dermic, 111

Truit, Dr., 21

Trichooyuts, 27

Textularia rariabilis, Fig. of, 42 
Textularia difformis, Fig. of, 42

Tchihatcheff, M., 55

Thalassicolla, 59

Thalassicolla pelagica, Fig. of, 60

Trembley, 73

Tubularia indivisa, Fig. of, 74

Thoa halecina, Fig. of, 81

Thuiaria thuia, Fig. of, 81

Uvigarina PYGMaAa, Fig. of, 42

Vital force, 2, 11, 17

Vegetable fibrine, 6

Vascular vessels, 13

Vertebrata, 19
Volvox globator, $20,25,26$

Vorticella nebulifera, 25, 32

Vestibulum, 31

WheAT, 2

Watson, Bishop, 15

Wright, Dr., 33

Williamson, Dr., 41, 47

Wallich, Dr., 41

Willsia stellata, Fig. of, 96

YEAST, 6

ZOOPHYTES, 76

Zoantharia, 111 


$$
\text { . }
$$



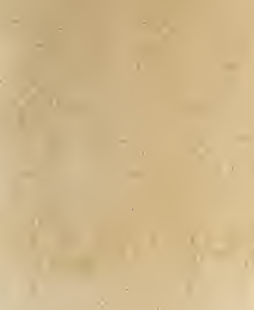

.

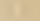

1

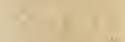




$$
\% / e
$$



IVORKS PUBLISHED BY HORACE C'OX,

346, Strand, W.C.

In small 8vo, cloth gilt, price 3s. fid.,

THHE RIVER'S SIDE; or, the 'Trout and Grayling, and How to Take Them.

By Sir RANDAL ROBERTS, Bart.

In post $8 \mathrm{ro}$, cloth, price $2 s$.,

A TREATISE on HARNESS, SADDLES, and BRIDLES: their History $A$ and Manufacture, from the earliest times down to the present period. By A. DAVIS.

In post 4 to, price $1 s .6 d$; by post, 1 s. $8 d$.

'JIIE ANGLER'S DIARY and FISUERMAN'S GUIDE to the Rivers and Lakes of the World; to which is added forms for rogistering the description, weight, \&c., of the fish caught during 1868. The List of Fishing Stations has been greatly enlarged and carefully revised.

In post 4 to, price $1 s$. ; in cloth, $1 s .6 d$; by post, $1 s .2 d$. and $1 s .8 d$., 'THE SHOOTER'S DIARY; or, Forms for Registering Game Killed during

These forms can bo used either to show the amount of game killed by the individual sportsman or the total produce of a manor, or both together, and aro, therefore, ospecially valuablo to sportsmen and gamo preserver's. A Debit and Credit account is also added, which shows at a glance the absolute cost of a shooting. $\Lambda$ List of some of the Principal Shooting Stations throughout the World is also given.

In post 8 vo,

'JHE RAIL AND THE ROD; or, the Tourist-Angler's Guide to Waters 1 and Quarter's 'Thirty Miles round London By GREVILLE FENNELL.

No. 1. The Great Eastern Railway. Price 1s., cloth 1s. $6 d$.

No. 2. The Great Westorn Railway. Price 1s., cloth $1 s .6 d$.

No. 3. The South-Western Railway. Price 1s., cloth $1 s .6 d$.

Or the three bound together, cloth gilt, $4 s$.

\section{Prico 6s. 6d.,}

'JHE LAWS rolating to SALION FISHING in GREAT BRITAIN; including the Statntes passod during the last Session of Parliament for England and Scotland, and the whole of the Scotch Bye-laws. By THOMAS BAKER, Esi., of the Inner Temple, Barrister-at-Law, of the Salmon Fisheries Oftice, Author of tho "Laws relating to Public Healtb," the "Laws relating to Burials," \&ee, se.

" $\Lambda$ Digest of this and the $\Lambda$ ct of 1861 las been carefully preparod by $\mathbf{M r}$. Baker, the Socretary to the lishery Otlico, and has been publishod; it will be found very useful to Boards of Consorvitors, IIagistratos, and all who aro interestod and tako an activo part in fishery preservation." - Mr. Fiennells

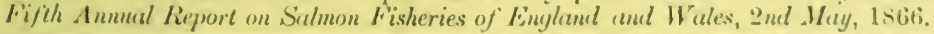

Now and Rovised Edition, in crown svo, illnstratod witl Diagrams, fic., prico (icl.; cloth 1.s., post-froe ld. extra.

CROQUE'T; its Laws and Imploments. By a COMMITEE of PLAIVERS seloctod by the Eilitor of "The Fivld."
' II F FIF, I,

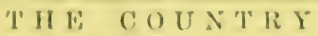
G F N T I, F I I N S
N E WS P P P R.

This Journal, of world-wide famo and circulation,

contrins original intolligenco on

Hunting, Shooting, Angling, tho Turf, Conrsing, Yachting, Cricket, Whist, Chess, tho Comutry Honse, the Farm, the Garden, Sports in all

parts of the World, Natural History, Se., siv..

with tho Advertisements on all subjouts commetod therewith.

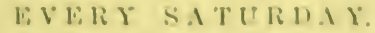

A copy in moturn for vight postago stomps.

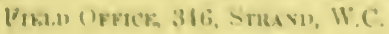




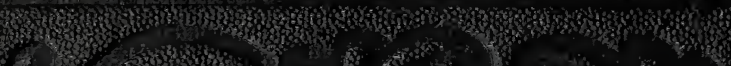

等

Wes is 